\title{
STUDENTI Z ÚZEMÍ POLSKO-LITEVSKÉ UNIE NA PRAŽSKÉ UNIVERZITĚ V 17.-18. STOLETÍ
}

\author{
ROBERT T. TOMCZAK
}

\section{STUDENTS FROM THE POLISH-LITHUANIAN COMMONWEALTH (RZECZPOSPOLITA) AT THE PRAGUE UNIVERSITY IN THE $17^{\text {TH }}$ AND $18^{\text {TH }}$ CENTURY}

This contribution deals with young men from the Polish-Lithuanian Commonwealth at the Prague University. In the $17^{\text {th }}$ and $18^{\text {th }}$ century, approximately one hundred students from the Polish-Lithuanian Commonwealth, i.e., Crown of the Kingdom of Poland, Lithuania, Royal Prussia, and the Duchy of Prussia (until 1657), had passed through its lecture halls and their names are recorded in the relevant sources (student registries, albums, and printed university documents). These young men were either of aristocratic $(40 \%)$ or bourgeois $(51 \%)$ origin. Within the intellectual context of Early Modern Europe, the Prague University was seen as one of the conservative and provincial establishments. Even so, it managed to attract Polish students by its tradition, its Catholic nature, geographic location (travelling to a nearby country was cheaper), but also lower costs of study and lower living expenses. These were the main considerations which led the young Poles to choose Prague academic environment as the place where they would receive their education. The Prague University was affordable even for poorer nobility and burghers, which formed the majority of Polish students in Prague.

Keywords: Polish-Lithuanian Commonwealth - students - Prague - university $-17^{\text {th }}$ and $18^{\text {th }}$ century - prosopography - educational travel

Touha po vědění, pramenící z lidské přirozenosti, kterou tak silně zdůrazňoval Aristoteles ve své Metafyzice, charakterizuje dějiny lidstva od jejich samotných počátků. Zprvu vyplývala z čistě akcidentálního poznávání okolní reality, aby se zanedlouho z výrazně neoficiálního stylu přetvořila ve formalizovanou podobu výchovy; je tedy spojena se vznikem různého typu škol a osvětově-výchovných institucí, jejichž hlavním úkolem bylo postavit proti ideálu vita voluntaria (rozkošnický život, charakteristický pro nevzdělanou a primitivní společnost, jejímž cílem je pouze slepé užívání si života) ideál vita activa, respektive vita contemplativa (rezignace na pozemské záležitosti a obrácení se k poznání a k vnitřnímu sebezdokonalování).

Jedinci, které oslovovaly tyto ideály, se zapojovali do procesu nabývání vědomostí získáváním stále vyšších klasifikačních stupňů ve školském systému, jehož kulminací bylo studium na různém typu akademií nebo univerzit. Ve starověku to bylo ztíženo výrazně elitním charakterem vyššího vzdělání. Středověk přinesl novou kvalitu v podobě intelektuálního oživení na přelomu 11. a 12. století, jehož výrazem byl vznik prvních západních univerzit, mj. v Boloni, Pařiži, Oxfordu a Modeně. Intelektuální kvas rodící se v těchto centrech způsobil, že vznikalo čím dál více vysokých škol, a to i na východě Evropy, což přispělo k postupnému rozšíření vyššího vzdělání a k celoevropské výměně idejí a myšlenkových 
proudů. Postupem doby, zároveň s rozvojem humanismu v prvních fázích raného novověku, tento jev nabýval na masovosti. Vznikaly další univerzity a akademie, které poskytovaly větší možnosti rozvoje lidem, zamýšlejícím rozšířit si svůj myšlenkový horizont. Projevovalo se to mimo jiné v tzv. peregrinatio academica a od 17. století v čím dál tím více oblíbené grand tour.

Zmínili jsme zatím problematiku novověkých akademických peregrinací, jejichž cílem bylo získání vzdělání za hranicemi rodné země. Příslušníci tehdejší společnosti živě se zajímající o výchovu a k tomu disponující širokými možnostmi se začali vydávat na někdy i mnohaleté cesty po Evropě, jejichž cílem bylo rozširrení vzdělání. Tento přístup byl charakteristický také pro raně novověkou společnost polsko-litevského soustátí, která v rámci možností využívala příležitosti k výjezdu do zahraničních škol. Často se takové cesty, představující významný prvek výchovy části staropolské společnosti, odehrávaly v zemích od Rzeczypospolité vzdálených, jako je Francie, Itálie nebo dokonce Anglie. Je ale třeba obrátit pozornost také k méně odlehlým evropským teritoriím, opustit i dnes typický okcidentální př́stup, pohlédnout na jihozápadní hranici Rzeczypospolité a „navštívit“ Čechy, přesněji samotnou Prahu.

Polská historiografie zajímající se živě o výjezdy polské mládeže na zahraniční studia v novověku zanechala zásadní vědeckou stopu v podobě mnoha publikací, ${ }^{1}$ jež se často soustřed'ují hlavně na statistické vymezení sledované otázky. Marně bychom ale hledali práci pojednávající o mládeži z Rzeczypospolité v Praze $^{2}$ nebo byt' jen zmínky o ní ve studiích věnovaných obecné problematice zahraniční peregrinace studentů z polsko-litevského

1 Je třeba zmínit především tyto práce: Marian Cнаснал, Podróże edukacyjne młodzieży z Prus Królewskich do Bolonii, Sieny i Perugii w XVI i XVII wieku, in: Jacek Wijaczka (ed.), Prusy Książęce i Prusy Królewskie w XVI-XVIII wieku, Kielce 1997, s. 195-210; TÝž, Protestanci polscy na studiach w katolickich uniwersytetach zagranicznych $w$ latach 1564-1660, in: Henryk Gmiterek (ed.), Z dziejów stosunków wyznaniowych w Rzeczypospolitej XVI-XVII wieku, Res Historica 10 (dále RH), 2000, s. 189-202; TÝŽ, Związki kulturalne Sieny i Polski do końca XVIII wieku, Lublin 1998; Henryk BARYCZ, Archiwum nacji polskiej w Uniwersytecie Padewskim, I, Metryka nacji polskiej w Uniwersytecie Padewskim (1592-1745), Wrocław 1971; Maciej Loret, Polskie pielgrzymstwo naukowe w Rzymie od XVI do XVIII w., Nauka Polska 11, Warszawa 1929, s. 131-173; Bronisław NADOLSKI, Wyjazdy młodzieży gdańskiej na studia zagraniczne w XVII wieku, Rocznik Gdański 24, Gdańsk 1965, s. 173-217; Marian PAWLAK, Studia uniwersyteckie młodzieży z Prus Królewskich w XVI-XVIII w., Toruń 1988; Dorota ŻoŁĄcz-Strzelczyk, Peregrinatio academica. Studia młodzieży polskiej z Korony i Litwy na akademiach i uniwersytetach niemieckich w XVI i pierwszej połowie XVII wieku, Poznań 1996; Stanisław Koт, Stosunki Polaków z Uniwersytetem Lowańskim: w 500 rocznicę otwarcia Uniwersytetu w Lowanjum, Lwów 1927; Paweł Czaplewski, Polacy na studiach w Ingolsztadzie, Poznań 1914; Józef Kallenbach, Polacy w Kolonii. Z metryk uniwersytetu kolońskiego (1388-1628), Archiwum do Dziejów Literatury i Oświaty w Polsce VI, 1890, s. 333-339; Mathias Bersohn, Studenci Polacy na uniwersytecie bolońskim w XVI i XVII wieku, II, Kraków 1894; Zdzisław PIETRZYK, W kręgu Strasburga. Z peregrynacji młodzieży z Rzeczypospolitej polsko-litewskiej w latach 1538-1621, Kraków 1997; TÝž (ed.), Z Piaseczna w świat. Diariusz Zygmunta Opackiego z lat 1606-1651, Kraków 2001; TÝž (ed.), Aleksandra GoliK-Prus (překlad), Peregrynacja Jana Heidensteina przez Belgię, Francję $i$ Włochy $w$ roku 1631 zaczęta a $w$ roku 1634 zakończona, Kraków 2005; Anna Markiewicz, Podróże edukacyjne w czasach Jana III Sobieskiego. Peregrinationes Jablonovianae, Warszawa 2011; Karolina TARGosz, Jana Sobieskiego nauki i peregrynacje, Wrocław - Warszawa 1985; Adam Andrzej WiTusik, Peregrynacje zagraniczne Tomasza Zamoyskiego w latach 1615-1617, Annales Universitatis Mariae Curie-Skłodowska 25, 1972, s. 29-47; Krystyna MuszYŃsKA, Jasia Ługowskiego podróże do szkół w cudzych krajach 1639-1643, Warszawa 1974; Jan KarŁowicz, Polacy na Wszechnicy Heidelberskiej XV-XVIII, Poznań 1887.

2 V poslední době se ovšem soustavnější zájem o toto téma přece jen projevuje, srov. Robert Tomasz TomczAK, Studenci ze Święciechowy na Uniwersytecie praskim w XVII i XVIII wieku, Rocznik Leszczyński 15, 2015, s. $115-124$. 
soustátí. ${ }^{3}$ Dokonce i dílčí pohled na dějiny polské kultury (16.-17. století), který vznikl na základě výzkumu matrik zahraničních univerzit, nebere v potaz matriky pražské univerzity. ${ }^{4}$ Jediný pokus o syntetický přehled polských akademických kontaktů s pražským vysokým učením zpracoval Henryk Barycz. ${ }^{5}$ Jeho studie, přes veškerou vědeckou hodnotu, nemohla problematiku postihnout vyčerpávajícím způsobem, protože dějiny těchto vazeb od středověku až do začátku 20. století byly představeny ve velmi stručné formě (40 stran). Svůj archivní výzkum prováděl H. Barycz během krátkého pobytu v Praze v roce 1936; měl tak možnost využít pramenů, které jsou dnes nedostupné, protože je odvezli nacisté v roce 1945 (a dodnes nebyly nalezeny). Rovněž Henryk Gmiterek při výzkumu polských intelektuálních kontaktů s pražským vysokým učením nepřekročil období renesance. ${ }^{6}$ Ani česká historiografie reflektující tematiku studentů z polsko-litevského soustátí na pražské univerzitě v 17. a 18. století není právě rozsáhlá, i když v jejím př́ípadě je to celkem pochopitelné. ${ }^{7}$

Jeví se tedy jako nezbytné ujmout se badatelského projektu majícího za cíl důkladné prozkoumání otázek týkajících se mládeže z Rzeczypospolité, jež se rozhodla pro studium na pražské univerzitě v 17. a 18. století. Aby se autor vyhnul pouhému statistickému př́ístupu k tématu, rozhodl se pro mnohem širší formu představení pražských studií mládeže z Rzeczypospolité, jež by kromě klasického prosopografického přístupu obsahovala také prvky srovnávacího, genealogického, biografického a samozrrejmě i statistického výzkumu. Za článkem následuje př́loha obsahující biogramy studentů z Rzeczypospolité, kteří studovali na pražské univerzitě.

Zásadní pramenný materiál, neopomenutelný při studiu dané problematiky, představují staré tisky, matriky a alba studentů ${ }^{8}$ vzniklé na pražské univerzitě a většinou uložené

3 Pouze v jediné studii, M. Pawlak, Studia uniwersyteckie, byli statistickým způsobem zpracováni studenti imatrikulovaní v Praze, ale i tak byly sledovány pouze osoby pocházející z Královských Prus a výzkum byl založen pouze na editovaném albu jezuitské akademie z let 1565-1624. Srov. Miroslav Truc (ed.), Album academiae Pragensis Societatis Iesu 1573-1617 (1565-1624), Praha 1968.

4 Marian Снаснал, Metryki zagranicznych uniwersytetów i akademii jako źródło do dziejów kultury polskiej (XVI-XVIII w.), in: Henryk Barycz (ed.), Studia z dziejów epoki Renesansu, Warszawa 1979, s. 37-56.

Henryk Barycz, Dziejowe związki Polski z Uniwersytetem Karola w Pradze, Poznań 1948.

6 Henryk GMitereK, Związki intelektualne polsko-czeskie w okresie Odrodzenia (1526-1620), Lublin 1989.

7 Práce zabývající se studenty pražské univerzity se jen okrajově zmiňují o tam studující mládeži z Rzeczypospolité, přičemž se jedná především o statistické údaje ve vztahu k jednotlivým fakultám. Karel KuČERA - Miroslav TRUC, Zahranični studenti na pražské právnické fakultě v 17. století, Právněhistorické studie 11, 1965, s. 70-72; Milan MošKoř, Skladba a uplatnění inteligence vychovávané pražskou filozofickou fakultou v letech 1654-1730, Acta Universitatis Carolinae - Historia Universitatis Carolinae Pragensis (dále AUC-HUCP) 27/2, 1988, s. 86.

8 Matricula facultatis iuridicae Universitatis Pragensis 1638-1686, Archiv Univerzity Karlovy (dále AUK), fond Matriky (dále f. Matriky), sign. M 6; Matricula facultatis medicae Universitatis Pragensis 1657-1783, tamtéž, sign. M 63; Matricula renovata continens nomina dominorum jurisstudiorum ab anno 1638 usque 1762 secundum ordinem alphabeticum, tamtéž, sign. M 12; Marticula Universitatis Pragensis, rectorum, decanorum, professorum et speciatim in facultate philosophica graduatorum 1654-1736, tamtéž, sign. M 22; Protocollum facultatis Iuridicae Universitatis Pragensis ab anno 1681, tamtéž, sign. M 7. Srov. Antonín Alexandr Franchimont z Frankenfeldu, Patheno-Sophia sive Virginalis sapientia Catharinae... Anno vero a partu Virginis M.DC.LVIII a Michaele Serenissimo \& Potentissimo Polon: Rege aemula pietate philosophis Pragensibus in sua sffige in venerationem proposita ediemque Maiestati Affectu reverendissimo iterum consecrata, Praha 1670, AUK, fond Sbírka starých tisků (dále AUK, f. SST), č. 310; Konvolut oznámeni o promocích, I (1624-1690, 1650-1690), bez č. (1673-1690), II (1690-1697), III (1697-1701), IV (17011705), V (1705-1710), VI (1710-1716), VII (1716-1720), VIII (1720-1725), IX (1725-1729), X (1729-1733), XI (1733-1739), XII (1739-1805), AUK, fond Úřední tisky Karlo-Ferdinandovy Univerzity (dále AUK, f. ÚT KFU); Martin Xavier Volkman, Gloria Universitatis Carolo-Ferdinandeae Pragensis trignita tribus encomiis orbi divulgata...Typis Universitatis Carolo-Ferdinandeae, Praha 1672. 
v Archivu Univerzity Karlovy, stejně jako alba a matriky částečně vydané, ${ }^{9}$ a dále pak prameny k dějinám této univerzity uložené v jiných pražských vědeckých institucích. ${ }^{10}$ Prameny, které máme v současné době k dispozici, bohužel neumožňují úplné zpracování tématu, nebot' se dochovala jen nevelká část matrik a alb. Z tohoto důvodu zůstal časový rámec omezen na 17. a 18. století: prameny pro filozofickou fakultu zachycují léta 1624-1805, pro lékařskou fakultu 1657-1783 a pro právnickou fakultu 1638-1762. Matriky teologické fakulty se nedochovaly vůbec. ${ }^{11}$

Aby bylo možné odpovědět na některé otázky, bylo nutné vedle výše uvedených pramenů sáhnout také po matrikách a albech jiných vzdělávacích institucí doma i za hranicemi, ${ }^{12}$ projít soudobé relace o Čechách a Praze ${ }^{13}$ a rovněž shromáždit polské prameny nezbytné k poznání studia Michala Korybuta Wiśniowieckého, ${ }^{14}$ u nějž bylo pražské období jeho edukace historiky dosud zcela opomíjeno nebo opakovaně marginalizováno. Je třeba také dodat, že v polských archivech jsou uloženy prameny vypovídající o trojici Poláků, kteří absolvovali studia v Praze. Jedná se o Kazimíra Wielopolského, pro nějž disponujeme potvrzením svědčícím o absolvování studia (3. září 1683), vystaveným děkanem Vilémem Dvorským, ${ }^{15}$ a o bratry Jiřího Josefa a Karla Stanislava Radziwiłły, kteří po sobě zanechali poznámky z pražských filozofických přednášek v roce 1684 . ${ }^{16}$ Pro potřeby tohoto

9 Karel BerÁneK (ed.), Acta facultatis philosophicae Universitatis Pragensis 1641-1655, 1664-1670, Praha 1994; Miroslav Truc (ed.), Album Academiae Pragensis Societatis Iesu 1573-1624, Praha 1968; Karel BERÁNEK (ed.), Magistri, baccalaurei nec non studentes facultatis philosophicae Pragensis 1640-1654, Praha 1998; Karel KuČERA - Miroslav TRUC (edd.), Matricula facultatis medicae Universitatis Pragensis 1657-1783, Praha 1968.

10 Artium Liberalium et Philosophiae Baccalaurei in Universitate Carolo-Ferdinandea Pragensi ab anno MDCCXXIV inclusive Promoti, Knihovna Národního Muzea v Praze, VI A 4. Dále srov. akademické teze uložené v Národní knihovně České Republiky (dále NK ČR), sign. Th. 027; Th. 346; Th. 495; Th. 496.

11 Karel KuČERA - Miroslav Truc, Archiv University Karlovy - Průvodce po archivních fondech, Praha 1961, s. 171-172.

12 Willem Nikilaas Du RiEu (ed.), Album studiosorum Academiae Lugduno Batavae MDLXXV-MDCCCLXXV: accedunt nomina curatorum et professorum per eadem secula, Leyden 1875; Jerzy ZATHEY (ed.), Album studiosorum Universitatis Cracoviensis, tomus IV, Continens nomina studiosorum ab anno 1607 ad annum 1642, Kraków 1950; Karol Lewicki (ed.), Album studiosorum Universitatis Cracoviensis, tomus V, Continens nomina studiosorum ab anno 1720 ad annum 1780, Kraków 1956; Henryk GMiterek (ed.), Album studentów Akademii Zamojskiej 1595-1781, Warszawa 1994; Zbigniew NowaK - Przemysław SzAFrAn (ed.), Catalogus Discipulorum Gymnasii Gedanensis 1580-1814, Warszawa - Poznań 1974; Hugo ABs (Hg.), Die Matrikel des Gymnasiums zu Elbing (1598-1786), Gdańsk 1936; Georg ErLer (Hg.), Die Matrikel und die Promotionsverzeichnisse der Albertus-Universität zu Königsberg i. Pr. 1544-1829, I, Die Immatrikulationen von 1544-1656, II, Die Immatrikulationen von 1657-1696, Leipzig 1910, 1911-1912.

13 Dyaryusz peregrinatyi niemieckey, czeskiey y włoskey ziemi czyniony przez mnie Theodora Billewicza, stolnika żmudzkiego, Anno 1677, Mense Augusto 13 dnia, Biblioteka Kórnicka Polskiej Akademi Nauk (dále BK PAN), rkps. BK 386, Mf. 358, srov. také edici téhož pramene: Teodor Billewicz, Diariusz podróży po Europie w latach 1677-1678, ed. Marek Kunicki-GoldFinger, Warszawa 2004; Aleksander HirschBerg (ed.), Dyaryusz legacyi Jerzego Ossolińskiego posła polskiego na sejm Rzeszy niemieckiej w Ratyzbonie w roku 1636, Lwów 1877.

14 Kněz Jan Chryzostom Fabricius Janu Zamojskému se zprávou o zdraví a pokrocích knížete Michała Wiśniowieckého, 6. května 1653, Archiwum Główne Akt Dawnych w Warszawie (dále AGAD), Archiwum Zamoyskich (dále AZ) 1062; dopis Felicjana Wąsowicze Janu Zamojskému se zprávou o studiu Michała Wiśniowieckého v Praze, 25. listopadu 1656, AGAD AZ 1155; dopis královny Ludwiky Marie Janu Zamojskému, 10. února 1660, AGAD AZ 1107; testament krále Michała Korybuta Wiśniowieckého, 5. listopad 1673, AGAD, Archiwum Warszawskie Radziwiłłów (dále AWR) 1610; Opisanie dworu, rzeczpospolitej i królestwa polskiego przez Galeazzo Marescotti, arcybiskupa Koryntu, nuncyusza Stolicy Apostolskiej w latach 1670 i 1671, in: Erazm RYKACZEWSKi (ed.), Relacye nuncyuszów apostolskich i innych osób o Polsce od roku 1548 do 1690, II, Poznań - Berlin 1864, s. 361-389.

15 Biblioteka Narodowa w Warszawie (dále BNW), rkp. 3093, f. 8.

16 Opusculum in universam philosophiam, BNW, rkps. 6746 II. 
zpracování ale bratři Radziwiłłové mezi analyzovanou skupinu studentů zahrnuti nebyli, protože pobývali v Praze dosti krátce a přednášky z filozofie poslouchali u jistého františkána - mohli se tedy účastnit jen soukromých přednášek. ${ }^{17} \mathrm{U}$ Wielopolského zase není zcela jisté, jak dlouho a jakým způsobem v Praze studoval, protože se v univerzitních matrikách, albech a tiscích nevyskytuje a jeho pražský pobyt byl pouze zastávkou během pětileté cesty po Evropě. 18

\section{Univerzity a edukace v době I. Rzeczypospolité}

Na počátku je třeba se zamyslet nad motivací polských studentů, která je vedla k rozhodnutí o studiích právě na pražské univerzitě. Jedná se však o otázku z kategorie obtížných či nezodpověditelných, zvláště uvážíme-li, že není v naší moci „ocitnout se v kůži““ člověka ze 17. a 18. století a jednoznačně popsat důvody jeho rozhodnutí. Bylo by to možné, kdybychom disponovali alespoň psanými vzpomínkami těchto studentů, ale protože je nemáme, musíme se pohybovat v oblasti polopravd a dohadů. Jediná otázka, na niž bychom mohli přesněji odpovědět, se týká toho, proč polští studenti, kteří se nakonec rozhodli k cestě do Prahy, nestudovali raději na některé z vysokých škol v Rzeczypospolité. Odpovědět je možné s pomocí krátkého představení dějin tří polských vysokých škol (Jagellonská univerzita, Akademie v Zamości, vilenská akademie) a jedné pruské (univerzita v Královci), a to hlavně v 17. století, které je zvláště důležité, vezmeme-li v potaz největší počet polských studentů pobývajících v Praze právě v tomto století. Získáme tak určitý celkový obraz vyššího školství v Polsku ve sledované době a pokusíme-li se zároveň zkompletovat údaje o intelektuálních migracích Poláků v 17. a 18. století, stane se výsledný obraz svého druhu odpovědí na otázku týkající se motivace studentů Rzeczypospolité, kteří se rozhodli právě pro pražskou univerzitu. V úvahu je také třeba vzít skutečnost, že v průběhu dvou staletí prošlo posluchárnami pražského vysokého učení na sto dvacet polských studentů, zatímco na jiných vysokých školách, např. německých nebo nizozemských, bývalo takového počtu dosaženo během necelého jednoho desetiletí. Zdá se, že společnost I. Rzeczypospolité byla hluchá k radám jednoho z hlavních barokních moralistů Polska konce 17. století, Wacława Potockého, který ve svém cyklu Braterskie admonicje (Bratrská napomenutí) napomíná šlechtické kolegy:

Szuka prostak strumyka mając źródło blisko.

Toż z siebie szlachta polska czyni śmiechowisko,

Kiedy włóczac po cudzych ziemiach z kosztem szuka,

Jakby nie taż w Krakowie, co w Pradze nauka.

Radzi by z nich ojcowie wykurzyli Czechy,

Skoro podwiki, skoro w nich nawykna wiechy,

Chyba, że od chodzenia i darcia trzewików

Z greckiego, jako czytam, zwą akademików.

17 Karol Stanisław Radziwııє, Diariusz peregrynacji europejskiej (1684-1687), ed. Adam Kucharski, Toruń 2011, s. 33.

18 Adam Kucharski, Theatrum peregrinandi. Poznawcze aspekty staropolskich podróży w epoce późnego baroku, Toruń 2013, s. 277. 
I w Krakowie nikomu nie kłada trynogu-

Nabiega się leda gdzie mikusia na rogu. ${ }^{19}$

(Prost'áček hledá pramínek, ač má blízko pramen.

Tak se polská šlechta vystavuje posměchu,

když se za velkých nákladů trmácí po cizích zemích,

jako by v Krakově nebyla ta samá nauka co v Praze.

Otcové by jim rádi dostali z hlav Čechy,

aby si tam nenašli nevěsty nebo nenavykli na hospody.

Snad od chůze a trhání střevíců

z řečtiny, jak čtu, jsou nazýváni akademiky.

A v Krakově nikomu nekladou přkéǎky -

ledaskde lze na rohu natrefit na poběhlici.)

Wacław Potocki dává ve svých verších polské šlechtě jasně najevo, že není nic špatného na studiu jak v domácích intelektuálních centrech, jakým je např́íklad Krakov, tak v relativně nedaleké Praze. Tvrdí, že přes obavy šlechticů nebudou jejich synové ,běhat za děvčaty“ (podwiki), ani nebudou marnit čas v hospodách. Svým „bratřím“ se trochu vysmívá, když namítá, že cestování po cizích krajích neudělá z nikoho učence. Uzavírá proto poučkou, že to, co potřebujeme, se často nachází blíže, než si myslíme. Je ale třeba upozornit i na to, že Potockého úvahy nebyly zcela pravdivé, protože samotná existence univerzit v polských zemích nebyla vždy zárukou požadované vysoké úrovně výuky.

Nejvýznamnější a nejstarší ze skupiny polských vysokých škol je samozřejmě Jagellonská univerzita, která byla v 17. věku zásadním způsobem paralyzována a omezena v rozvoji. Hlavním důvodem se stal dlouhodobý konflikt s jezuitským řádem, který probíhal na pozadí sporu o monopol na výuku v rámci zemí polské koruny (vrcholící v letech 1622-1634, 1650, 1661-1662, 1678). Toto soupeření sice skončilo patem, ale krakovské vysoké učení jej zaplatilo úplným vyčerpáním svého intelektuálního potenciálu. Vedle toho docházelo také $\mathrm{k}$ rozmíškám mezi profesory a k vnitřním neshodám na katedrách. $\mathrm{Z}$ tohoto důvodu byly některé katedry na filozofické, lékařské a právnické fakultě řadu let neobsazené. Významní učenci opouštěli univerzitu a docházelo také ke konfliktům s krakovskými biskupy v důsledku sporů o samostatnost školy (1647-1655 s Piotrem Gembickým, 1658-1679 s Andrzejem Trzebickým). Organizačně i svou strukturou představovala navíc univerzita stř̌edověký útvar. Tím, že se nemohla přizpůsobit novodobým potřebám a trendům v oblasti duchovní kultury, začínala kostnatět a ztrácela na někdejším významu. Ačkoli oproti západoevropským univerzitám zaostávala, přece jen byla i nadále největším akademickým centrem a ohniskem intelektuálního potenciálu Polska doby baroka. V její neprospěch působila také okupace Krakova švédskými a sedmihradskými vojsky v době „Švédské potopy“ a drastické důsledky epidemií - v důsledku jedné z nich byly takřka po

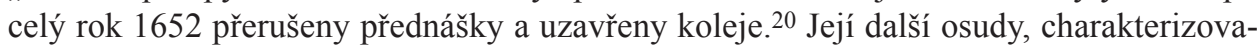
né naprostým konzervatismem, pak směřovaly po šikmé ploše stále více k okrajovému

19 Wacław Pотоскі, Opuściwszy źródło szuka potoku, in: Jan Dürr-Durski (ed.), Pisma wybrane, II, Warszawa 1953, s. 122.

20 Adam Przyboś, Akademia Krakowska w drugiej połowie wieku XVII, in: Karol Lepszy (ed.), Dzieje Uniwersytetu Jagiellońskiego w latach 1364-1764, I, Kraków 1964, s. 312-313. 
postavení na intelektuální mapě země. V 18. století byla Jagellonská univerzita předstižena jezuitskými a piaristickými středními školami. Dobou stagnace byla i saská éra; univerzitu z ní vysvobodila teprve reforma a nová koncepce vysokého školství, provedená Hugo Kołłątajem za panování krále Stanislava Augusta Poniatowského. ${ }^{21}$ Právě z Kołłątajova pera pochází poněkud přemrštěné, ale sugestivní tvrzení: ,przyznać z żalem potrzeba, że ta sławna niegdyś catej Polski szkoła, w bardzo lichym znajdowata się stanie“22 (je třeba si se smutkem přiznat, že ona někdejší slavná škola celého Polska se nacházela ve velmi špatném stavu).

Druhou vysokou školou v polských zemích byla tehdy Akademie v Zamości, jež vznikla na konci 16. století (1594) díky úsilí velkého korunního kancléře Jana Zamojského. Tato nová instituce byla zpočátku nevraživě sledována krakovskou univerzitou i jezuity a první léta její existence nebyla jednoduchá. Hippaeum Zamoscianum mělo být svou povahou světskou školou, jejíž absolventi měli být skvěle připraveni k zaujetí odpovídajících funkcí ve státní správě. Zakladatel svou školu velkoryse vybavil (zděné budovy pro byty profesorů, ubytování studentů i výuku) a přivedl znamenité vyučující, do značné míry ze zahraničí. ${ }^{23}$ Jeho cílem bylo přibližit se standardům západoevropské výuky a získat škole mezinárodní věhlas, což mělo být zajištěno mimo jiné převzetím vzorů akademie ve Štrasburku. Smrt Jana Zamojského v roce 1605 značně zbrzdila počáteční slibný rozvoj. Snaha soustředit rozhodování o akademii v rukou chelmského biskupa Jiř́iho Zamojského potlačovala její světský charakter a vedla $\mathrm{k}$ posílení středověce-scholastického směru a $\mathrm{k}$ převaze teologie. ${ }^{24} \mathrm{Z}$ tohoto důvodu vypukl konflikt mezi biskupem a fundací Zamojských, který trval po celé 18 . století a způsobil zmatky, ba svého druhu anarchii. ${ }^{25}$ Nepř́znivě působil také nedostatek profesorů. I když bylo finanční zajištění vyučujících lepší než v Krakově, řada $\mathrm{z}$ nich považovala své působení na akademii pouze za předstupeň $\mathrm{k}$ získání profesury právě $\mathrm{v}$ Krakově nebo lukrativního místa na dvoře krále či některého $\mathrm{z}$ magnátů, případně v městských službách (radní, písaři). S tím vším souvisí značné zmenšení počtu šlechtických studentů coby základního činitele pro úspěch světské vysoké školy. Město navíc postihly také četné živelní pohromy (mj. požár v roce 1628). Akademie se čím dál tím více připodobňovala ke krakovské univerzitě, vznikl dokonce plán, aby se stala filiálkou této vysoké školy. Vezmeme-li v potaz navíc i švédský vpád, není výsledný obraz př́liš uspokojivý. Škola v Zamości byla př́liš mladá na to, aby stihla zapustit kořeny na intelektuální mapě Polska a Evropy. Žila z ducha a majetku zakladatele, ale jakmile byl obojího nedostatek, ztratila životní sílu a perspektivy rozvoje. ${ }^{26}$

Pro Velkoknížectví litevské byla k dispozici rovněž nově založená vilenská akademie, přetvořená králem Štěpánem Bátorym v roce 1579 z jezuitské koleje. Bylo to jediné vysoké učení ve Velkoknížectví a skládalo se ze dvou fakult, filozofické a teologické. Počátky existence akademie byly slibné; takřka celý profesorský sbor tvořili cizinci a ochrannou ruku

21 Emannuel Rostworowski, Czasy saskie (1702-1764), in: K. Lepszy (ed.), Dzieje Uniwersytetu Jagiellońskiego, S. 365-366.

22 Hugo KoŁŁątaj, Stan Oświecenia w Polsce w ostatnich latach panowania Augusta III (1750-1764), Warszawa 1905, s. 75.

23 Stanisław ŁemPICKI, Działalność Jana Zamoyskiego na polu szkolnictwa 1573-1605, Kraków 1921, s. 102.

24 Tamtéž, s. 11.

25 Jan Karol Kochanowski, Dzieje Akademii Zamojskiej (1594-1784), Kraków 1900, s. 164-165.

26 Henryk BArycz, Barok, in: Bogdan Suchodolski (ed.), Historia nauki polskiej, II, Wrocław - Warszawa Kraków 1970, s. 62-65. 
nad ní držel král Zikmud III. Vasa. Rozvíjela se vědecky, rozrůstaly se studentské koleje i knihovna, jejíž fond značně rozšílily dary Kazimíra Lva Sapiehy a Eustacha Wołłowicze. Škola byla typickou jezuitskou univerzitou, jejímž cílem byl boj s jinověrstvím, tedy upevňování a rozšiřování katolicismu na Litvě a $\mathrm{v}$ sousedních zemích, kde převládalo luterství. Veškerý vědecký potenciál byl opanován úkoly spojenými s náboženstvím a teologické vědy tak na škole zcela převážily. Přesto byla její spádová oblast nevelká a vliv poměrně malý. Počet studentů v roce 1628 nepřekročil osm set, nebyla to tedy na svou dobu velká vzdělávací instituce. Její rozkvět nastal v letech 1640-1655, kdy získala díky privilegiu krále Vladislava IV. možnost utvořit obě zbývající fakulty, právnickou a lékařskou, ale skutečně se to podařilo pouze v př́padě první z nich. ${ }^{27}$ Záhy prrišlo kataklyzma. Dne 8 . srpna 1655 do Vilna vstoupila moskevská vojska, což způsobilo naprostý rozvrat a útěk vyučujících (hlavně do Královce). ${ }^{28}$ Později bylo podniknuto několik pokusů vyvést akademii z krize: $\mathrm{v}$ roce 1674 vznikla katedra politiky a v roce 1675 došlo $\mathrm{k}$ pokusu zorganizovat studia matematiky. Snahy o povznesení školy na lepší úroveň se však nezdařily, a tak zůstala uzavřena v teologické rutině a náboženském fanatismu. ${ }^{29}$ Teprve po více než sto letech (1796/1797) došlo k oživení vilenské akademie, ovšem pod změněným názvem Vilenská hlavní škola a pod cizím, ruským protektorátem. ${ }^{30}$

Čtvrtou a poslední vysokou školou, o níž je třeba se zmínit, byla univerzita v Královci, založená Albrechtem Hohenzollernem v roce 1544 - odtud i její označení Albertina. Tato vysoká škola sice nepatř́i mezi polské školy v plném slova smyslu, ale vzhledem $\mathrm{k}$ její geografické poloze a silnému vlivu polských akademických center je třeba vzít ji pro účely této studie v potaz. Kromě toho byl Královec do roku 1657 lénem Rzeczypospolité a díky privilegiu polského krále Zikmunda Augusta z roku 1560 získala nová univerzita ty samé výsady jako krakovská akademie. ${ }^{31}$ Albertina byla v 17. a 18. století sice provinční, ale stále se rozvíjející vysokou školou. $V$ době třicetileté války přicházeli právě do Královce, vzdáleného hlavním bojištím, studenti a učenci z německých zemí, což mělo nemalý vliv na rozvoj Albertiny. Její prestiž vzrostla po prvních doktorských promocích v roce $1640^{32}$ a její materiální rozvoj zajistila péče „velkého kurfiřta“ Fridricha II. Ten založil mimo jiné četná zahraniční stipendia pro úspěšné studenty a rozvinul kontakty s holandskými univerzitami. Kromě toho „europeizoval“ lékařskou fakultu založením lékárnického studia, čímž také poskytl základnu pro rozvoj tohoto zdravotnického odvětví v samotném městě. ${ }^{33}$ Do 18. století vstupovala Albertina jako královská univerzita, poté co byl Fridrich III. korunován na pruského krále. Její prestiž tím vzrostla, ale, jak se později ukázalo, jen nakrátko. Vláda Fridricha Viléma I., jehož akademické záležitosti nezajímaly, se pro univerzitu stala těžkým obdobím, zvláště když byli její studenti hojně verbováni do vojska. Úpadek zastavila až vláda Fridricha II. a všeobecné rozšíření idejí osvícenství. Stav školy nebyl nejhorší a po magisterské promoci řemenářského syna Immanuela Kanta se univerzita v Královci stala podstatně známější v evropských akademických kruzích. Další osudy Albertiny

27 Józef BALIŃsKi, Uniwersytet Wileński (1579-1831), III, Kraków 1899-1900, s. 506-510.

28 Ludwik JANOwski, Wszechnica Wileńska 1578-1842, Wilno 1921, s. 1-6.

29 Michał Balı́śski, Dawna Akademia Wileńska. Próba jej historyi od założenia w roku 1579 do ostatecznego jej przeksztatcenia w roku 1803, Petersburg 1862, s. 154-183.

30 L. JANOWSKI, Wszechnica Wileńska, s. 7.

31 Janusz JAsIŃski, Historia Królewca, Olsztyn 1994, s. 49.

32 Jerzy Serczyк, Albertyna. Uniwersytet w Królewcu (1544-1945), Olsztyn 1994, s. 43.

33 Tamtéž, s. 48. 
nejsou pro naše téma podstatné, je ale třeba dodat ještě jednu zásadní věc - univerzita byla od samého počátku protestantská, se silně ortodoxním luteránským zabarvením. ${ }^{34}$ Ačkoli byla katolíkům přístupná, byla polskou společností vnímána jako cizí, či přímo nepřátelská instituce.

Nyní je na místě shrnout výše uvedené údaje a doplnit je o další jevy spojené s akademickou peregrinací mládeže Rzeczypospolité na pozadí situace celé země. Pokud k načrtnutému obrazu polského a pruského vysokého školství v 17. a 18. století připočteme vnitropolitickou a zahraničněpolitickou situaci Polska, konkrétně války se Švédy, Tatary, Tureckem, kozáky a Ruskem, i obtížnou hospodářskou situaci, máme před sebou obraz země, který nebyl př́íznivý vědě, novým intelektuálním proudům ani akademické atmosféře obecně. Ovšem stagnace univerzit byla té době v Evropě jev obecnější povahy, zvláště vezmeme-li v úvahu zpátečnické a tvrdošíjné stanovisko církve v oblasti vědy a výuky, které vedlo k úpadku zejména katolických univerzit, včetně těch polských. Albertina byla výjimkou, ale zájem o ni ze strany studentů katolického vyznání v souvislosti s protireformací slábl, což dodatečně umocňoval také fakt, že nebyla uznána papežem ani císařem. Ostatní části Evropy samožrejmě také nebyly uchráněny válek, epidemií a krizí jiného druhu, ale je vcelku zřejmé, že podmínky pro studium byly na Západě o dost lepší než v Rzeczypospolité. Nemělo by nás proto překvapit, že Poláci, kteří se rozhodli nestudovat v Polsku, si vybírali pouze ty ze zahraničních škol, jež jim nabízely nejen klid a zvýšení prestiže, ale také lepší podmínky rozvoje. Týká se to i studentů z Rzeczypospolité v Praze (pouze dva polské studenty z Prahy lze nalézt také $\mathrm{v}$ albech a matrikách polských vysokých škol, konkrétně to jsou: Andrzej Jahling, zapsaný na Albertině v roce 1650,35 a Jan Auxenty Owaniszowic, student Akademie v Zamości z let 1676/1677). ${ }^{36}$ Motivace studentů, kteří se rozhodli pro Prahu, mohla mít prostý důvod: odmítnutí polských univerzit s ohledem na jejich stagnaci, ortodoxii, vnitřní problémy a časem také chronický úpadek. Tato odpověd' je ale relevantní pouze ve vztahu k polským vysokým školám. Zbývá ještě zamyslet se, proč se rozhodli právě pro Prahu a ne pro některou ze západoevropských univerzit.

Z hlediska topografie se kulturně-intelektuální peregrinace Poláků v 17. a 18. století koncentrovala hlavně na Itálii (Padova, Řím, Florencie), Německo (Lipsko, Frankfurt nad Odrou, Štrasburk, Altdorf, Heidelberg), Rakousko (Ingolstadt, Vídeň, Štýrský Hradec), Holandsko (jen v roce 1636 se na čtyřicet polských studentů zapsalo na univerzitě v Leydenu) a samozřejmě Francii (Paříž, Orleans, Saumur, Sedan, Angers). Vzdělání a dvorský lesk hledaly v zahraničí největší polské šlechtické rody (Sobieští, Leszczynnští, Slupští, Sapiehové, Radziwiłłové). Není divu, že v těchto př́ípadech bychom těžko shledali jako cíl edukačních cest Prahu. Henryk Barycz uvádí, že na belgické univerzitě v Lovani se v první polovině 17. století zapsalo sto Poláků, prričemž tvrdí, že se nejednalo o jev masový. Vedle toho zmiňuje jako atraktivní cíl pro polské studenty také vzdálenou Anglii. ${ }^{37} \mathrm{Na}$ pražské univerzitě nemáme $v$ průběhu dvou století co do činění $s$ více než dvěma sty studentů z Rzeczypospolité. Praha se nám proto jeví z hlediska Poláků jako duchovní centrum zcela marginální a neatraktivní. Proč si ale více než sto z nich zvolilo právě tuto vysokou

34 Henryk Barycz, Podzwonne Uniwersytetowi Królewieckiemu, in: H. Barycz (ed.), Z dziejów polskich wędrówek naukowych za granicę, Wrocław - Warszawa - Kraków 1969, s. 452.

35 G. Erler (Hg.), Die Matrikel, s. 513.

36 H. Gmiterek (ed.), Album studentów, s. 271.

37 H. BARYCZ, Barok, s. 21-32. 
školu? Bylo to $\mathrm{z}$ důvodů topografických (pro studenty z Velkopolska byla mnohem blíže než Krakov), nebo ekonomických (náklady na studium v Praze byly mnohem nižší než v Paříži nebo Vídni), př́ípadně i z jiných, blíže neznámých důvodů? To bohužel nemůžeme na základě pramenů zcela jednoznačně usoudit, ač $\mathrm{v}$ př́padě motivace studentů $\mathrm{z}$ města Święciechova je možné určité závěry vyvodit (srov. dále). Musíme se tedy spokojit s konstatováním, že v Polsku se přece jen našla řada osob, jež vzaly Prahou a její univerzitou zavděk a získaly tu své první akademické hodnosti.

\section{Edukační cíle šlechty a měšt’anstva Rzeczypospolité v 17.-18. století}

Poté, co jsme poznali faktory, které mohly způsobit odjezd polských studentů do Prahy, respektive za hranice obecně, je třeba zamyslet se nad tím nejdůležitějším aspektem: proč především se v 17. a 18. století mladí lidé rozhodovali pro vyšší vzdělání, pro něž byli ochotni obětovat vysoké náklady, i podniknout namáhavou cestu a studia v cizině, a jaký cíl tím sledovali? Odpovědi budou samozřejmě různé v závislosti na tom, v kontextu jakého prostředí na ně budeme hledat odpovědi: zda šlechtického, či měšt’anského.

Šlechta Rzeczypospolité tvořila ve sledovaném období velmi nesourodé společenství co do majetku, národnosti i vyznání. Bylo samozřejmé, že syn velkého magnáta nebude studovat pouze na domácích školách, pokud se tam vůbec objeví, ale hlavně na renomovaných evropských univerzitách a kolegiích. Mladík z malého šlechtického statku naopak mohl ukončit své vzdělání na domácích gymnáziích a kolegiích a nemusel vůbec príijít do kontaktu s jakoukoli vyšší školou. Určení všeobecně platného modelu edukace šlechty je tedy zcela nemožné, lze však poukázat na určité společné rysy, typické pro celou sociálně-politickou vrstvu. Zásadní je v tomto ohledu také samotná šlechtická kultura, jež udávala tón veškerému jednání př́slušníků šlechtického stavu. Tato kultura se po celou dobu od 16 . do 18. století proměňovala. Počáteční celoevropská propojenost období humanismu ustoupila do pozadí pod vlivem konzervativního a provinčního sarmatismu uzavírajícího šlechtu v hranicích jednotlivých farností, aby se v 18. století díky osvícenství její úzké obzory znovu rozššríly a otevřely novým intelektuálním vzorům a proudům.

Nezanedbatelný vliv na to měly právě edukační modely. Nejtypičtějším obrazem byl tehdy šlechtic vystupující jako mluvčí na sejmících, jenž býval vychován a vzdělán na jezuitských školách protireformační a barokní doby. To ale časem přestávalo platit a bylo nutné nahradit model kladoucí důraz na kvantitu modelem zaměřeným na kvalitu, jehož konkrétní podoba se odrazila $\mathrm{v}$ častých akademických peregrinacích, jejichž cílem bylo nejenom vzdělání, ${ }^{38}$ ale také dvorská etiketa a společenské vystupování. V 17. století dochází k přerodu v oslavovanou grand tour, čili edukaci prostřednictvím cesty po mnoha evropských zemích a dvorech. Střední a nižší šlechta samozřejmě nadále tíhla k sarmatismu a jezuitské výchově, ${ }^{39}$ zatímco aristokracie si zakládala na zahraničních kontaktech. Výchova šlechtického syna obecně, bez ohledu na finanční možnosti, začínala v rodném domě, pokračovala

38 Dorota ŻołĄDź, Ideały edukacyjne doby staropolskiej. Stanowe modele i potrzeby edukacyjne szesnastego i siedemnastego wieku, Warszawa - Poznań 1990, s. 181; Martin Holý, Zrozeni renesančního kavalíra. Výchova a vzdélávání šlechty z českých zemí na prahu novověku (1500-1620), Praha 2010.

39 Bronisław Natoński, Szkolnictwo jezuickie $w$ Polsce $w$ dobie kontrreformacji, in: Janusz Pelc (ed.), Wiek XVII - Kontrreformacja - Barok. Prace z historii kultury, Warszawa - Wrocław - Kraków 1970, s. 308-312. 
v jezuitském nebo jiném gymnáziu, a poté v závislosti na řadě okolností (finanční situace, vyznání, rodinné tradice) byla doplněna zahraniční cestou, aby se po návratu domů dotyčný zapojil do politicko-společenských a hospodářských aktivit. ${ }^{40}$ Cesta byla většinou finančně náročná a dlouhodobá, proto se př́slušníci nižší šlechty obvykle nechávali najímat jako společníci mladých magnátů na post preceptora nebo př́slušníka dvora, aby se při té př́iležitosti mohli rovněž vzdělávat. Vychovatelé sami dosahovali akademických gradů a ze studií často získávali intelektuálně více, než jejich svěřenci. ${ }^{41}$ Aby měli otcové větší vliv na průběh cesty a prostředky výchovy svých synů, vybavovali je podrobnými instrukcemi. Činili tak především magnáti a zámožná šlechta středního postavení, např́iklad Zbyhněv Ossoliński pořídil instrukci pro svého syna Jiř́ho, Stanislav Lubomirski pro syny Teodora a Františka nebo Jakub Sobieski pro bratra Jana a syny Marka a Jana, pozdějšího krále. ${ }^{42}$ Tímto způsobem se snažili kontrolovat předpoklady kariéry svých potomků a dědiců a odpovídajícím způsobem je na ně připravit.

Ačkoliv pouze aristokracie disponovala veškerými prostředky, nezbytnými pro plnou realizaci výše uvedeného modelu a byla svým způsobem predestinována k zaujímání nejvyšších úřadů, také ostatní šlechtici byli povinováni - stejně jako aristokracie - plnit určité závazky $\mathrm{k}$ zemi a $\mathrm{k}$ osudem zkoušeným př́slušníkům svého stavu, což determinovalo podobu jejich edukace. Závazkem šlechtice byla láska $\mathrm{k}$ Bohu a služba vlasti, měl tedy být vzdělán v prvé řadě morálně a nábožensky, a teprve poté i intelektuálně, což se projevovalo určitým pohrdáním vi̊či intelektuální práci, považované někdy za újmu na cti. ${ }^{43}$ Naopak se cenila užitečnost vzdělání potřebného pro práci na poli sejmíků, ač je těžké bezezbytku definovat, jaké vzdělání konkrétně mělo být pro šlechtice $\mathrm{v}$ životě potřebné. Základem zcela jistě bylo vzdělání ve víre, dále morální s důrazem na patriotický charakter a výchova ve vojensko-rytiŕském duchu. ${ }^{44}$ Zapadalo to do sebe s dalším prvkem - intelektuální výchovou, jež pomáhala při realizaci základního vzdělávacího modelu (schopnost čtení, psaní, znalost latiny, latinské literatury a rétoriky). To vše dohromady tvořilo ideální obraz šlechtice, s nímž se ovšem zdaleka ne všichni př́slušníci urozeného stavu ztotožňovali byla otázka, zda být ideálním dvořanem (L. Górnicki), senátorem (W. Goślicki), dobrým občanem (A. M. Fredro) nebo poctivým zemanem (M. Rej). ${ }^{45}$ To vše záviselo na vlastních preferencích, ambicích a předem naplánovaném průběhu kariéry. Jinak vypadal průběh edukace syna předurčeného $k$ duchovnímu stavu (s upřesněním, zda se má stát kanovníkem, scholastikem, nebo biskupem), jinak v př́padě, čekala-li ho kariéra vojáka nebo politika, působícího v lokálních, respektive zemských úřadech. Ke stejnému cíli ale nemusely vést ty samé cesty. Vše záleželo na ambicích, názorech a konexích daného šlechtice, byt' spojujícím článkem tu nepochybně byl patriotický př́stup se silným nábožensko-morálním zabarvením.

40 D. ŻoŁĄDź, Idealy edukacyjne, s. 184.

41 Antoni MĄсZAK, Peregrynacje, wojaże, turystyka, Warszawa 1984, s. 125.

42 tÝž, Życie codzienne w podróżach po Europie w XVI i XVII wieku, Warszawa 1978, s. 170-174; Jerzy Ossoliński, Pamiętnik, ed. Władysław CzAPLiŃski, Warszawa 1976, s. 37-39.

43 Łukasz Kurdybycha, Staropolski ideat wychowawczy, in: Ł. Kurdybacha (ed.), Pisma wybrane, I, Warszawa 1976, s. 41-42.

44 Stanisław Łempicki, Polskie tradycje wychowawcze, Warszawa 1936, s. 11-17.

45 Ł. Kurdybycha, Staropolski ideał wychowawczy, s. 82-86; Henryk Barycz, Andrzej Maksymilian Fredro wobec zagadnień wychowawczych, Kraków 1948, s. 1-13; Mikołaj Res z NAGŁowic, Zwierciadlo, wyjątki, in: Józef Skoczek (ed.), Wybór pism pedagogicznych Polski doby Odrodzenia, Wrocław 1956, s. 320-361. 
Edukační cíle měšt’anstva Rzeczypospolité byly samozřejmě zcela jiné než ty šlechtické. Základní podobností je v podstatě silné rozvrstvení tohoto stavu (plebs, obecný lid, patriciát), konfesijní rozrůzněnost a především původ. Již dlouho je známo, že polská města spoutaná šlechtickými privilegii upadala, čímž trpělo měšt’anstvo, pro něž se šlechtická kultura stávala mnohem atraktivnější než vlastní tradice. Pouze větší polská města, zejména pruská (Gdaňsk, Toruň, Elbinky), byla v průběhu 16. a 17. století schopna vzdělávat své politické elity, které se zodpovědně zabývaly obecní správou a vyrovnávaly se se šlechtickými privilegii - což nebylo nijak jednoduché, protože šlechta pohrdala měšt’anstvem ještě víc než selským stavem (základem hospodářského života) jakožto těmi, kteří se zabývají hanebnými profesemi. ${ }^{46}$ Podceňování měst a měšt’anstva šlechtou bylo všeobecně rozšířeno. Vysmívali se jim jako měšt’ákům, ,samet’ákům“ (zamszyki - podle oblečení) a vydřiduchům, dávali jim za vinu drahotu a bohatším vyčítali i život v přepychu. ${ }^{47}$

To ale nijak nebránilo tomu, aby byla měšt’anská mládež vzdělávána s ohledem na předem vyhlédnutá místa a v závislosti na očekávaných sociálních rolích ve městě. Nižší vrstvy i ze svých synů většinou vychovávaly řemeslníky, z kupeckých rodin pocházeli další kupci a handlíri a z patriciátu po předcházejícím absolvování vyššího typu studia představitelé svobodných povolání a městské inteligence (pastoři, učitelé, lékaři, právníci). Nelze opomenout, že díky četným stipendiím, zvláště v pruských městech, se také nadaní mladíci z nižších vrstev mohli zapsat na vysoké školy, a to i zahraniční. ${ }^{48}$ Pruská města, jež si chtěla zajistit vlastní odbornou pracovní sílu, nejenže hojnou rukou rozdávala stipendia, ale byla stipendistům také opakovaně nápomocna materiálně. Student, který se ucházel o roční stipendium, je obvykle získával také na další léta, protože úředníci si byli vědomi toho, že poctivé studium je obtížné přesně časově vymezit. Díky tomu mohl prakticky každý schopný a ambiciózní mladý měšt’an získat dobré vzdělání, jež bylo předpokladem pro akademickou, úřednickou nebo kupeckou kariéru přinášející prestiž a bohatství. V polsko-litevském soustátí měšt’any vzhledem k jejich nízkému postavení v rámci země neuspokojovaly zastávané městské úřady či dosažené akademické grady, poněvadž jejich vliv na podobu státu, v němž i nemajetný šlechtic-analfabet mohl podle práva volit krále nebo se jím přímo stát, byl mizivý. Pouze některá města jako Krakov mohla vysílat na sejmy své posly, ani oni však na nich nemohli veřejně vystupovat.

Výsledkem byla situace, kdy měšt’ané opouštěli vlastní kulturní model a místo toho se přizpůsobovali modelu šlechtickému, což charakterizovala i snaha o získání „šlechtického klenotu“ a odstranění stavovských bariér, zejména v oblastech, kde stavovský původ neměl (nebo alespoň nemusel mít) rozhodující roli, tedy v oblasti umění, vědy nebo vojenství. Bylo to velkým pokušením pro vzdělané a zámožné představitele měšt’anstva, kteří považovali nobilitaci za definitivní cíl svého edukačního a životního modelu, ačkoli snaha měšt’anů o získání šlechtického titulu nikdy nebyla masovým jevem. I tak byla ale chut' měšt’anů k získání erbu dostatečně silná na to, aby soustředili ohromující finanční částky a úsilí, ba dokonce i nelegální prostředky, k tomu, aby získali prŕistup k plnému začlenění mezi př́íslušníky Rzeczypospolité. Valerián Trepka ve své Liber chamorum „,vypátral“ více

46 Stanisław Herbst, Miasta i mieszczaństwo renesansu polskiego, in: S. Herbst (ed.), Potrzeba historii czyli o polskim stylu życia. Wybór pism, I, Warszawa 1978, s. 418.

47 Jan Stanisław Bystroń, Dzieje obyczajów w dawnej Polsce. Wiek XVI-XVIII, Warszawa 1976, s. 192.

48 M. Pawlak, Studia uniwersyteckie, Toruń 1988, s. 50. 
než 1250 příjmí nepravé šlechty rekrutující se z „městských synkư““. ${ }^{49}$ Existovaly ovšem také legální prostředky, jak se stát šlechticem: sňatek s představitelem šlechtického stavu, koupě zemského statku, služba u některého z magnátů, ve vojsku nebo na královském dvoře, případně prostřednictvím vzdělání. Právě vzdělání bylo v tomto ohledu zásadní, bylo-li důsledné a získané $\mathrm{v}$ zahraničí. Měštanům se díky mobilitě a př́slušným konexím otevírala cesta $\mathrm{k}$ nobilitaci nejen $\mathrm{v}$ Polsku, ale i mimo jeho hranice. Př́istup $\mathrm{k}$ vědě a vzdělání byl proto mezi měšt’any jiný než mezi šlechtou. Vzdělání nepředstavovalo dodatečnou podmínku, ale základ k získání odpovídajícího sociálně-politického postavení. ${ }^{50}$

Oproti šlechtě se měšt’anstvo těšilo také lepší dostupnosti vzdělání. Všechny vysoké, vyšší, stř̌ední a kolegiátské vzdělávací ústavy Rzeczypospolité se nacházely právě ve městech, zvláště pruských, takže finanční náklady na studia nebyly pro měšt’anskou mládež obvykle velké. Stačilo být nepř́liš bohatým měšt’anem z Braniewa, aby bylo možno vystudovat tamní jezuitské kolegium, poté se vydat do nedalekého Královce na Albertinu, následně odjet díky př́slušnému stipendiu do zahraničí a po získání akademického gradu se uchytit v kanceláři některého z knížat nebo magnátů a zajistit si šlechtický titul. Pro nejméně majetné př́ślušníky šlechtického stavu byla podobná cesta $\mathrm{k}$ vyššímu vzdělání obvykle nemyslitelná.

Jak je vidět, možnosti získat vyšší vzdělání měli měšt’ané často větší a určitě pro ně byly méně finančně náročné. Měšt’ané se v Polsku přes svou politickou marginalizaci snažili zlepšit své postavení, přičemž nejlepší cestou k úspěchu jim bylo právě vzdělání. Na dalších stranách tohoto pojednání představíme řadu př́ipadů takových cest za vzděláním, jejichž hlavní zastávku představovala pražská univerzita.

\section{Studenti z Rzeczypospolité na pražské univerzitě v 17.-18. století}

Než přejdeme k podrobnému popisu pobytu studentů z Rzeczypospolité na pražské univerzitě, je nutné krátce představit sociálně-politickou situaci Čech i Prahy samotné. Je to otázka zásadního rázu, protože události v Čechách a jejich hlavním městě měly významný vliv na celkový počet studentů pobývajících za jihozápadní hranicí Rzeczypospolité. V momentech, kdy Čechy postihovaly krize různého druhu, zmenšoval se adekvátně i počet polských studentů $v$ Praze, který domácími poměry samozřejmě také ovlivňovaly.

Začátek 17. století byl pro český stát dobou bouřlivých proměn. Trvalé napětí mezi habsburskou dynastií, panující tu od roku 1526, a opozicí, tvořenou nekatolickou šlechtou a měšt’anstvem, nakonec vedlo $\mathrm{k}$ vypuknutí velkého protihabsburského povstání v letech 1618-1620 a k počátku smutně proslulé třicetileté války..$^{51} \mathrm{Jak}$ je dobře známo, povstalci z této konfrontace vyšli poražení a pokoření. Po bitvě na Bílé hoře v roce 1620 Habsburkové odbojné stavy nemilosrdně potrestali. Rozsáhlé konfiskace pozemkového majetku posloužily částečně $\mathrm{k}$ obohacení úředníků zajišt’ujících jejich provedení, částečně vedly k prodeji statků novým majitelům. Hospodářské machinace a emise tzv. „dlouhé mince“

49 Maria Bogucka, Miejsce mieszczaństwa w spoleczeństwie szlacheckim: atrakcyjność wzorców życia szlacheckiego w Polsce XVII wieku, in: Jerzy Wyczański (ed.), Społeczeństwo staropolskie, I, Warszawa 1976, s. 191-192.

50 D. ŻoŁĄDź, Idealy edukacyjne, s. 224.

51 Robert John Weston Evans, Vznik habsburské monarchie 1550-1700, Praha 2003, s. 80. 
způsobily neslýchaný nárůst cen a katastrofální inflaci (vzrůst cen v roce 1623 o 400 \% v porovnání se situací z roku 1616). ${ }^{52} \mathrm{~K}$ tomu přistoupila násilná rekatolizace a s ní spojený odchod řady obyvatel do exilu. ${ }^{53} \mathrm{~V}$ důsledku tzv. „generálního pardonu“ $\mathrm{z}$ dubna 1622 byli potrestáni opravdoví i domnělí protivníci Habsburků, v čele s pražskými měštany, přičemž důkazem viny mohlo být i pouhé placení daní v době povstání. ${ }^{54}$ Německý jazyk byl zrovnoprávněn s češtinou. Vzrostla rezidenční role Vídně a z Prahy, sídelního města císaře Rudolfa II. (1576-1612), se stalo provinční centrum. Válečné zpustošení, hospodářský úpadek, hladomor a rozsáhlá emigrace (kolem 1300 osob jen z pražských měst) ${ }^{55}$ způsobily, že město ztratilo své dávné kouzlo a postavení.

Fatální situace Prahy nalezla odraz i v soudobých relacích. Jiří Ossoliński, polský vyslanec k říšskému sněmu v Řezně v roce 1636, započal záznam ve svém diariu konstatováním: „tak te kilka dni wolatem zatrzymać się w Pradze, lubo z utęsknieniem i kosztem niemałym w tak niestychanej drogości kraju do szczętu spustoszonego"56 (rozhodl jsem se těch několik dní strávit v Praze, ač nerad a s nemalými výdaji při tak neslýchané drahotě v zemi zcela zpustošené). O návštěvě Pražského hradu a katedrály uvedl, že „,mieszkanie królów czeskich jest dosyć skromne i nie ad majestatem" (sídlo českých králů je dost skromné a nikoli odpovídající majestátu), ale ještě je vidět ,po salach jednak i galeryach [...] reliquias Rudolfa cesarza" (po sálech a galeriích [...] pozůstatky po císaři Rudolfovi). Zajímavý je posledně uvedený údaj, zvláště vezmeme-li v potaz následky rabování, četných prodejů a poničení rozsáhlých sbírek císaře Rudolfa II. během třicetileté války. ${ }^{57}$ Ossoliński neopomněl navštívit také hradní stáj, podle jeho dojmu majestátní, jež ,,petna koni jezdnych na ten czas była, nie jednak osobliwego i coby do gustu naszego "58 (byla právě plná jízdních koní, ale nijak zvláštních a podle našeho gusta). Je vcelku zřejmé, že Praha stejně jako celé Čechy byla ve špatném stavu. Odráží se to i na počtu studentů z Rzeczypospolité, který byl v klidnějších dobách výrazně větší, byt' musíme vzít v potaz také to, že pro léta 1624-1640 nám prameny poskytují pouze neúplné údaje.

V roce 1648 navíc došlo k obléhání Prahy švédskými vojsky, což mělo za následek evakuaci cizinců z města, a to včetně polských studentů, kteří vzhledem $\mathrm{k}$ těžké situaci doma (povstání Bohdana Chmelnického, smrt krále Vladislav IV.) Prahu opouštěli i dobrovolně. Následující desetiletí v dějinách Čech a Prahy proběhla ve znamení barokního absolutismu a hospodářského systému, opřeného o vrchnostenské velkostatky. Země se pomalu začínala zotavovat z tě̌̌kých desetiletí, o čemž svědčí také relace z pobytu syna innowrocławského podkomořího Jana Tuczyńského v Praze v prosinci roku 1655, když se po ročním pobytu v jezuitské koleji v Ingolstadtu rozhodl navštívit Čechy. V Praze pobýval několik týdnů.

Nebude bez užitku shrnout celou relaci, abychom si přiblížili charakter města $\mathrm{v}$ době, kdy zde pobýval největší počet studentů z Rzeczypospolité. Tuczyński cestoval s třemi společníky, včetně kněze Steczewicze, který měl ostatní během cesty na starosti a pečlivě

52 Ivana ČornejovÁ - Jiří KaŠe - Jiří Mikulec - Vít Vlnas, Velké dějiny zemí Koruny české, VIII, 1618-1683, Praha - Litomyšl 2008, s. 88-89.

53 Tamtéž, s. 90-91.

54 Josef JANÁČEK, Dzieje Pragi, Warszawa 1977, s. 225.

55 Otto Placht, Lidnatost a společenská skladba českého státu v 16.-18. století, Praha 1957, s. 107-108.

56 A. Hirschberg (ed.), Dyaryusz legacyi, s. 11. Tento citát z původního pramene, stejně jako všechny následující, byl ponechán v původním znění.

57 Josef JANÁČEK, Rudolf II a jeho doba, Praha - Litomyšl 2003, s. 523-526.

58 A. Hirschberg (ed.), Dyaryusz legacyi, s. 13. 
Tabulka 1: Počet studentů z polsko-litevského soustátí na pražské univerzitě v letech $1600-1790$

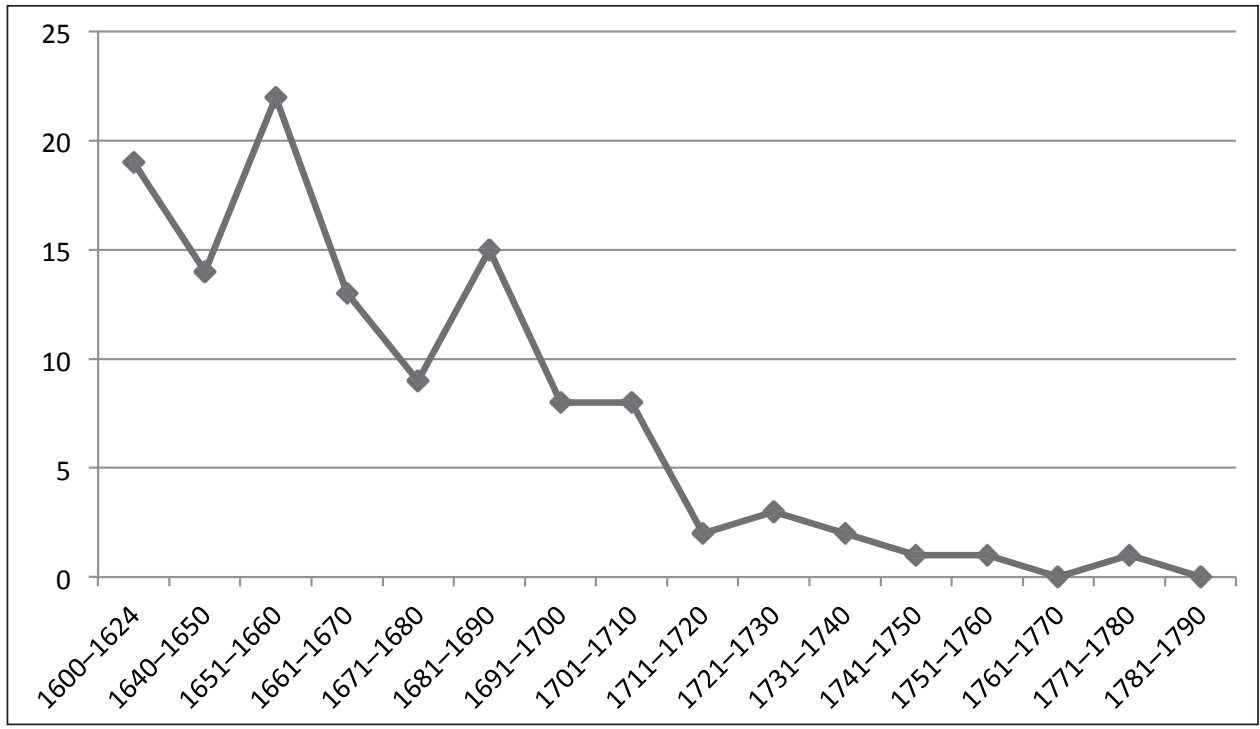

Zpracováno na základě matrik: AUK, f. Matriky, M 63, M 12, M 22; seznamů promovaných: AUK, f. ÚT KFU, I (1624-1690, 1650-1690), bez č. (1673-1690), II (1690-1697), III (1697-1701), IV (1701-1705), V (1705-1710), VI (1710-1716), VII (1716-1720), VIII (1720-1725), IX (1725-1729), X (1729-1733), XI (1733-1739), XII (1739-1805); a edic: K. BerÁNEK (ed.), Magistri, baccalaueri; TÝž, Acta facultatis philosophicae.

zapisoval veškeré výdaje. Nejprve se ubytovali v hospodě, kde měli platit 5 zlatých denně. Když zjistili, že je to zbytečně drahé, nalezli levnější hospodu naproti kostelu svatého Jiljí, kde platili pouze 20 zlatých za týden. Objev tohoto místa bylo zásluhou jednoho z místních Židů. Židovské obyvatelstvo v Praze bylo velmi početné $(10000)$ a zajišt'ovalo ve městě různé služby. ${ }^{59}$ Tuczyński během svého pobytu vykonal a přijal řadu návštěv, mezi nimiž byli také jezuité a dokonce „primus profesor praskiej akademii“", ačkoli neuvádí, o jakého profesora konkrétně se jednalo. ${ }^{60} \mathrm{U}$ mladého šlechtice se často scházela společnost, nebot' jak víme z pramenů - brzy bylo třeba zakoupit vědro lepšího vína $\mathrm{v}$ ceně 20 zlatých, opět

59 Tomáš PĚKnÝ, Historie Židi̊ v Čechách a na Moravě, Praha 2001, s. 83-87.

60 Antoni Danysz, Młodzi Tuczyńscy w kolegium jezuickiem w Ingolsztadzie w latach 1654-1659, in: A. Danysz (ed.), Studia z dziejów wychowania w Polsce, Kraków 1921, s. 246. Antoni Danysz použil rukopis kněze Steczewicze (Sumaryusz wszystkiej percepty $i$ expensy w obcych krajach pod czas peregrynacyey Jegomości Pana Jana z Tuczna Tuczyńskiego, podkomorzyca inowrocławskiego, dysponowany przez mię X. Jana Kazimierza Steczewicza...), který obsahoval na 92 listech podrobný výčet výdajů vynaložených během studií mladého Tuczyńského a byl uložen v Knihovně Společnosti př́a lel vědy v Poznani (Towarzystwo Przyjaciół Nauk w Poznaniu). Rukopis se bohužel po 2. světové válce ztratil, není tedy možné podat podrobnější popis pobytu Tuczyńského v Praze. Srov. Bernard Olejniczak - Joanna Pietrowicz (edd.), Inwentarz rękopisów Poznańskiego Towarzystwa Przyjaciół Nauk (sygn. 1-1950), Warszawa 2008, s. 861. 
prostřednictvím místního Žida. Není bez zajímavosti, že cena vína, nápoje pro studenty tak důležitého, byla tehdy v Praze srovnatelná s cenami na území Rzeczypospolité. ${ }^{61}$ Kromě hodování se polští hosté věnovali také prohlídce města, zvláště kostelů, kde jako průvodci nezř́ídka sloužili chudí studenti. Svátky Narození Páně trávili v Praze, ale o podobě Štědrého večera se pramen nezmiňuje. Po prohlídce kláštera cisterciáků na Zbraslavi, zaplacení služeb Židům a hospodyni, včetně platu za „kieliszki, które Jegomość pottukt“" (skleničky, které J. M. rozbil), opustili na Silvestra Prahu. ${ }^{62}$

Podoba Prahy a Čech celkově se rovněž měnila. Výrazné zvětšení majetku církve po roce 1620 vedlo k zintenzivnění jejích fundačních aktivit. Vzniklo větší množství farností, byly přestavěny již existující kostely a kláštery. Nové budovy byly stavěny a staré upravovány v barokním stylu. Praha získávala novou tvár. Městu začala dominovat monumentální barokní architektura a tón udával klérus s katolickou šlechtou. ${ }^{63}$ Odráží se to mimo jiné v diariu Teodora Billewicze erbu Mogiła, mladého stolníka žmud'ského, ${ }^{64}$ který se v roce 1677 vydal na roční cestu po Evropě. Připojil se k výpravě knížete Michala Kazimíra Radziwiłła, litevského místokancléře a litevského polního hejtmana, a jeho ženy Kateřiny Sobieské, sestry krále Jana III., s nimiž měl možnost navštívit také Prahu. Jeho relace o pobytu ve městě je tím zajímavější, že ji popisoval z perspektivy čerstvého absolventa filozofie na vilenské akademii - jeho pohled na pražskou realitu byl tedy určitě podobný jako u většiny studentů z Rzeczypospolité, kteří přišli do Prahy. Stojí tedy za to uvést celou jeho zprávu o zdejším pobytu: „Przed sama Praga, po raz pierwszy tak wielka liczbę winnic obfitych widzieliśmy, z których wina czeskie robia, jako się i dobre udaja. Miasto same. Wjechaliśmy do miasta przed wieczorem godzinę, najokazalej, tak iz lud ze wszystkich stron napływat dla widzenia wjazdu księcia Jego Mości, a że wozy, wielbłady i rumaki godzina wprzód przyszli, ściagnęly ich na widowisko. Przejechawszy wtedy jedna stronę miasta (bo podzielone jest na dwie części bardzo potężna rzeka przeplywajaca środkiem tych miast) jechaliśmy przez most na tej rzece, który jest tak dtugi, jako na czworo z tuku strzelania, ale bardzo mocny i gruntowny, tak iż przez starość i nieprzerwany ludzi przechodzenie kamienie poboczne na pót tokcia i dále, we środku tych kamieni potężnych doły wydeptaty się. Na środku tego mostu jest krucyfiks wielka struktura wyrobiony. U którego nieprzerwanie we dnie i w nocy lampa gore i co wieczór akademicy litanie pod nim klęczac śpiewaja. Na tę pamiątkę ten krucyfiks wznosi się, iż kiedy Szwed podstępnie byt jednej nocy Pragi jedna część opanowat, jezuici (którzy mają bardzo wielka magnificencją kościót i klasztor niedaleko od tego mostu na drugiej stronie), zebrawszy akademików opanowali się na połowie mostu, do których dołaczyt lud, dtugo się bronili i nie dali sobie drugiego miasta wziąć. Widzac tedy Szwed, iz to sasiedztwo z obu stron nie bardzo wyglada, tak sita rzeczy ustapili. Za co jezuitom i akademikom wielkie prawa i przywileje cesarz nadat. A na tym miejscu

61 V letech 1654-1660 stálo vědro vína, tedy přibližně 5,5 hrnce (garniec = cca. 3,77 1), 18 zlatých v Lublině, 13 zlatých v Krakově a 18 zlatých ve Varšavě, takže cena vína v Praze nebyla př́liš vysoká, zvláště vezmeme-li v úvahu, že Tuczyński koupil „,dobre wino“, a cena v Rzeczypospolité je počítána za běžné víno. Podle: Władysław ADAmCzyk, Ceny w Lublinie od XVI do końca XVIII wieku, Lwów 1935, s. 78; Edward TomASzEwSKI, Ceny $w$ Krakowie $w$ latach 1601-1795, Lwów 1934, s. 61; Władysław AdAMCZYK, Ceny w Warszawie w XVI i XVII wieku, Lwów 1938, s. 29-30.

62 A. Danysz, Młodzi Tuczyńscy, s. 246.

63 J. JANÁČEK, Dzieje Pragi, s. 250-252.

64 Michał Bernsztejn, Billewicz Teodor, in: Władysław Konopczyński (ed.), Polski Słownik Biograficzny, II, Kraków 1936, s. 101-102; Adam BonIECKI, Herbarz polski, I, Warszawa 1899, s. 266. 
mostu, na którym się oni kolokowali, tę pamiatkę wystawiono. Kiedy przejechaliśmy przez most, niedaleko od niego wjechaliśmy równo z zmrokiem do gospód naznaczonych jako księżni, tak też i catemu dworowi.

Nazajutrz jechało publicznie księstwo z kalwakata do zamku do kościoła na msza, stuchali mszy w kaplicy, gdzie ciało św. Wactawa leży. Po mszy prezentowano relikwie, których jest nie mało. Między innymi: piersi św. Anny calusieńkie w krysztale, głowa św. Stefana męczennika pierwszego, głowa św. Jana Chrzciciela, innych wiele. Potem przegladaliśmy pokoje w zamku i skarbiec, gdzie różne rzadkości pokazywano nam. Między innymi krokodyle, więdle syreny, różne bestie morskie niesamowite, lamparta żywego, który jest z natury najdzikszym zwierzem. Jakośmy z ganku wysokiego patrzyli tedy skakat aż pod ów ganek, chcac schwycić kogo, ale że niepodobna rzecz kratę tak wysoko dobyć się, nic nie szkodzit nikomu.

Dnia 15 Octrobris, w dzień św. Teresy, nabożeństwa księstwo IM stuchali u mniszek reguby tejże św. Teresy, gdzie po nabożeństwie u forty księstwo IM byli. Mniszki prezentowaty za krata jedna już od lat trzydziestu umarła, bardzo pobożnego żywota mniszkę, calusieńka i teraz jak żywa siedzaca.

Stamtąd wróciwszy jechaliśmy oglądać pałace, które sa bardzo specjalne, mianowicie $d w a$. Jeden już ukończony Wallensteinów, bardzo wspaniała budowla jako w pokojach, tak też w innych galanteriach. Sala niestychanie wysoka i specjalna. Ogrody wtoskie na ptactwo dostatnie i przestronne kraty, rybnice w ogrodzie dla delektowania się, skaty a że robione na wzór natury, tak wyrażone, iż żadnym sposobem odróżnić od prawdziwych wzrokiem nie moga. I w inne wiele dla przyjemności należace specjały, dość bogaty. Drugi zaś jeszcze nie ukończony niejakiego pana grafa Czernina, także wielkim kosztem i magnificencja jest wznoszony.

Dnia 18 także publicznie w kościele księstwo Ich Mościowie byli u jezuitów, tam mszy i nabożeństwa stuchali. Po nabożeństwie różne relikwie pokazano: głowę św. Urszuli, kapelusz św. Ksawerego i palec, i innych niemało, głowe św. Barbary, etc.

Miasto same jest $i$ wielkie, i ozdobne, jako w kościoly, w klasztory i kamienice bogate. W którym tydzień wymieszkawszy, codziennie muzyk różnych, komedii uciesznych, uciech zażywają wyjechaliśmy z Pragi dnia 20 Octobris ku Norembergowi“ ${ }^{\text {“' }} .5$

(Před samotnou Prahou jsme poprvé viděli množství rozlehlých vinic, z nichž se připravují česká vína, jež se vydaří i velmi dobrá. Samotné město. Vjeli jsme do města hodinu před večerem, co nejokázaleji, takže se lidé hrnuli ze všech stran, aby viděli př́ijezd J. M. knižete, a také je $\mathrm{k}$ té podívané přitáhli velbloudi a koně, kteří přišli už o hodinu dř́ive. Když jsme projeli jednu stranu města (nebot' je rozděleno na dvě části velmi mohutnou řekou plynoucí prostředkem oněch měst), přejeli jsme přes řeku po mostě, který je dlouhý na čtverý dostřel z luku, ale velice pevný a masivní, takže stárím a neustálým přecházením lidí přes boční kameny na půl lokte i dále se $\mathrm{v}$ těch mohutných kamenech vyšlapaly dolíky. Uprostřed tohoto mostu je nákladně vybudovaný křiž. U něj svítí nepřetržitě ve dne v noci lampa a akademici klečíce zpívají litanie. Kř̌ž tu stojí na památku toho, když Švéd jedné noci úskokem opanoval jednu část Prahy a jezuité (kteří mají nedaleko tohoto mostu na druhé straně nádherný veliký kostel a klášter) sebravše akademiky, k nimž se připojil lid, opevnili se v polovině mostu, dlouho se bránili a nedali si druhou polovinu města vzít. Když

65 BK PAN, rkps. BK 386, Mf. 358, s. 3r-3v. 
tedy Švéd viděl, že to na sousedství obou stran př́liš nevypadá, pod tlakem skutečnosti ustoupil. Za což udělil císař jezuitům i akademikům velká práva a privilegia. A na místě, kde se střetli, byla vystavena tato památka. Když jsme přejeli přes most, vjeli jsme nedaleko od něj do hostince určeného jak pro kněžnu, tak pro celý dvůr.

Nazítři jela knížata slavnostně s průvodem na hrad na mši do kostela a vyslechla mši v kapli, kde leží tělo sv. Václava. Po mši byly ukazovány relikvie, jichž je nemálo. Mezi jinými: prsa sv. Anny celičké v křištélu, hlava sv. Štěpána prvomučedníka, hlava sv. Jana Křtitele a mnoho jiných. Potom jsme si prohlíželi místnosti na hradě a klenotnici, kde nám ukazovali různé vzácnosti. Mimo jiné krokodýly, seschlé sirény, různé zvláštní mořské šelmy a živého levharta, který je od prírody nejdivočejším zviřretem. Když jsme se dívali z vysokého balkónu, tak skákal až pod onen balkón a chtěl někoho zachytit, ale protože nebylo možné, aby se přes mříž dostal tak vysoko, nikomu nijak neuškodil.

Dne 15. Octobris, na den sv. Terezy, se J. M. knížata účastnila bohoslužby u mnišek řádu sv. Terezie, a po bohoslužbě byly J. M. u fortny. Za mř́žíi ukazovaly mnišky jednu již třicet let mrtvou, za života velice zbožnou mnišku, celičkou a nyní sedící, jako by byla živá.

Navrátivše se odtamtud jeli jsme si prohlédnout paláce, které jsou opravdu mimořádné, zejména dva. První, již dokončený, patřící Valdštejnům, velice krásná budova jak co do pokojů, tak textilií. Sál je nebývale vysoký a zvláštní. Vlašské zahrady, okázalé a prostorné klece na ptactvo, rybníčky $\mathrm{v}$ zahradě pro potěšení a [umělé] skály upravené podle prrírody tak, že je na pohled nebylo možné od pravých rozeznat. I na jiné k potěšením náležející zvláštnosti je [zahrada] dosti bohatá. Druhý palác, dosud nedostavěný, jakéhosi pana hraběte Černína, je také vystavěn velmi nákladně a vznešeně.

Dne 18. [Octobris] byla J. M. knížata veřejně v kostele u jezuitů, kde poslouchala mši a bohoslužbu. Po bohoslužbě byly ukazovány různé relikvie: hlava sv. Uršuly, klobouk a prst sv. Xavera a nemálo dalších, hlava sv. Barbory atd.

Samotné město je veliké a zdobné, bohaté na kláštery a domy. V němž přebyvše týden a uživaje denně různých koncertů, veselých komedií a radostí, vyjeli jsme z Prahy dne 20. Octobris k Norimberku.)

Popis Teodora Billewicze je důkladný a barvitý. Podobný styl prezentace měst navštívených družinou knížete Radziwiłła je typický i pro další část diaria. Billewicz se soustředil na památky, kostely, kláštery a místní zajímavosti. Jediným rozdílem mezi popisem Prahy a jiných měst je absence popisu fortifikačního systému pražských měst, která je v př́padě jiných lokalit vždycky důkladná. Z toho je možné usoudit, že pro Billewicze nebyla Praha v tomto ohledu atraktivní a její obranný systém se mu jevil spíše jako slabý.

Poměrně klidná vnitropolitická situace v Čechách druhé poloviny 17. a 18. století umožnila ekonomický rozvoj, změny v hospodářství a vznik průmyslové výroby. Je zajímavé, že počet polských studentů v Praze přesto drasticky klesá, a to soustavně od roku 1660 s výjimkou let 1671-1680 a 1691-1700, což lze vysvětlit pouze nepríznivými poměry a těžkou vnitropolitickou situací v polsko-litevském soustátí (vláda krále Michala Wiśniowieckého, sled válek a úpadek státu za krále Stanislava Augusta Poniatowského). Ani Čechy nebyly ušetřeny válečných událostí v podobě slezských válek (1740-1763) a sedmileté války (1756-1763), vedoucích ke ztrátě strategického Slezska. Praha byla dvakrát obléhána a v letech 1741-1742 obsazena, přičemž během obléhání v roce 1757 Prusové zničili třetinu domů ve městě a vážně poškodili Pražský hrad. Tato nebezpečí společně s katastrofální situací v Rzeczypospolité způsobila, že na pražské univerzitě od roku 1731 
kromě sporadických jednotlivých př́ípadů polské studenty takřka nenacházíme. Spolupůsobila tu jistě také skutečnost, že Vídeň jakožto hlavní město monarchie byla atraktivnější a skýtala lepší perspektivy, zvláště vezmeme-li v úvahu její rostoucí hospodářskou a politickou roli v centralizovaném absolutistickém státě i během tereziánských a josefínských osvícenských reforem. ${ }^{66}$ Tento vývoj potvrdil provinční charakter Prahy a celého Českého království. Vnějším výrazem této situace bylo i uložení českých korunovačních klenotů ve Vídni, přestavba Pražského hradu s důrazem na obranné prvky i výprodej a zničení toho, co zůstalo ze sbírek Rudolfa II. ${ }^{67}$ Přes to všechno se v oblasti ekonomiky a kultury objevily vzestupné tendence. Vzrostl počet obyvatelstva - v samotné Praze žilo v roce 1771 na 80000 obyvatel, což je sice oproti 193 tisícům obyvatel Vídně výrazně méně, ale zároveň dvojnásobek oproti stavu na začátku 18. století. Rozvíjí se sít' manufaktur, obchod a řemeslná produkce. Zrušení jezuitského řádu v roce 1773 přispělo $\mathrm{k}$ odstranění bariér při šíření osvěty a kultury. ${ }^{68}$ Čechy vykročily na cestu přeměn a víceméně klidného rozvoje pod dohledem vídeňského dvora, což kontrastuje se situací polsko-litevského soustátí na konci 18. století, která vedla až $\mathrm{k}$ jeho rozdělení do tří záborů. V následujících desetiletích se studenti polského původu objevují na pražské univerzitě jen sporadicky, a když, tak jako nedobrovolní obyvatelé jiných státních útvarů, nikoli polského státu.

\section{Teritoriální původ}

Studenti z Rzeczypospolité, kteří přijeli studovat do Prahy, již nemohou nadále zůstávat $\mathrm{v}$ anonymitě. Než je ale představíme jmény, je na místě nastínit jejich teritoriální původ. Jedná se o závažný aspekt, jenž nám umožní odpovědět na otázku, z které lokality a regionu polsko-litevského soustátí pocházel největší počet pražských akademiků polského původu. Rozbor teritoriálního původu nám také pomůže objasnit některé aspekty motivace, která dotyčné ke studiu na pražském vysokém učení vedla. Jisté závěry jsou samožrejmě snadno prèedvídatelné, a sice že největši počet studentů pocházel ze západních nebo jihozápadních polských vojvodství. Blízkost cílové destinace tedy byla nejpravděpodobnějším důvodem vedoucím k výběru Prahy.

Záznamy v matrikách pražské univerzity obsahují kromě jména a př́́domku také údaj o místě původu dotyčného studenta a jeho národnosti. $V$ otázce národnosti (v dobovém smyslu toho slova) dnes nemáme větši problémy s údaji o tom, kdo z jaké oblasti pocházel. Pro studenty z území Rzeczypospolité byla k dispozici označení typu: Polonus, Pruthenus, Samogita, Borusius nebo Lithuanus. V př́padě označení Borusius nebo Pruthenus je teprve podle místa původu možné stanovit, zda dotyčný pocházel z Královských nebo Knížecích Prus. Větší nesnáze se objevují v případě určení přesné lokality. Údaj o místě původu studenta nebyl uváděn $\mathrm{v}$ originální podobě, ale $\mathrm{v}$ latinské, respektive latinizované formě polštiny nebo němčiny. ${ }^{69}$ Tak jsou tedy např́íklad pro osoby pocházející z Gdaňsku používány

66 Stefan Ciara, Czechy w czasach nowożytnych. Od suwerenności do dziedzicznej prowincji Habsburgów, in: Michał Kopczyński - Wojciech Tygielski (edd.), Rzeczpospolita - Europa XVI-XVIII wiek. Próba konfrontacji, Warszawa 1999, s. 132.

67 J. JANÁČEK, Rudolf II, s. 526.

68 TÝž, Dzieje Pragi, s. 262-263.

69 M. MošKoř, Skladba a uplatnění inteligence, s. 89. 
termíny Gedaniensis, Dantisco, Dantiscanus, pro studenty z Dobrého Miasta (dř́ve Guttstadt) Guttstadiensis a Schwentzkowiensis pro rodáky z velkopolské obce Święciechowa (Schwetzkau). Výsledná podoba záznamu závisela na písaři zapisujícím do matriky a jeho pečlivosti, protože se někdy omezil pouze na uvedení provincie, z níž student pocházel, napríklad Masowita, ducatu Podlasiensi nebo Maiori Polonia. Některé záznamy jsou natolik zdeformované, že identifikace místa původu studenta není možná. Bylo to způsobeno tím, že úředníci většiny evropských univerzit, což jistě platilo i pro Prahu, zapisovali do matrik bud' podle sluchu, nebo podle předem připravených poznámek, které někdy sestavovali až dodatečně a rovněž na základě ústního prohlášení studenta. ${ }^{70}$

Přesto se část lokalit podařilo na základě prí́domků studentů šlechtického původu identifikovat, a to v př́ípadech, kdy bylo rodové sídlo nadále ve vlastnictví téhož rodu (Zakrzewski z Zakrzewa, Wiśniowski z Wiśniowa, Lewicki z Lewiczyna). I tak ale bylo nutné se v př́padě části př́slušníkủ akademické obce z řad šlechty omezit na uvedení širšího místa původu (vojvodství). Také zde zůstávají některé otazníky, protože nebylo možné jednoznačně určit místo původu Michala Korybuta Wiśniowieckého, Kryštofa Antonína Szembeka nebo jednoho utečence $\mathrm{z}$ východních provincií Rzeczypospolité. $\mathrm{V}$ takových prípadech bylo do statistiky zahrnuto vojvodství, v němž se narodili, př́ípadně kde dospívali. U patnácti studentů se přesto nepodařilo oblast původu určit vůbec. Toto číslo představuje patnáct procent $\mathrm{z}$ celkového počtu polských studentů pražské univerzity známých jménem a doložitelných v pramenech (nepočítaje $\mathrm{v}$ to devatenáct studentů nalezených historikem Henrykem Baryczem).

Tabulka 2: Teritoriální původ studentů z polsko-litevského soustátí

\begin{tabular}{|l|l|c|}
\hline \multicolumn{2}{|c|}{ Korunní země (54 studentů) } \\
\hline \multicolumn{1}{|c|}{ provincie } & \multicolumn{1}{|c|}{ místo } & počet studentů \\
\hline Vojvodství sieradzské & Miłkowice & 1 \\
\hline Vojvodství mazoviecké & Ciechanów & 1 \\
& Lewiczyn & 1 \\
& Kubra & 1 \\
& Warszawa & 3 \\
\hline Mazovsko & - & 1 \\
\hline Vojvodství krakovské & Chrzanów & 1 \\
& Niegowa & 1 \\
& Częstochowa & 2 \\
\hline Vojvodství lublinské & Płonki & 1 \\
& Wiśniów & 1 \\
\hline Vojvodství poznaňské & Święciechowa & 14 \\
& Wschowa & 1 \\
& Czaplinek & 1 \\
& Leszno & 1 \\
& Zbąszyń & 1 \\
& Rakoniewice & 1 \\
\hline
\end{tabular}

70 M. Снаснал, Metryki zagranicznych uniwersytetów, s. 42. 


\begin{tabular}{|c|c|c|}
\hline Vojvodství kališské & $\begin{array}{l}\text { Zakrzewo } \\
\text { Bieganin } \\
\text { Żerków } \\
\text { Bnin } \\
-\end{array}$ & $\begin{array}{l}2 \\
1 \\
1 \\
1 \\
2\end{array}$ \\
\hline Velkopolsko & - & 2 \\
\hline Vojvodství ruské & $\begin{array}{l}\text { Pogórze } \\
\text { Zamość } \\
\text { Bílý Kámen } \\
\text { - }\end{array}$ & $\begin{array}{l}1 \\
1 \\
1 \\
1\end{array}$ \\
\hline Vojvodství sandoměřské & $\begin{array}{l}\text { Brzezie } \\
\text { Radom }\end{array}$ & $\begin{array}{l}1 \\
1\end{array}$ \\
\hline Vojvodství podleské & $\begin{array}{l}\text { Piętkowo } \\
-\end{array}$ & $\begin{array}{l}1 \\
1\end{array}$ \\
\hline Vojvodství inovroclavské & Szczepanowo & 1 \\
\hline Vojvodství ravské & Jamno & 1 \\
\hline \multicolumn{3}{|c|}{ Prusko (23) } \\
\hline provincie & místo & počet studentů \\
\hline Vojvodství pomořské & $\begin{array}{l}\text { Gdańsk } \\
\text { Oliwa }\end{array}$ & $\begin{array}{l}5 \\
1\end{array}$ \\
\hline Vojvodství malborské & Elbląg & 1 \\
\hline Knížectví varmijské & $\begin{array}{l}\text { Braniewo } \\
\text { Pieniężno } \\
\text { Dobre Miasto } \\
\text { Reszel } \\
\text { Kronowo } \\
\text { Olsztyn }\end{array}$ & $\begin{array}{l}4 \\
1 \\
3 \\
3 \\
1 \\
1\end{array}$ \\
\hline Knížecí Prusy & Królewiec & 1 \\
\hline bez bližšího určení & - & 2 \\
\hline \multicolumn{3}{|c|}{ Velkoknížectví litevské (5) } \\
\hline provincie & místo & počet studentů \\
\hline Vojvodství vilenské & $\begin{array}{l}\text { Wilno } \\
-\end{array}$ & $\begin{array}{l}1 \\
2\end{array}$ \\
\hline Vojvodství brestsko-litevské & Tuczna & 1 \\
\hline Vojvodství žmud'ské & Szymonwice & 1 \\
\hline \multicolumn{3}{|c|}{ bez bližšího určení (18) } \\
\hline
\end{tabular}

Zpracováno na základě matrik: AUK, f. Matriky, M 63, M 12, M 22; seznamů promovaných: AUK, f. ÚT KFU, I (1624-1690, 1650-1690), bez č. (1673-1690), II (1690-1697), III (1697-1701), IV (1701-1705), V (1705-1710), VI (1710-1716), VII (1716-1720), VIII (1720-1725), IX (1725-1729), X (1729-1733), XI (1733-1739), XII (1739-1805); edic: K. BerÁneK (ed.), Magistri, baccalaueri; TÝŽ, Acta facultatis philosophicae; erbovních knih: A. BonIecki, Herbarz Polski, II, IV, V, VII, IX, X, XIII, XIV, Warszawa 1900-1902, 1904, 1906-1907, 1909, 1911; Jan Karol DACHNOwsKi, Herbarz szlachty Prus Królewskich 
z XVII wieku, ed. Zdzisław Pentek, Kraków 1995; K. Niesiecki, Herbarz Polski, IV, V, VII-IX, Lipsk 1839-1842; S. URUSKI, Rodzina. Herbarz szlachty polskiej, I, IV, VI-VIII, XI, XIV, XV, Warszawa 1904, 1907, 1909-1911, 1914, 1917, 1931; Teodor ŻYchliński, Złota ksiega szlachty polskiej, I, V, Poznań 1879, 1883; Ludwik Korwin, Ormiańskie rody szlacheckie, Kraków 1934; a slovníku: Filip Sulimierski - Bronisław Chlebowski - Władysław Walewski - Ludwik KrzYwicki (edd.), Stownik geograficzny Królestwa Polskiego i innych krajów słowiańskich, I-XV, Warszawa 1880-1902.

Souhrnný pohled na teritoriální původ studentů z Rzeczypospolité na pražské univerzitě se jeví následovně. Ze samotných korunních zemí (Korona) pocházelo padesát čtyři studentů. Nejvíce jich přišlo z Velkopolska (30), z toho přes dvě třetiny (21) z měst a obcí v Poznaňském vojvodství: Święciechowa (14), Wschowa (2), Czaplinek (1), Lešno (1), Zbąszyn (1), Rakoniewice (1) a jeden uvedený v matrice obecně jako „ex palatinatu Poznaniensi ${ }^{\text {“. }}$ Kališské vojvodství bylo zastoupeno sedmi studujícími: Zakrzewo (2), Bieganin (1), Żerków (1), Bnin (1), přičemž ve dvou prípadech bylo uvedeno pouze „ex Calisiensi palatinatu“. Oblast původu posledních dvou studentů z Velkopolska byla označena jednoduše: ,ex Maiori Polonia“.

Z Vojvodství mazovieckého přišlo do Prahy šest studentů, konkrétně z Ciechanowa (1), Lewiczyna (1), Kubry (1) a samotné Varšavy (3). Podobně jako v př́ípadě Velkopolska byl jeden student označen jako „Masovita“. Z Krakovského vojvodství pocházely čtyři osoby, jejichž místy původu byl Chrzanów (1), Niegowa (1), Częstochowa (2). Z Ruského vojvodství ${ }^{71}$ přišli do Prahy rovněž čtyři studenti: Pogórze (1), Zamość (1), dále v Bílém Kameni (dnes Білий Камінь, Ukrajina) narozený a tamtéž vychovávaný Michal Korybut Wiśniowiecki72 a jeden šlechtic, který v tomto vojvodství vlastnil pozemkový majetek. Dále po dvou studentech ze Sandoměřského vojvodství: Brzezie (1) a Radom (1), Lublinského: Płonki (1), Wiśniów (1) a Podleského: Piętków (1) a bez uvedení lokality (ex ducatu Podlasiensi). Sieradzské vojvodství bylo zastoupeno pouze jedním studentem z Miłkowic, podobně jako Ravské vojvodství, odkud přišel do Prahy jeden student původem z Jamna. Posledním studentem pocházejícím z korunních zemí byl Kryštof Antonín Szembek, narozený ve Szczepanowie v Inovroclavském vojvodství a začínající tamtéž svou kariéru duchovního. ${ }^{73}$

Prusy jsou oproti tomu zastoupeny skupinou čítající dvacet tři studentů. Jeden z nich pocházel z Knížecích Prus, přesněji z Královce, a po celý svůj život byl mnohem více svázán s polským královstvím. Navíc byl držitelem šlechtického titulu, který jeho rodině udělil polský král (řeč je o Jeronýmu Rothovi), ${ }^{74}$ proto pouze on byl zahrnut do naší statistiky. Z Královce sice pocházeli ještě čtyři další studenti, ti ale studovali až poměrně dlouho po roce 1657, tedy v době, kdy Knížecí Prusy už nebyly ani lénem Rzeczypospo-

71 Vojvodství „ruské“ s centrem ve Lvově se nacházelo po obou stranách současné polsko-ukrajinské hranice. Jednalo se o oblasti osídlené ukrajinským/rusínským obyvatelstvem.

72 Adam PrzyBoś, Michat Korybut Wiśniowiecki 1640-1673, Kraków 2007, s. 25.

73 Stanisław Kossakowski, Monografie historyczno-genealogiczne niektórych rodzin polskich, III, Warszawa 1872 , s. $263-265$.

74 Tadeusz Oracki, Stownik biograficzny Warmii, Mazur i Powiśla, od połowy XV w. do 1945 roku, Warszawa 1965, s. 244-246; Tadeusz Oracki, Słownik biograficzny Warmii, Prus Ksiązęcych i Ziemi Malborskiej, I, Olsztyn 1984, s. 118-120. 
lité. Ostatní pocházeli z Královských Prus, ponejvíce z Varmijského knížectví (13), a to z následujících lokalit: Braniewo (4), Pieniężno (1), Dobre Miasto (3), Reszel (3), Kronowo (1) a Olsztyn (1). Šest dalších pocházelo z Pomořského vojvodství, a sice z Gdaňska (5) a Olivy (1). Pouze jeden Prus pocházel z Elbink v Malborském vojvodství. U dvou studentů se podařilo pouze zjistit, že byli pruského původu.

Je takřka samozřejmé, že z Velkoknížectví litevského, od Prahy nejvíce vzdáleného, pocházel nejmenší počet studentů. Bylo jich pět, z toho tři z Vilenského vojvodství - jeden prímo z Vilna, dva z jiných míst (Andrzej Kazimierz Wacław Kuropatnicki, Marcjan Junosza Szaniawski). ${ }^{75}$ Ze zbývajících pocházeli dva z Brestsko-litevského vojvodství, konkrétně z Tuczna (1) a jeden z Szymonowic v Knížectví žmud'ském.

Je tedy zjevné, že v otázce výběru místa studií hrála zásadní roli vzdálenost od domova. Tím lze přesvědčivě vysvětlit dominanci studentů ze západních a jihozápadních vojvodství a v poměru $\mathrm{k}$ jejich počtu jen malý zlomek osob ze severozápadních oblastí Polska a z Velkoknížectví litevského. Prusy jsou výjimkou díky mnohem větší hustotě urbánní sítě a z toho plynoucí větší akademické mobilitě obyvatelstva. Také stojí za zmínku, že z akademických center Rzeczypospolité nejsou zachyceni takřka žádní studenti - z Krakova vůbec žádný, z Královce pouze Jeroným Roth, který ale podle matrik Albertiny na domácí univerzitě vůbec nestudoval. Z Vilna pocházel jeden (Jan Kazimierz Schauer de Augenburg) a ze Zamośče také jeden (Jan Auxentius Owaszinowic). U studenta z Vilna není zřejmé, zda studoval také na tamní akademii, byl s ní ale svázán prostřednictvím svého otce, profesora civilního práva. ${ }^{76}$ Owaszinowic zase studoval na Akademii v Zamości teprve po návratu z Prahy. ${ }^{77}$

\section{Sociální původ}

Rekonstrukce sociálního původu studentů z Rzeczypospolité na pražské univerzitě naráží na podstatně méně těžkostí než popis jejich teritoriálního původu. Vyplývá to ze skutečnosti, že písaři pravidelně zaznamenávali, zda byl dotyčný student šlechticem nebo k tomu podávali alespoň dostatečně významné indicie. Nejčastěji bylo před jménem dopisováno slovo nobilis nebo ve zkrácené verzi nob. Kromě toho se po příjmí anebo před ním uvádělo místo původu dotyčného studenta pomocí předložek $a$, de, př́ípadně von, což ve všech prípadech označovalo šlechtický původ studenta (napríklad: de Kubra Gratski, de Junosza Szaniawski, Plonsky a Plonska, von der Pügsasau). V nemnoha př́padech dostatečně svědčila o vysoce urozeném původu studenta označení jako comes nebo eques. Díky tomu se podařilo zjistit šlechtický původ u třiceti tří studentů. U dalších sedmi, u nichž byla

75 Adam Boniecki, Herbarz Polski, II, IV, V, VII, IX, X, XIII, XIV, Warszawa 1900-1902, 1904, 1906-1907, 1909, 1911, zde XIII, s. 229-231; Seweryn Uruski, Rodzina. Herbarz szlachty polskiej, VIII, Warszawa 1911, s. 224; Kasper Nisiecki, Herbarz Polski, V, Lipsk 1840, s. 458; tamtéž, VIII, s. 599-601.

76 M. Baliński, Dawna Akademia Wileńska, s. 147-148; Konstancija Čepiené - Irena Petrauskiené (edd.), Vilniaus Akademijos Spaustuvès Leidiniai 1576-1805, Vilnius 1979, s. 95-96.

77 Owaszinowic ukončil studia v Praze v roce 1674 a na Akademii v Zamości se objevuje jako student v akademickém roce 1676/1677. Srov. AUK, f. Matriky, M 22, p. 146, 148; H. Gmiterek (ed.), Album studentów Akademii Zamojskiej, s. 271. 
příslušná označení během zápisu opomenuta, byl urozený původ identifikován za pomoci erbovních knih, ${ }^{78}$ protože jejich př́imí ne vždy prozrazovala urozený původ.

V matričním záznamu se samozřejmě nikdy neuvádělo, zda byl student měšt’anem. Jeho měšt’anský původ zpravidla vyplýval z označení místa bydliště zapsaného v matrikách, př́ipadně z př́ijmí, které většinou nemělo šlechtickou podobu, ačkoli to se týká pouze studentů pocházejících bezprostředně z Rzeczypospolité, protože pruská šlechta měla často př́imí považované v Polsku za měšt’anské. Šlechta z Rzeczypospolité, kromě všeobecně opovrhovaných výjimek (tzv. „,szlachta brukowa“ - od slova bruk, tedy dlažební kostka), nesídlila ve městech. Pokud se tedy v matrikách pražské univerzity objevil student z velkého polského nebo litevského města, takřka s jistotou se jednalo o měšt’ana. V př́ípadě pruských studentů nebylo možné řídit se tímto pravidlem, protože mnoho pruských šlechticů, pokud chtěli něco znamenat, naopak muselo sídlit ve městech. Proto se v matrikách objevují příslušníci šlechtických rodů usazených v urbánních centrech, jako byl Reszel, Braniewo, Dobre Miasto nebo Královec.

O venkovském původu studentů z Rzeczypospolité studujících v Praze nemá vůbec smysl uvažovat s ohledem na osobní poddanství tehdejších rolníků a mizivé reálné možnosti cestování za vzděláním do zahraničí kvůli nedostatku finančních prostředků. Selští synové se mohli účastnit výuky leda na farních školách, kde se učili zpěvu a elementárním dovednostem, ačkoli ani tyto školy nebyly všeobecně rozšířené. Objevovaly se ovšem př́ípady mimořádně nadaných selských synů, kteří studovali v církevních seminářích a získávali vedle skvělého vzdělání také dobrá místa $\mathrm{v}$ administrativě nebo akademické sféře; pocházeli hlavně z královských nebo biskupských panství. ${ }^{79}$ Pro mládež ze šlechtických statků bylo ještě složitější dostat se na domácí studia, a na zahraniční nemohli vůbec pomyslet. Dost sugestivním prríkladem je v tomto ohledu případ Kazimíra Dziurkiewicze, doktora filozofie a profesora matematiky v Krakově, který se v roce 1681 vydal na další studia do zahraničí. Stanisław Lanckoroński, majitel vsi, z níž profesor pocházel, jej nechal stíhat a uvěznil ho na svém panství jako zběhlého poddaného. ${ }^{80}$ Jestliže takový neprríjemný osud stihl známého a protežovaného profesora, pak běžný selský syn vůbec neměl možnost vydat se na studia do zahraničí.

U třinácti studentů se přes veškerou snahu nepodařilo zjistit sociální původ. Vyplývá to ze skutečnosti, že jejich příjmí byla bud' příliš zkomolena, nebo je písař vůbec neuvedl a bezvýsledná byla také konfrontace s erbovními knihami.

Šlechtický původ byl jednoznačně určen u čtyřiceti dvou studentů. Pocházeli převážně z méně známých rodů nižší a střední šlechty. Jen málokteří náleželi ke všeobecně známým a majetným rodům z Prus a Rzeczypospolité jako Szembek, Wiśniowiecki, Szaniawski, Cetner, Opaliński, Lanckoroński, Zakrzewski nebo Roth. Dodatečně se podařilo zjistit

78 A. Boniecki, Herbarz Polski; Jan Karol Dachnowski, Herbarz szlachty Prus Królewskich z XVII wieku, ed. Zdzisław Pentek, Kraków 1995; Kasper Niesiecki, Herbarz Polski, IV, V, VII-IX, Lipsk 1839-1842; Seweryn Uruski, Rodzina. Herbarz szlachty polskiej, I, IV, VI-VIII, XI, XIV, XV, Warszawa 1904, 1907, 1909-1911, 1914, 1917, 1931; Teodor ŻYCHLIŃSKI, Złota księga szlachty polskiej, I, V, Poznań 1879, 1883; Ludwik KorwIN, Ormiańskie rody szlacheckie, Kraków 1934.

79 Mirosława Chamcówna, Szkolnictwo wiejskie, in: Stefan Inglot (ed.), Historia chłopów polskich: opracowanie zbiorowe, I, Do upadku Rzeczpospolitej szlacheckiej, Warszawa 1970, s. 485.

80 R. T. Tomczak, Studenci ze Święciechowy, s. 120. 
Tabulka 3: Sociální původ studentů z Rzeczypospolité

\begin{tabular}{|l|l|l|l|l|}
\hline & celkem (100) & $\begin{array}{l}\text { korunní země } \\
\text { a Litva (77) }\end{array}$ & Prusy (23) & duchovenstvo (16) \\
\hline šlechta & $42 \%(42)$ & $48 \%(37)$ & $22 \%(5)$ & $56 \%(9)$ \\
\hline měšt’ané & $45 \%(45)$ & $38 \%(29)$ & $70 \%(16)$ & $38 \%(6)$ \\
\hline nezjiššeno & $13 \%(13)$ & $14 \%(11)$ & $9 \%(2)$ & $6 \%(1)$ \\
\hline
\end{tabular}

Zpracováno na základě matrik: AUK, f. Matriky, M 63, M 12, M 22; seznamů promovaných: AUK, f. ÚTKFU, I (1624-1690, 1650-1690), bez č. (1673-1690), II (1690-1697), III (1697-1701), IV (1701-1705), V (1705-1710), VI (1710-1716), VII (1716-1720), VIII (1720-1725), IX (1725-1729), X (1729-1733), XI (1733-1739), XII (1739-1805); edic: K. BERÁNEK (ed.), Magistri, baccalaueri; TÝŽ, Acta facultatis philosophicae.

dvacet pět erbů, které uvedení šlechtičtí studenti užívali při pečetění. Byly to erby: ${ }^{81} \mathrm{Grzy-}$ mała, Jelita, Łabędź, Szreniawa, Pobóg, Łodzia, Wieniawa, Przerowa, Kłosy, Ogończyk, Łada, Leliwa, Kościerza, Sas, Zadora, Prawdzic, Prus, Prus I, Topór, Junosza, Szembek, Korybut, Strzemie, Wyssogota a Nieczuja.

Měšt’anského původu bylo čtyřicet pět studentů. Pocházeli hlavně z velkých městských lokalit jako Gdaňsk, Varšava, Braniewo, Radom, Vilno nebo Zamość, ačkoli se objevuje i jeden případ masové akademické peregrinace $\mathrm{z}$ menšího města. Tuto výjimku představuje Święciechowa, ležící tehdy na jihozápadě Rzeczypospolité u hranic s habsburskou monarchií; odtud se do Prahy v letech 1643-1699 vydalo dokonce čtrnáct studentů. ${ }^{82} \mathrm{~V}$ tomto případě je možné hovořit o shora řízeném procesu iniciovaném jezuity z Hlohova, kteří studenty po ukončení pražských studií vysílali s rekatolizačními úkoly do Slezska. ${ }^{83}$

Jasně je tedy vidět, že mezi studenty pražské univerzity pocházejícími z Rzeczypospolité převažovali ti, kteří byli měšt’anského původu, i když je třeba zdůraznit, že rozdíl představuje pouze několik procent. Ve skutečnosti byl ale určitě o něco větší, protože značná část ze zmíněných $13 \%$ studentů neznámého sociálního původu byli pravděpodobně měštané, jinak by písaři zcela jistě neopomenuli zaznamenat jejich šlechtický původ. Potvrzuje se tak názor, že měšt’ané měli mnohem větší zájem na získání vyššího vzdělání, ačkoli představovali v Rzeczypospolité z politického hlediska marginalizovanou společenskou vrstvu. Ještě výraznější rozdíl se naskýtá v př́ípadě Prus, kde se $20 \%$ studentů honosilo šlechtickým původem a 70 \% studentů bylo původu měšt’anského. Je samozrrejmé, že takový stav věcí byl způsoben jinými důvody, než v případě korunních zemí, ale i tak je vidět, že právě pro měšt’any znamenalo vyšší vzdělání investici do zlepšení materiálního i společenského postavení.

81 V Polsku se v raném novověku používal omezený počet erbů, které měly vlastní názvy, na něž se běžně odkazovalo při uvedení jména rodu.

82 R. T. TомсZAK, Studenci ze Święciechowy, s. 120.

83 Hermann Hofmann, Die Jesuiten in Glogau, Breslau 1926, s. 19-20; Historia Collegii Glogoviensis Soc. Jesu, in: Festschrift zur Dreihundertjahrfeier 1626-1926 des Staatlichen Katholischen Gymnasiums in Glogau, Breslau 1926, s. 25-27; Julius BlaschKe, Geschichte der Stadt Glogau und des Glogauer Landes, Glogau 1913, s. 302, 325-326; Johann Schmid, Historiae Societatis Jesu Provinciae Bohemiae, IV/1, Pragae 1759, s. 785 . 
Je třeba se zastavit také u šestnácti studentů duchovního stavu, z nichž 56 \% představovali příslušníci šlechty, 38 \% měšt’ané a pouze v prŕípadě jednoho se nepodařilo jednoznačně stanovit sociální původ. Duchovenstvo nebylo sledováno jako samostatná sociální skupina, protože každý z reprezentantů kléru byl v prvé řadě šlechticem nebo měšt’anem a jeho př́slušnost $\mathrm{k}$ duchovnímu stavu nebyla dána jeho sociálním původem. Přesto ale písaři zapisující do matriky uváděli v osobních záznamech údaj o př́islušnosti ke kléru (prostřednictvím označení alumnus), o dosaženém svěcení (presbyter) nebo o funkci, kterou dotyčný zastával v církevní hierarchii jako canonicus, professus ex monasterio nebo hospitaliarius.

Závěry jsou tedy jednoznačné. Na pražské univerzitě převažovaly mezi studenty z Rzeczypospolité osoby měšt’anského původu, ačkoli o poměru mezi šlechtici a měšt'any co do množství rozhodla skupina čtrnácti studentů ze Święciechowé, kteří si Prahu jako místo dalšího vzdělávání zjevně vybrali s ohledem na její mimořádnou blízkost. K učinění takového závěru nás opravňuje skutečnost, že v jiných oblastech Evropy, zvláště západní, polská šlechta nad měšt'anstvem naopak převažovala. ${ }^{84}$ Praha je v tomto kontextu čímsi mimořádným. Vyplývá to do značné míry z toho, že zahraniční cesty prakticky všech studentů byly ovlivněny především jejich finančními možnostmi, proto se na zahraničních univerzitách, zvláště západoevropských, setkáváme s tím větším počtem šlechticů a s o to menším počtem měšt’anů, čím více byly vzdáleny od Rzeczypospolité. Naopak studenti měšt’anského původu z Prus počtem vždy převyšovali studenty šlechtického původu, i když právě v Praze byl poměr zhruba jen $3: 1$, zatímco na západoevropských univerzitách průměrně $10: 1 .{ }^{85}$ Nabízí se proto otázka, proč představitelé tak zámožných šlechtických rodů, jako byli Szembek nebo Wiśniowiecki, studovali právě v Praze. Odpověd’ je nejspíše jednoduchá. Pobyt v Praze považovali pouze za jednu ze zastávek na své cestě za vzděláním. Proto Wiśniowiecki po odjezdu z Prahy začal studovat ve Vídni ${ }^{86}$ a Szembek přijel do Čech, aby si doplnil své vzdělání získané v Římě. ${ }^{87}$

Praha tedy nebyla v Rzeczypospolité považována za atraktivní akademické centrum, zvláště v urozených vrstvách. Těžko mohla soupeřit s italskými univerzitami, módními nepřetržitě od 16. století, respektive později s univerzitami francouzskými. Sociální charakteristika studentů z Rzeczypospolité studujících v Praze se přitom značně odlišovala od obecných trendů ve vztahu k polským studentům na jiných univerzitách. Jako poměrně výstižné se proto jeví konstatování, že Praha a Čechy nebyly považovány za dostatečně ,zahraniční“.

\section{Průběh a typy studia}

Na pražské univerzitě měli studenti možnost studovat na čtyřech fakultách: filozofické, lékařské, právnické a teologické. Na každé z nich samozřejmě studium vypadalo jinak, zvláště vezmeme-li v úvahu, že fakulty filozofická a teologická byly v rukou jezuitů

84 M. Pawlak, Studia uniwersyteckie, Tab. 3an: Sociální původ studentů z Koruny a z Litvy zapsaných do alb západoevropských univerzit v letech 1501-1772.

85 Tamtéž, Tab. 1an: Sociální původ studentů z Královských Prus v letech 1501-1772.

86 Ilona Czamańska, Wiśniowieccy. Monografia rodu, Poznań 2007, s. 251.

87 Jan KoRYTKOwski, Arcybiskupi gnieźnieńscy: prymasowie i metropolici polscy od roku 1000 aż do roku 1821 czyli do połązenia arcybiskupstwa gnieźnieńskiego z biskupstwem poznańskim, IV, Poznań 1891, s. 546. 
(Klementinum), zatímco lékařská a právnická měly světský charakter (Karolinum). Filozofická fakulta se jakožto fakulta nižší navíc těšila mnohem větší oblibě. Teprve po jejím ukončení bylo možné studovat na vyšších fakultách, i když ani to nebylo vždy úplně dodržováno. ${ }^{88}$ Proto je třeba vyč́slit, kolik studentů z Rzeczypospolité studovalo na jednotlivých fakultách. Zároveň je nutné mít na paměti, že ti ambicióznější ze studentů mohli studovat na dvou, někdy dokonce na třech fakultách. Vyskytovaly se také př́pady, kdy polští studenti studující na některé $\mathrm{z}$ vyšších fakult získávali tituly na filozofické fakultě $\mathrm{v}$ zásadě extra ordinem, čili jinak než rádní studenti. Pokud se nedostavili na řádně vypsaný termín, docházeli pak na přednášky z filozofie jako studenti některé z vyšších fakult, stejně jako v př́ípadě, že již zastávali úřední funkci a cítili potřebu dodatečně získat vy̌šší vzdělání. ${ }^{89}$ Všechny typy př́ípadů budou popsány níže.

Největši zájem byl samozrejmě o filozofickou fakultu, nazývanou také fakultou svobodných umění. Ve sledované době na ní studovalo šedesát jedna studentů z Rzeczypospolité (z toho čtrnáct z Prus, dva z Litvy a jeden ze Žmudi), z nichž osm studovalo také na jiných fakultách (z toho dva $\mathrm{z}$ Prus) a šest ji ukončilo jako studenti extra ordinem (z toho jeden z Prus).

Studenti této fakulty se zpravidla snažili ukončit přinejmenším první dva ročníky (logika, fyzika), aby získali titul bakaláře. Někdy ale své studium skončili již v prvním ročníku, jako tomu bylo v prípadě několika studentů z Rzeczypospolité v letech 1642-1648. Dva z nich nepostoupili do vyššího ročníku nejspišs z důvodu neúspěchu během prosincových disputací a dva opustili Prahu z vlasteneckých důvodů, protože se vydali do války vedené Rzeczpospolitou v roce 1648 (contra Tartaros). Další dva byli odvoláni s ohledem na obležení Prahy švédskými vojsky (revocatus in patriam propter tumultum Suedicum)..$^{90}$ U zbývající dvojice studentů, z nichž jeden pocházel z Prus, nebyl udán důvod, proč studia ukončili již v prvním roce.

Zbytek studentů absolvoval první dvě třídy a získal tak titul bakaláře filozofie - celkem čtyřicet jedna osob (z toho devět z Prus, jeden z Litvy a jeden ze Žmudi), z nichž devatenáct svá studia v Praze $\mathrm{v}$ této fázi ukončilo (mezi nimi pět pocházelo $\mathrm{z}$ Prus a po jednom $\mathrm{z}$ Litvy a ze Žmudi). Pouze jeden student se rovnou zapsal na vyšší fakultu, zatímco ostatní pravděpodobně opustili město. Zbývajících dvacet dva bakalářů filozofie (z toho čtyři Prusové) začalo studovat třetí ročník (metafyzika), který úspěšně, čili s titulem mistra, ukončilo dvacet osob, z toho tři způsobem extra ordinem. Jeden Polák a jeden Prus až k úspěšné promoci nedospěli. Zbývajících deset (z toho tři z Prus a jeden z Litvy) získalo titul mistra, aniž by předtím v Praze úspěšně usilovali o titul bakaláře, který již mohli mít na základě studia jinde nebo jim byl udělen extra ordinem (to se týkalo tří studentů). Sečteme-li výše uvedená čísla, zjistíme, že z celkového počtu zbývají ještě dva studenti. Prvním z nich je Michal Korybut Wiśniowiecki, který studoval na filozofické a právnické fakultě, ale ani jednu z nich nedokončil, jak se o tom ještě dále zmíníme. Druhým je Ondřej Kazimír Kuropatnicki, který ukončil studia v Praze s titulem doktora filozofie. ${ }^{91}$

$\mathrm{V}$ pořadí druhou fakultou pražské univerzity těšící se značnému zájmu studentů byla fakulta právnická, i když ve srovnání se studenty z jiných zemí na ní studujících byla prítomnost

88 M. MošKoŘ, Skladba a uplatnění inteligence, s. 87.

89 K. BerÁneK (ed.), Magistri, baccalaueri, s. 5.

90 TÝž (ed.), Acta facultatis philosophicae, s. 181, 188, 192, 195, 197-199.

91 NK ČR, Th. 495. 
osob z Rzeczypospolité spíše skromná a př́ležitostná. ${ }^{92}$ Celkem zde studovalo třicet devět studentů z Rzeczypospolité ( $\mathrm{z}$ toho osm Prusů), z nichž třicet pět předtím nezískalo na pražském vysokém učení žádný titul. Jeden student z Prus získal již dříve v Praze titul bakaláře a zbývající tři (dva Poláci a jeden Prus) se kromě toho mohli vykázat i titulem mistra filozofie. Přítomnost studentů z Rzeczypospolité byla tedy rozhodně sporadická. Je ale třeba dodat, že právnická fakulta měla velmi slušnou úroveň, zvláště vezmeme-li v úvahu, že se její profesoři výborně orientovali v aktuálním evropském právním myšlení, protože jejich profese vyžadovala rozhled přesahující lokální český horizont. ${ }^{93}$ Poláky ovšem pražská právnická fakulta př́liš nepřitahovala - pro srovnání můžeme uvést, že ze Švábska pocházelo v letech 1638-1704 celkem čtyřicet osm jejích studentů a dokonce i ze vzdálené Itálie prrijelo v téže době do Prahy devatenáct studenti̊. ${ }^{94}$

S ohledem na to, že právnická fakulta náležela mezi tři vyšší fakulty, je třeba předpokládat také úměrně vy̌šś věk jejích studentů, který se konkrétně pohyboval v rozmezí mezi dvacátým a třicátým rokem. Navíc měli disponovat titulem mistra filozofie, což ale nebylo vždy striktně vyžadováno a v praxi byli zapisováni i studenti s podmínkou, že si během prvního roku studií vzdělání doplní, například způsobem extra ordinem. Kdyby tak neučinili, neměli by šanci pomýšlet na titul licenciáta nebo doktora práv, pro něž byl titul mistra filozofie nezbytnou podmínkou. Aby studenti na této fakultě mohli získat akademický titul, museli navíc složit dvě zkoušky a úspěšně absolvovat disputaci, která předcházela promoci. ${ }^{95}$ Proto př́liš neudiví, že žádný ze studentů z Rzeczypospolité neukončil studium na právnické fakultě získáním titulu licenciáta nebo doktora práv. Většina z nich ani nesplnila základní podmínky, totiž předchozí promoci na mistra filozofie.

Další fakultou na pražském vysokém učení byla fakulta lékařská. Na ní studovalo šest studentů z Rzeczypospolité, z nichž dva pocházeli z Prus. ${ }^{96}$ Vzhledem k charakteru studia se nejednalo o př́liš vyhledávanou fakultu. Ročně se na ni zapisovalo kolem šesti studentů, převážně měštanského původu. ${ }^{97}$ Jen malá část $\mathrm{z}$ celkového počtu (asi $28 \%$ ) navíc podstupovala závěrečné zkoušky, aby získala titul doktora. Většina posluchačů po půlroční nebo roční účasti na přednáškách odcházela na jinou univerzitu nebo rovnou začínala $\mathrm{s}$ lékařskou praxí. Tendenci $\mathrm{k}$ tomu měli zejména zahraniční studenti. I na lékařské fakultě bylo podmínkou pro príjetí získání akademického titulu mistra na nižší fakultě, ačkoli ve skutečnosti tento požadavek splňovalo jen málo studentů. Lze to sledovat i na príkladu studentů z Rzeczypospolité, z nichž jeden se mohl vykázat (v Praze získaným) titulem bakaláře filozofie a pouze jediný splňoval základní podmínku, a to díky získání titulu mistra (ovšem extra ordinem).

Ze studentů pocházejících z Rzeczypospolité se na medicínu zapsali čtyři, z toho dva pouze v prvním roce. Další byl zapsán jako student farmacie. Poslední je v matrice zaznamenán jako student chirurgie, přesněji „,chyrurgi ophtalmici et lithotomi“. Jednalo se

92 K. KUČERA - M. TruC, Zahraniční studenti, s. 70-71.

93 Jaroslav PÁneK, Praskie środowisko akademickie w XVI-XVIII stuleciu, in: Henryk Gmiterek (ed.), W kręgu akademickiego Zamośćia. Materiały z międzynarodowej konferencji na temat: Akademia Zamojska na tle praktyki edukacyjnej w Europie Środkowo-Wschodniej (koniec XVI-koniec XVIII wieku) Lublin - Zamość, 11-13 maja 1995, Lublin 1996, s. 36.

94 K. KuČERA - M. TRUC, Zahranični studenti, s. 72.

95 Ivana ČonneJová (ed.), Dějiny Univerzity Karlovy, II, 1622-1802, Praha 1996, s. 148-149.

96 AUK, f. Matriky, M 63, p. 30-31, 56, 70, 76, 100.

97 K. KuČERA - M. Truc, Matricula facultatis medicae, s. XLIII-LIII. 
o studenta, který pocházel z Lešna, na lékařskou fakultu se zapsal v roce 1714 a předtím dlouho sloužil ve válce. ${ }^{98}$ Muselo se tedy jednat o domácí válku mezi sandoměřskou a varšavskou konfederací (1704-1706), respektive obecně Velkou severní válku (1700-1721). Takoví chirurgové náleželi mezi speciální chirurgy, kteří putovali od města k městu a nejčastěji své operace prováděli na městských tržištích, kde léčili oční choroby (např. zákal čočky) nebo odstraňovali močové kameny. ${ }^{99}$ Zmínit musíme také jednoho ze studentů, který sice nebyl Polákem, ale s Rzeczpospolitou byl do značné míry svázán. Jde o Karla Heinricha Sengera, původem z Drážd'an, který se na lékařskou fakultu zapsal v roce 1740 po předchozích studiích na domácí půdě a který byl synem lékaře polského krále z dynastie Wettinů, $v$ matrice ale není přesně uvedeno, o kterého $\mathrm{z}$ obou králů se jedná. ${ }^{100}$

Poslední z fakult byla fakulta teologická, pro niž ale nejsou dochovány matriky, na jejichž základě bychom mohli zjistit, kolik studentů z Rzeczypospolité zde studovalo. Pouze za pomoci matriky fakulty svobodných umění, do níž bylo někdy zapisováno, na jaké další fakultě student ještě studuje, můžeme zjistit, že tři tam zapsaní polští studenti studovali také na teologické fakultě. ${ }^{101} \mathrm{Z}$ matriky filozofické fakulty vyplývá, že titul bakaláře získal jeden student z Polska, který se předtím stal mistrem filozofie (extra ordinem). Zbývající dva byli uvedeni jako posluchači teologie $\mathrm{v}$ souvislosti s jejich promocí na bakaláre filosofie (extra ordinem), přičemž jeden z nich později opakovaně, když byl promován na mistra (rovněž extra ordinem).

\section{Ubytování v konviktu sv. Bartoloměje a v semináři sv. Václava}

Další nezbytný prvek studia, bez jehož zajištění by účast na výuce v Praze nebyla možná, představovalo obstarání odpovídajícího dočasného ubytování. Otázka důkladného poznání míst, kde studenti z Rzeczypospolité přebývali, je velmi složitá vzhledem k nedostatku pramenů i př́slušné literatury. Pouze v př́ípadě $15 \%$ studujících z Rzeczypospolité můžeme tuto problematiku podrobněji sledovat, protože zápisy $\mathrm{v}$ matrikách $\mathrm{v}$ jejich př́padě uvádějí dodatečnou informaci o ubytování v konviktu sv. Bartoloměje nebo v semináři sv. Václava, což byly fakticky studentské internáty pod patronátem jezuitů. Takový záznam ve formě „ex seminario S. Wenceslai nebo ex Convictu S. Bartholomei“ jednoznačně odkazoval na místo pobytu daného studenta. Také ostatní studenti samozřejmě museli během svého pobytu v Praze někde bydlet. $V$ závislosti na svých finančních možnostech měli na výběr mezi univerzitními kolejemi, akademickými či privátními internáty nebo pronájmem bydlení v soukromí. Jen těžko si lze představit, že by kníže Wiśniowiecki, Krzysztof Szembek nebo jiní představitelé význačných šlechtických rodů bydleli na druhořadých místech, když si mohli pronajmout prostor odpovídající jejich společenskému postavení. Tato otázka si však ještě vyžádá podrobnější pramenný výzkum.

Nezbývá tedy než se zabývat jedinými ověřenými informacemi, které jsou k dispozici,

a to ubytováním $\mathrm{v}$ konviktu a $\mathrm{v}$ semináŕi. Konvikty a semináře byly ve sledované době svého druhu školami s internátem nebo školními internáty. Seminář byl ve starších dobách

98 AUK, f. Matriky, M 63, p. 258.

${ }^{99}$ K. KUČERA - M. Truc, Matricula facultatis medicae, s. LXXIV.

100 AUK, f. Matriky, M 63, p. 92.

101 AUK, f. Matriky, M 22, p. 146, 148, 274-276, 333-336. 
určen pro mladé duchovní a především pro chudší studenty, kteří byli během svých studií odkázáni na hmotnou pomoc. Označení „konvikt“ se oproti tomu vztahuje k instituci, jejímž dodatečným úkolem bylo zajištění výchovy mladíků (například šlechtického původu), kteří hmotnou pomoc nepotřebovali. Toto rozdělení se v rámci jezuitského řádu objevovalo často a víceméně odpovídalo rozdělení na koleje a bursy. ${ }^{102}$

Proto byla užívána speciální terminologie, aby bylo zřejmé, co ubytovaný student studoval nebo z jaké fundace čerpal stipendium. Termíny alumnus nebo alumni ecclesiastici byli označováni studenti teologie. Toto pojmenování nacházíme u šesti studentů z Rzeczypospolité. ${ }^{103}$ Convictores nebo alumni saeculares se pak užívalo pro studenty z př́slušného řádu, termín alumni caesarei byl zaveden pro stipendisty fundace Ferdinanda II. a alumni pontifici pro studenty z fundace Řehoře XIII. ${ }^{104}$ Uvedená označení nebyla přiřazena k žádnému z polských studentů.

Semináŕ sv. Václava generoval po celou dobu své existence větší počet studentů než konvikt. Vyplývalo to ze skutečnosti, že vlastní náklady studentů byly v semináři menší než v konviktu, takže semináŕ byl pro chudší studenty snáze dostupný. Většina z nich pocházela samožrejmě z Čech. Zahraniční studenti nepředstavovali více než $10 \%$ z celkového počtu ubytovaných, proto není překvapivý ani malý počet studentů z Rzeczypospolité mezi nimi. $\mathrm{K}$ cizincům i domácím se přistupovalo stejně, a to i v tom ohledu, že všichni museli ovládat češtinu.

Studenti šlechtického původu představovali v konviktu $16,5 \%$, zatímco v semináři podstatně méně, ačkoli prameny neumožňují přsesnější stanovení jejich počtu. ${ }^{105}$ Ze studentů z Rzeczypospolité ubytovaných $\mathrm{v}$ semináŕi byl šlechtického původu jeden, zatímco z jedenácti ubytovaných $\mathrm{v}$ konviktu se jednalo o šest mladých šlechticů, celkem tedy o polovinu polských studentů ubytovaných na obou místech.

Aby se student dostal do konviktu nebo semináŕe, musel bud' zaplatit př́slušnou sumu, nebo být stipendistou některé z četných fundací. Celkem bylo v letech 1583-1773 takových fundací šedesát šest. ${ }^{106}$ Není ovšem známo, zda byl mezi polskými studenty stipendista některé z nich. Lze se domnívat, že spíše ano, protože řada z nich měla původ v odlehlých provinciích Rzeczypospolité, což znamenalo větší náklady na samotnou cestu do Prahy a menší naději na rychlé nalezení ubytování. Tř̆i studenti pocházeli z Královských Prus, dva z Velkoknížectví litevského, dva z Mazovska, jeden z Rusi ${ }^{107}$ a jeden z Podlesí. Jednalo se tedy z větší části o studenty $z$ oblastí od Prahy nejvzdálenějších.

Obraz ubytování studentů z Rzeczypospolité a jejich života mimo akademické prostředí je neúplný a bude vyžadovat ještě rozsáhlý pramenný výzkum, který může přinést množství zajímavých informací z oblasti dějin každodennosti. Je třeba zdůraznit, že symboly studentského života oné doby byly pero a kord, vedle vzdělání tedy jeho nedílnou součást tvořily různé typy rvaček a činů, jež svou povahou na první pohled nenáležely ke společenskému

102 Eva DoležAlovÁ, Seminář svatého Václava a konvikt svatého Bartoloměje v Praze na Starém Městě, Pražský sborník historický 31, Praha 2000, s. 186.

103 K. Beránek (ed.), Acta facultatis philosophicae, s. 37; AUK, f. Matriky, M 22, p. 47-48, 50-51, 58-59, 134-135, 179-180.

104 E. Doležalová, Seminář svatého Václava, s. 216-217.

105 Tamtéž, s. 222-223, 190.

106 E. DoležAlová, Nadace pro jezuitský seminář a konvikt v Praze jako specifický prvek barokní kultury, in: Olga Fejtová (ed.), Barokní Praha - barokní Čechie 1620-1740, Praha 2004, s. 583.

107 Srov. pozn. 71. 
postavení studenta. Jistě i Poláci měli možnost zapojit se do některé z jedenácti velkých, několikadenních studentských rozmíšek v letech 1650-1710, zvláště vezmeme-li v úvahu, že pouličních bouří v březnu 1655 se účastnilo na pět set studentů pražského vysokého učení. ${ }^{108} \mathrm{~V}$ Praze tehdy pobývalo asi pět studentů z Rzeczypospolité. Není proto divné, že se vedení konviktu sv. Bartoloměje i semináře sv. Václava snažilo zcela vyplnit čas svých svěřenců. Běžní studenti měli oproti nim mnohem více času, který mohli věnovat záležitostem s univerzitním studiem souvisejícím jen velmi vzdáleně.

\section{Ukončení studia}

Stejně jako na ostatních univerzitách, také na té pražské bylo přelomovým bodem v životě každého studenta ukončení studia a získání akademického gradu. Než se ale čerstvě promovaní bakaláři či mistři mohli z uděleného titulu začít těšit, museli pro jeho získání splnit několik podmínek. Především bylo nutné zhostit se slavnostní disputace, která v zásadě nebyla běžnou zkouškou, ale náročným testem erudice studenta. Slušelo se tedy dobře se na ni připravit, mj. i kvůli tomu, že se jí účastnili také další mistř̌i, doktoři a profesoři. ${ }^{109}$ Celý průběh disputací jako akademického rituálu byl podrobně předem popsán ve zvláštním, slavnostním úředním tisku vyvěšovaném na bránu koleje. Toto oznámení zahrnovalo také informace pro kandidáty přistupující k závěrečným zkouškám ohledně toho kdy a v které učebně se bude př́slušná slavnostní disputace konat. ${ }^{110}$

Poté, co se studenti dostavili na určené místo, čekali až do okamžiku, kdy jejich jméno prečetl univerzitní notář, který zároveň uvedl jejich věk, místo původu a údaje o studiu včetně předchozích zkoušek a splnění jiných akademických povinností. Kromě toho se zeptal každého ze studentů na stav jeho poznámek, zda se chce podvolit hodnocení examinátorů, zda nemá poskvrněnou pověst, která by byla újmou pro akademické důstojenství, a nakonec, zda je zapsán v univerzitní matrice. Poté profesoři určili, jak přesně se bude konat závěrečná zkouška a byl pořízen abecední seznam kandidátů. Ten začínal studenty usilujícími o nižší akademické grady, po nich následovali ti, kdo chtěli získat vyšší titul, a nakonec studující extra ordinem. Studenti byli dodatečně poučeni, aby si na zkoušku neopomněli přinést své poznámky z přednášek, aby examinátoři mohli ohodnotit jejich celkovou píli během studia. ${ }^{111}$

Zkoušky probíhaly od deváté do desáté hodiny dopoledne a mezi třetí a pátou hodinou odpoledne. Uchazeče o titul bakaláře zkoušeli čtyři profesoři půl hodiny a znalosti budoucích mistrů byly podrobovány zkoušce dvakrát tak dlouho. Po skončení disputace vypracoval každý z profesorů nezávisle na ostatních seznam absolventů, seřazených za sebou podle úspěšnosti př̌ skládání zkoušky, a předal jej děkanovi. Na jeho rozhodnutí záviselo stanovení definitivního pořadí, v němž byli absolventi promováni a zapsáni do matrik. ${ }^{112}$

108 Ivana RaKovÁ, Boure studentů pražské univerzity ve druhé polovině 17. století, AUC-HUCP 21/2, 1981, s. $7-12$.

109 Ivana Č́nNejovÁ, Pražské univerzitni slavnosti v 17. století, Documenta Pragensia 12, Praha 1995, s. 137-138.

110 K. BERÁNEK (ed.), Magistri, baccalaueri, s. 5.

${ }^{111}$ De petitione graduum et conditionibus admittendorum, in: Karel Beránek (ed.), Statuta university u sv. Klimenta v Praze, AUC-HUCP 12/1-2, Praha 1972, s. 219-220.

112 De decanis theologicae et philosophicae facultatis, in: Karel Beránek (ed.), Statuta university, s. 214-218. 
Po zkouškách určil kancléř datum slavnostní promoce, která byla ohlašována formou úředního oznámení připevňovaného na brány kolejí a jiná místa ve městě. Studenti měli dodatečně možnost pozvat na promoci osoby, jimž byli povinováni vděčností. Nejčastěji byli prostřednictvím zrrízence zváni kancléř, rektor, profesoři, doktoři a probošti. V roce 1649 byl dokonce pozván švédský generál Wittenberg - týž, který později stanul v čele švédské armády vtrhnuvší do Rzeczypospolité na počátku tzv. švédské potopy, prrijímal kapitulaci Velkopolska u města Ujście (1655), dobyl Krakov, velel obraně okupované Varšavy a nakonec zemřel v polském zajetí v pevnosti Zamość. ${ }^{113}$

Kromě úspěšného složení závěrečných zkoušek musel každý ze studentů splnit ještě několik podmínek, aby mohl být připuštěn k promoci a získat akademický titul. Především byl povinen složit vyznání víry podle ustanovení tridentského koncilu, spojené s př́ísahou na neposkvrněné početí Panny Marie. ${ }^{114}$ Je třeba dodat, že akademické grady nebyly udělovány ,z moci úřední“. Student musel osobně požádat, aby mu byl titul přiznán, at’ už se jednalo o hodnost bakaláře, mistra či doktora.

Už jsme se zmínili o akademických gradech, které získalo čtyřicet devět studentů z Rzeczypospolité. Ti měli možnost účastnit se všech výše uvedených slavnostních ceremoniálů spojených s koncem studia, přičemž dvacet tři z nich se díky získání dvou titulů (bakaláře i mistra) účastnilo těchto aktů opakovaně. Je třeba připomenout dva studenty ze Święciechowy, Martina Wirdta a Řehoře Hoffmana, pro něž byly ceremonie spojené s absolutoriem ještě slavnostnější, protože jejich filozofické disputace vedené s cílem získání titulu bakaláře probíhaly během závěrečných zkoušek veřejně, a tím se jim v celkovém kontextu dostalo zvláštního uznání. V př́ípadě prvního z nich se tak stalo v roce 1641 , v př́ípadě druhého $v$ roce 1643.115

Jestliže je řeč o disputacích, je nutné přiblížit také jejich témata. Na konci každého záznamu v akademické matrice týkajícího se nově promovaných absolventů, at' už bakalářu či mistrů, byla zaznamenána problematika, na jejímž základě studenti získávali své tituly (problema resulta). Pro každý ročník promovendů se pravidelně počítalo se dvěma problémy z různých vědních oblastí. V letech 1641-1727 měli budoucí bakaláři filozofie pocházející z Rzeczypospolité možnost projevit se v šedesáti devíti různých tématech z deseti oborů (filozofie, matematika, optika, astronomie, astronomická optika, metafyzika, fyzika, statika, astrologie a geometrie). Mistři filozofie z let 1641-1728 pak mohli diskutovat o padesáti různých tématech ze sedmi vědních disciplín (filozofie, etika, matematika, fyzika, politika, politická etika a meteorologie). Na podrobné představení témat řešených studenty tu nemáme dostatek prostoru, představme si tedy alespoň povšechně jejich charakter.

Všeobecně témata samozřejmě odrážela celkový program studií, vykazovala tedy silné známky sofismat. Tak např́klad v roce 1644 mohli studenti při snaze získat mistrovský titul diskutovat o možnosti omládnutí starších lidí a prodloužení jejich života až o tisíc let (Possitne homo senex naturaliter reiuvenescere et vitam humanam his etiamnum temporibus prorogare ad sexcentos, millenos pluresve annos?) $)^{116}$ nebo v roce $1675 \mathrm{v}$ souvislosti se získáním titulu bakaláře promluvit o příznivých účincích tabáku na lidské zdraví ( $A n$

\footnotetext{
113 Kazimierz LePszy, Wittenberg Arvid, in: K. Lepszy (ed.), Słownik biograficzny historii powszechnej do XVII stulecia, Warszawa 1968, s. 458.

114 I. Čornejová, Pražské univerzitní slavnosti, s. 138.

115 K. BerÁneK (ed.), Acta facultatis philosophicae, s. 46-48, 58-59; tÝž (ed.), Magistri, baccalaueri, s. $106,268$. 116 TÝž (ed.), Acta facultatis philosophicae, s. 76.
} 
usus Tabacae conducat ad Vitam diuturniorem?). ${ }^{117}$ Může nás do jisté míry překvapit, že $\mathrm{v}$ roce 1728 se objevila také témata povýtce rétorické povahy a navíc z oblasti vojenství (An Equitatus praestet Peditatui ad obtinendam Victoriam?). ${ }^{118}$ Setkáváme se ale samozřejmě i s celkem praktickou problematikou a jejím odpovídajícím uchopením, at již máme na mysli pozorování komet z let 1664 a 1680, zkoumání děl Avicenny či Archimeda, př́ípadně různé problémy z oblasti matematiky a aritmetiky. Obecně dominovala témata, která ideálně odpovídala scholastickému pojetí spekulativní filozofie.

Dalším důležitým prvkem, který souvisel s promocemi na filozofické fakultě, byly slavnostní grafické akademické teze. ${ }^{119}$ Jedná se o velkoformátovou, jednostránkovou grafiku, tištěnou většinou na papíru (někdy také na hedvábí), která na filozofické fakultě pražské univerzity v letech 1637-1764 sloužila jako okázalá památka a svědectví o veřejné disputaci filozofických tezí podmiňující získání akademického gradu.

Mezi 526 grafickými tezemi uloženými v Národní knihovně ČR se dochovaly čtyři, jejichž objednavateli byli Poláci. Jsou mimořádnou uměleckou památkou, protože byly zhotoveny s maximální pečlivostí, zpravidla v zahraničních tiskárnách a podle předloh čelných evropských výtvarných umělců. Po grafické stránce se teze dělily na dvě části. Horní, podstatně větší část, zahrnovala alegorické vyobrazení katolických světců, biblických dějů, vedut měst, portréty vládců a členů panujících rodin nebo vlivných politiků. Dolní část oproti tomu zachycovala ve slavnostní podobě informaci o objednavateli grafické teze, studentovi, který měl dané téma obhajovat, a po stranách byl obvykle uveden výčet otázek, o nichž měl student diskutovat. ${ }^{120}$

První z uvedených grafických tezí byla objednána chelmským biskupem a pozdějším polským primasem Andrzejem Olszowským u př́ležitosti promoce Tomáše Grądzkého na mistra filozofie v roce 1661. Jeho teze (rozměry: $106,4 \mathrm{~cm} \times 74,3 \mathrm{~cm}, 109,8 \mathrm{~cm} \times 80,5 \mathrm{~cm}$ ) představuje alegorickou kompozici s Apolónem a Neptunem. Autorem této mědirytiny byl Friedrich Angellus. ${ }^{121}$

Chronologicky druhá a zároveň nejzajímavější byla teze dedikována králi Janu III. Sobieskému a jeho synu Jakubovi. Byla zhotovena v souvislosti s promocí Ondřeje Kazimíra Václava Kuropatnického na mistra filozofie v roce 1682. Jedná se rovněž o mědirytinu (rozměry: $95 \mathrm{~cm} \times 146 \mathrm{~cm}, 103 \mathrm{~cm} \times 148,5 \mathrm{~cm}$ ), jejíž autor Bartoloměj Kilian mladší ji vytvořil podle předlohy slezského umělce Martina Antonína Lublińského. Kuropatnického teze je v rámci sbírek pražské Národní knihovny jednou z nejokázalejších, protože se týká hrdinských činů polského krále a obsahuje proto také množství alegorických odkazů. ${ }^{122}$

Třetí z ,polských“ tezí objednal Kryštof Antonín Szembek u př́ležitosti své promoce na mistra filozofie v roce 1699 . Jeho grafická teze (rozměry: $76,6 \mathrm{~cm} \times 54,2 \mathrm{~cm}, 79,3 \mathrm{~cm} \times 55$

\footnotetext{
117 AUK, f. Matriky, M 22, p. 152.

118 AUK, f. ÚT KFU, IX (1725-1729), p. 67.

119 Podrobněji o grafických akademických tezích a o související literatuře pojednává autor v připravovaném článku týkajícím se grafické teze Ondřeje Kazimíra Kuropatnického: R. T. TомсzAK, Graficzna teza akademicka Andrzeja Kuropatnickiego (v tisku).

120 Anna Fechtnerová, Katalog grafických listů univerzitnich tezi uložených ve Státní knichovně ČSR v Praze, I, Praha 1984, s. II-III.

121 NK ČR, Th. 346.

122 NK ČR, Th. 495.
} 
cm) představuje Neposkvrněné početí Panny Marie. Jedná se o sítotisk, jehož autorem byl Jan van der Bruggen. ${ }^{123}$

Poslední z tezí objednal Konstantin Kazimír Brzostowski, biskup vilenský, u prŕíležitosti promoce Marciana Junosze Szianiawského na mistra filozofie v roce 1709. Představuje zásnuby Panny Marie (rozměry: $158,5 \mathrm{~cm} \times 92 \mathrm{~cm}, 161,5 \mathrm{~cm} \times 94 \mathrm{~cm}$ ). Autorem tohoto sítotisku byl Alexandr Marchesinus. ${ }^{124}$

Obraz zakončení studií by nebyl úplný, kdybychom nepopsali související slavnostní události. Začínaly v den promoce brzy ráno, již kolem sedmé hodiny. Kandidáty na promoci provázeli trubači a po mši v kostele sv. Salvátora je na samotné místo slavnostního aktu uvedl pedel s žezlem př́slušné fakulty. Když se studenti dostavili na místo promoce, promotor každému z nich udělil jejich nový akademický titul, zatímco promovendi měli odpovědět na sérii formálních otázek a přiložit dva prsty na rektorské žezlo. Poté nově promovaní akademici oficiálně prezentovali témata svých disputací a promotor některým z nich dodatečně poděkoval. Následovaly proslovy promovendů, v nichž děkovali Bohu, svatému Ignáci, svatému Františku Xaverskému, panovníkovi, akademickému magistrátu, promotorovi a jiným osobám přítomným promoci. ${ }^{125}$ Jednotlivé děkovné řeči od sebe oddělovaly fanfáry. Proslovy bývalých studentů slavnost končila a všichni se za zvuků trub navrátili do kolejí, ${ }^{126}$ kde jistě pokračovala neformální část oslav nově získaných akademických gradů.

\section{Pražská studia Michala Korybuta Wiśniowieckého}

Jedním z nejznámějších polských studentů, kteří měli příležitost studovat na pražské univerzitě, byl nepochybně Michal Korybut Wiśniowiecki (1640-1673), posléze šestý z volených králů Rzeczypospolité. Je všeobecně známo, že Michal Korybut studoval na pražské univerzitě v letech 1656-1660, dosud ale nebyl proveden důkladný pramenný výzkum týkající se této životní etapy budoucího monarchy. V polské historiografii vznikly dvě práce, které se studiem knížete částečně zabývají, jsou ale omezeny hlavně na informace získané z polských pramenů, zejména z korespondence, aniž by alespoň částečně braly v potaz české prameny a literaturu. Jedná se o práce Adama Przybośe a Ilony Czamańské. ${ }^{127}$ Česká historiografie se zase vedle povšechné informace o studiích Wiśniowieckého soustřed'uje hlavně na pověstný dar, který pražskému vysokému učení věnoval, a v zásadě při té prríležitosti polského krále jen zmiňuje, ${ }^{128}$ prričemž se odvolává na prameny české provenience. Potřeba kompletace výsledků české a polské historiografie je tedy v př́padě pražského studia Michala Korybuta Wiśniowieckého zcela zřejmá.

123 NK ČR, Th. 027.

124 NK ČR, Th. 496.

125 K. BERÁneK (ed.), Magistri, baccalaueri, s. 6-7.

126 I. ČornejovÁ, Pražské univerzitní slavnosti, s. 138.

127 A. Przyboś, Michał Korybut Wiśniowiecki, s. 25-27; I. Czamańska, Wiśniowieccy, s. 249-251. Samostatný článek pojednávající šířeji o výchově a vzdělání budoucího polského krále byl vydán nedávno: R. T. ToMCZAK, Wychowanie i wykształcenie króla Michała Korybuta Wiśniowieckiego (1640-1660), RH 39, 2015, s. 30-58.

${ }^{128} \mathrm{Z}$ nejnovějších prací zmiňujících se o studiu Michala Wiśniowieckého v Praze: Vladimír ZÁvodsKÝ, Rytina obrazu svaté Kateřiny z Pražského Karolina, AUC-HUCP 33-34/1-2, 1993-1994, Praha 2007, s. 115-121; Lenka Stolárová - Vít Vlnas, Karel Škréta 1610-1674. Doba a dílo, Praha 2010, s. 230-233. 
Ve věku jedenácti let ztratil mladý aristokrat otce, v Polsku i na Ukrajině proslulého knížete a vojevodu ruského Jaremu Wiśniowieckého, erbu Korybut. Ačkoli jej jeho manželka Griselda z Zamojských přežila, byla natolik zaneprázdněna majetkovými záležitostmi, že se nemohla věnovat výchově nezletilého syna. Kníže potřeboval mocného protektora, který by zajistil jeho vzdělání a zaštítil budoucí politickou kariéru. Stal se jím jeho strýc z matčiny strany, Jan Sobiepan Zamojský, vlastník ohromného majetku a mimořádně schopný vojevůdce. $\mathrm{V}$ pozdější době se $\mathrm{k}$ okruhu protektorů Michala Wiśniowieckého prridala také královna Ludvika Marie. ${ }^{129}$ Je naprosto zřejmé, že již na počátku své životní dráhy (ač de facto jako vyhnanec z východních oblastí Rzeczypospolité) měl mladý aristokrat zajištěny dokonalé konexe a podmínky pro započetí důkladného studia i pro budoucí politickou kariéru.

Zpočátku byl mladý kníže svěřen do péče vratislavského a plockého biskupa, kralevice Karla Ferdinanda Vasy. ${ }^{130}$ Pobýval tehdy v biskupské rezidenci v Broku pod dohledem knížete Jana Chrysostoma Fabricia, který v dopisech informoval Jana Zamojského o zdraví a pokrocích jeho synovce. ${ }^{131}$ Nejspíše po smrti biskupa Vasy v květnu 1655 byl kníže odeslán na královský dvưr. Po peripetiích spojených se „švédskou potopou“ a přesídlením královského dvora do Slezska se Michal Wiśniowiecki nakonec ocitl v Nise, kde studoval v jezuitské koleji přinejmenším do března 1656.132

Posléze se díky podpoře strýce a královské protektorky odebral do Prahy, kde zahájil čtyřleté studium na pražské univerzitě. Během pobytu v Čechách o něj pečoval Felician Wąsowicz, erbu Łabędź, který Jana Zamojského informoval o synovcově studiu. V jediném zachovaném dopise z konce listopadu 1656 podával knížecí preceptor relaci o společném pobytu v Drážd’anech, která si zaslouží obsáhlejší citát: „Pod czas teraźnieyszey iesieny, gdy Książę Jegomość wakowat od nauk, wyjeżdżat z Pragi do Drezdy, Ksiązęcia saskiego rezydencyey, iuż byt elektor dwiema dniami przed przyjazdem Księcia Jegomości umarl. Po śmierci elektora przez trzy dni nie puszczano do miasta ani z miasta. Dostało się czwartego dnia Księciu Jegomości, wszelakie widzieć dostatki w Kunstkammer, wielki porzadek $w$ woyennych rzeczach, $w$ koniach, $w$ myślistwie, y różnych bestyach, czym się wielce Ksiaże Jegomość ucieszyt. Powróciwszy szczęśliwie do Pragi, z uniżonemi nami, odzywam się wielce Miłościwy Panie."133 (Během tohoto podzimního času, kdy se kníže nezabýval studiem, odjel z Prahy do Drážd’an, saské knížecí rezidence, ale kurfiřt dva dny před př́ijezdem Jeho Knížecí Milosti zemřel. Po kurfiřtově smrti se nevpouštělo do města ani z města. Čtvrtého dne se Jeho Knížecí Milosti podařilo prohlédnout si drahocennosti v kunstkomoře, pořádek panující ve vojenských záležitostech, chovu koní, skotu i myslivosti, což Jeho Knížecí Milost velice potěšilo. Po št’astném návratu do Prahy Vám, vysoce milostivý pane, poníženě píšu.)

Na spodní části listu se nachází vlastnoruční poznámka F. Wąsowicze, který informuje, že dopisy Jana Zamojského knížeti dosud nebyly doručeny a z Nisy se dozvěděl , „̇e je trębacz iaky miat pogubič" (že je měl ztratit jakýsi trubač). Výjezd do Drážd’an se musel

129 A. PrzyBoś, Michat Korybut Wiśniowiecki, s. 26.

130 Wespazjan Kосноwsкi, Roczników polskich klimakter IV obejmujący dzieje Polski pod panowaniem króla Michała, ed. Jan Nepomucen BoBrowicz, Leipzig 1853, s. 326-327.

${ }^{131}$ AGAD AZ 1062, s. 1.

132 I. CZAMAŃsKa, Wiśniowieccy, s. 251.

133 AGAD AZ 1155, s. 1. 
uskutečnit v prvním říjnovém týdnu, protože saský kurfiřt Jan Jiří I. z rodu Wettinů zemřel 8. ř́ijna 1656. Podle datace listu je možné soudit, že kníže pobyl v Drážd’anech necelé dva měsíce. Je jasně vidět, že exponáty v drážd’anském kabinetě kuriozit se pro šestnáctiletého mladíka ukázaly jako mnohem přitažlivější než studium na pražské univerzitě, protože akademický rok na filozofické fakultě, kde kníže studoval, začínal počátkem listopadu a záznamy do matriky byly pořizovány počátkem prosince. ${ }^{134}$ Snad je to důvodem, proč se kvůli zpoždění už nemohl do matriky oficiálně zapsat a proč také jeho jméno schází i v dalších letech. Je také třeba zmínit, že dopisy Zamojského, které se neštastnou náhodou nedostaly z Nisy adresátům, mohly obsahovat podrobné pokyny a rady, jak se má postupovat během prvních měsíců pobytu knížete v Praze.

Polské prameny nám bohužel neposkytují př́liš mnoho informací o studiu knížete Michala Wiśniowieckého v Praze. Kromě uvedeného listu se dochoval pouze jediný další, který může tuto otázku poněkud osvětlit. Dopis psaný Janu Zamojskému Ludovikou Marií se týká poslední etapy pražského pobytu knížete, a tedy jeho odvolání z Prahy. Je datován 10. února 1660 a představuje odpověd' královny na list Zamojského, v němž se dotazoval na další kroky, které je nutné učinit ve věci výchovy knížete Michala. ${ }^{135}$ Ludvika Marie v dopise sděluje, že dosud nepomýšlela na změnu prostředí ani snížení nákladů na knížete, ale ted' je rozhodnuta jej povolat zpět, poněvadž se k ní dostaly informace, že jeho vychovatel Felician Wąsowicz špatně disponuje se svěřenými prostředky a činí zbytečné výdaje. Královna se rozhodla pozvat je $\mathrm{k}$ sobě, aby mohla být provedena revize účtů a prověreny pokroky ve vzdělání knížete. Po revizi měli společně s mladíkovým strýcem rozhodnout o dalším způsobu výchovy jejich svěřence.

Královnin názor na Wąsowicze byl nepochybně zkreslený, nebot' sám kníže Michal byl se svým preceptorem velmi spokojen. Již jako král svěril do jeho péče svou pokladnici a na smrtelném loži učinil v poslední vůli ustanovení v jeho prospěch. $V$ testamentu děkoval za to, že mu od raného mládí věrně sloužil, svědomitě vykonával svěrené povinnosti a úkoly a ukládal své manželce, aby jej za všechny dobré skutky dostatečně odměnila. ${ }^{136} \mathrm{~V}$ pozdějších dovětcích mu odkázal 26000 zlatých, diamanty zdobený kord a kočár s postrojem. ${ }^{137}$ Tehdejší narevský starosta ${ }^{138}$ byl jednou z nemnoha králem podobně obdarovaných osob. Dodejme, že chudým králem, protože i současníci Michalu Wiśniowieckému vytýkali, že jeho testament byl zcela nekrálovský a skromný. ${ }^{139}$ Svědčí to tedy o vysokém mínění, které o Wąsowiczovi měl, a hluboké vděčnosti za léta jeho péče. Dodejme rovněž, že Felician Wąsowicz dodal na výchovu krále 60000 zlatých z vlastního majetku a po jeho zvolení se zadlužil, aby mohl odpovídajícím způsobem přijímat jeho straníky. Když už získal úřady starosty szczurovského, novojerozolimského a narevského, disponoval značnými důchody, které věnoval na výchovu šlechtické mládeže. ${ }^{140}$ Takový člověk byl knížeti Michalovi nepochybně dobrým mentorem a soud Ludviky Marie mu jistě křivdil.

\footnotetext{
134 K. BERÁneK (ed.), Magistri, baccalaueri, s. 3-4.

135 AGAD AZ 1107, s. 5.

136 AGAD AWR 1610, s. 3-4.

137 I. CZAMAŃSKA, Wiśniowieccy, s. 288.

138 K. NiesieCKI, Herbarz polski, IX, Lipsk 1842, s. 246-247. Niesiecki ve svém erbovníku uvádí, že Felician Wąsowicz se jako dvořan těšil velké podpoře a sympatiím Michala Korybuta.

139 W. Kochowsкi, Roczników polskich klimakter, IV, s. 325.

140 T. ŻYCHLIŃSKi, Złota księga szlachty polskiej, V, Poznań 1883, s. 405.
} 
Kníže Wiśniowiecki nakonec opustil Prahu v posledních dnech dubna roku 1660. Jeho průvod se 15. května, tedy v době, kdy se na pražském vysokém učení ještě přednášelo, v poledne setkal v Piotrkově s Maxmiliánem Jeronýmem Ossolińským ${ }^{141}$ vyjíždějícím na cestu po Evropě. Dosud se soudilo, že k návratu knížete došlo kolem 19. června. ${ }^{142}$ V rekonstrukci dalších osudů mladého knížete badatelé využívali především první dopis, který Michal Wiśniowiecki už z polského území zaslal svému strýci Janu Zamojskému s poděkováním za jím prokázanou pomoc a péči. ${ }^{143}$ Díky relaci Ossolińského bylo možné mnohem přesněji stanovit datum návratu knížete do země. Poté bylo rozhodnuto vyslat jej na vídeňský dvůr, kde měl údajně sloužit v císařském vojsku v hodnosti plukovníka a dokonce získat titul císařského komořího. ${ }^{144}$ Po odchodu z vídeňského dvora měl pobývat u saského kurfiřta v Drážd'anech. Jeho postavení na habsburském dvoře pravděpodobně nebylo až tak významné, protože podle svědectví papežského nuncia Galeazza Marescottiho získal hodnost plukovníka až po návratu do Polska. ${ }^{145}$ Také Ilona Czamańska ve své monografii uvádí, že v rámci výzkumu ve vídeňských archivech nenalezla žádné svědectví o větší důležitosti pobytu knížete ve Vídni. ${ }^{146}$

Tolik polské prameny a historiografie. O charakteru studia knížete v Čechách vypovídají mnohem více prameny domácí, protože zachycují, byt'v dosti obecné rovině, jakých přednášek se účastnil a jaké mohly být jeho pokroky ve studiu. Bohužel se nedochovaly žádné soudobé prameny týkající se př́mo studia Michala Wiśniowieckého v Praze. Disponujeme ale dvěma později vzniknuvšími prameny, které problematiku do značné míry osvětlují. Je ale nutné předem zdůraznit, že jejich vznik ex post je důvodem ke zdrženlivosti při jejich hodnocení v porovnání se soudobými polskými prameny, vznikajícími bezprostředně během studia Michala Wiśniowieckého. Jedná se o staré tisky uložené v Archivu Univerzity Karlovy, konkrétně o dílo Antonína Alexandra Franchimonta, syna rektora pražské univerzity, vydané roku 1670 pod názvem Patheno-Sophia sive Virginalis sapientia Catharinae ... Anno vero a partu Virginis M.DC.LVIII a Michaele Serenissimo \& Potentissimo Polon: Rege aemula pietate philosophis Pragensibus in sua effigie in venerationem proposita eidemque Maiestati Affectu reverendissimo iterum consecrata ${ }^{147}$ a spis Martina Xavera Volckmana z roku 1672 Gloria Universitatis Carlo-Ferdinandeae Pragensis. ${ }^{148}$

Volckmanovo dílo je svého druhu panegyrikem pražské univerzity, jemuž je výčet slavných a významných mužů studujících na vysokém učení důvodem k pýše a radosti. O studiích Michala Korybuta se nedozvídáme žádné konkrétnější údaje, zdůrazňuje se především čest, kterou univerzitě svým studiem král prokázal. Spis obecně informuje o tom, že jeho studium trvalo čtyři roky, během nichž vynikal výmluvností a dalšími rétorickými dovednostmi. Měl zvládnout celou filozofii, vlastnoručně psát filozofická díla a pilně studovat, aniž by výuku někdy zameškal. Jeho cílevědomost a samostatnost měla vzbuzovat všeobecný obdiv. Se souhlasem profesorů právnické fakulty získal učitele, který jej vzdělával

\footnotetext{
141 Łucjan Tatomir, Dziennik podróży po cudzych krajach odbytej w latach 1660-1663, Biblioteka Ossolińskich. Poczet Nowy, V, 1864, s. 314.

142 A. Przyboś, Michat Korybut Wiśniowiecki, s. 27.

143 AGAD, AZ 1160, s. 3.

144 A. PrZyBoś, Michał Korybut Wiśniowiecki, s. 27.

145 Opisanie dworu, rzeczpospolitej, s. 386.

146 I. CZAmańsKa, Wiśniowieccy, s. 251.

147 AUK, f. SST, č. 310.

148 M. X. Volkman, Gloria Universitatis, s. 72-74.
} 
v právu. Byl jím Ignác Tam, pozdější sekretář na císařském dvoře ve Vídni, díky němuž budoucí král nabyl širokých a nadčasových znalostí a svému učiteli tím zajistil nesmrtelnou čest a věhlas. Jistě stojí za bližší zmínku, že Ignác Tam byl tehdy pouze mistrem filozofie a studentem práv, ${ }^{149}$ a teprve $\mathrm{v}$ roce 1659 vydal svou práci vedoucí $\mathrm{k}$ získání licenciátu práv. ${ }^{150}$ Zajímavá je také skutečnost, že Tam pocházel z Nisy, tedy z města, kde Michal Korybut v roce 1655 studoval $v$ jezuitské koleji na náklady polského královského páru. ${ }^{151}$

Když už hovoříme o učitelích mladého knížete, nemůžeme opomenout osobu Bartoloměje Christelia - jezuitského profesora, který v letech 1657-1660 přednášel na filozofické a teologické fakultě pražské univerzity filozofii, literaturu, logiku, fyziku, metafyziku a etiku. ${ }^{152} \mathrm{~V}$ polské historiografii se setkáme s tvrzením, že jedním z pražských vyučujících knížete Michala byl právě Christelius. ${ }^{153}$ Tento údaj se opírá o biografický záznam ve slavné Bibliothèque de la Compagnie de Jésus, ${ }^{154} \mathrm{kde}$ jsou vedle krátkého jezuitova biogramu uvedeny také historické prameny, v nichž se objevuje jeho jméno. Jedním z těchto pramenů, uvedeným hned na prvním místě, je grafika nesoucí název Celsissimus ac Excellentissimus Princeps DD. Michael Thomas Korybouth, Dux in Wisniowietz et Lubnie, Princeps Wisnievieccius terrarum Rusiae Palat: in Alma Caesarea Regiaque Universitate Pragensi studium Philosophicum $A^{\circ} 1656$ ingressus, cursum feliciter consummavit $A^{\circ}$ 1659. Aetatis suae 19no. Sub Professore R. P. Batholomeo Christelio, Societ: Jesu. AA. LL. et Phiae Doctore. Dochované exempláře grafiky jsou v současné době uloženy $\mathrm{v}$ Germanisches Nationalmuseum v Norimberku ${ }^{155}$ a v Österreichische Nationalbibliothek ve Vídnii ${ }^{156}$ a polským badatelům dosud nebyly známy. Představují pramen, který nepochybně potvrzuje údaj, že Christelius knížete osobně vyučoval. Zároveň jsou také zajímavým ikonografickým pramenem představujícím mladého knížete. Údaje uvedené na grafice je třeba posuzovat stř́zlivě, protože slovní spojení „,cursum feliciter consummavit“ je možné interpretovat nejspíše jako př́ležitostné vyslechnutí výkladů profesora knížetem, a to tím spíše, že Volckman Christelia neuvedl mezi Korybutovými učiteli.

Pozornost je ale třeba věnovat i samotné grafice. Má rozměry $16,8 \mathrm{~cm}$ na délku a $11,5 \mathrm{~cm}$ na šiřku. Zobrazuje mladého knížete Michala, který je oděn v plnou plátovou (kyrysnickou) zbroj, v pravé ruce drží maršálskou hůl a k levému boku má připásaný kord. Pod podobiznou knížete je uveden název díla a informace o autorech, jimiž byli německý rytec Mathäus Küsel a český maliř Karel Škréta, který nakreslil předlohu. Je možné, že na základě tohoto projektu měl vzniknout portrét knížete Michala, který byl u Škréty zamluven. Je ale známo,

\footnotetext{
149 AUK, f. Matriky, M 6, fol. 36r.

150 Josef TřišKa, Disertace pražské univerzity 16.-18. století, Praha 1977, s. 35.

${ }^{151}$ I. CZAmańsKa, Wiśniowieccy, s. 251.

152 Bartoloměj Christelius se narodil v roce 1624 v Mohelnici na Moravě. Do jezuitského řádu vstoupil v roce 1642. Noviciát vykonal v Brně. Působil postupně jako profesor na pražské univerzitě (1657-1660), rektor koleje ve Vratislavi (1663-1666), regent semináře v Chomutově (1667), regent semináře v Olomouci (1677-1679), český provinciál jezuitského řádu (1682-1686), představený profesního domu v Praze na Malé Straně (1686-1689), rektor koleje v Telči (1691-1694) a rektor pražské jezuitské koleje (1700-1701). Autor poezie, modliteb, překladů z latiny do němčiny a vědeckých děl. Zemřel v roce 1701 v Praze. Srov. Charles Sommervogel, Bibliothèque de la Compagnie de Jésus, II, Bruxelles - Paris 1891, kol. 1159-1163; Dieter Breuer, Der Zodiacus Laetofatalis des Bartholomäus Christelius SJ und die jesuitische Meditationsliteratur, in: Petronilla Čemus (ed.), Bohemia Jesuitica 1556-2006, II, Praha 2010, s. 795-796.

153 A. Markiewicz, Podróże edukacyjne, s. 111.

154 C. Sommervogel, Bibliothèque, kol. 1159-1163.

155 Germanisches Nationalmuseum, Graphische Sammlung, sign. MP 13021a.

156 Österreichische Nationalbibliothek, Bildarchiv, sign. 75308.
} 
že obraz nakonec nevznikl, i když se kontakt s malířem ukázal jako plodný (o tom podrobněji dále).

V další části Volckman tvrdí, že „,v myslích všech zůstane uchována pamět' královských ctností a dlouho v nich bude žít vzpomínka na něj“. 157 Poté následují přání, aby Wiśniowieckého potomci zdědili jeho vlastnosti, aby se království dočkalo úspěchu a triumfů nad nepřáteli a aby královský rod rostl a sílil. Na konci grafiky je umístěna elegie k poctě polského krále, v níž se uvádí, že Michal Korybut přinesl pražským učencům slávu a univerzitě lesk. Kromě toho autor poukazuje na skutečnost, že pero, kterým psal svá filozofická díla, nyní vyměnil za šavli, jíž porazí turecké nepřátele pro slávu Polska a ochranu církve. Elegii stojí za to uvést v originálním znění, aby bylo zřejmé, nakolik byla univerzita na svého studenta hrdá:

\author{
ELEGIUM SERENISSIMI \\ REGIS POLONIAE \\ Flos Principum, (a) Sanctorum propagao, (b) Jagellonidum \\ Germen, (c) Regum Prosapia, (d) Caesarum sanguis et Amor. \\ MICHAEL Poloniae Rex Serenissimus. \\ Academicorum Pragensium Gloria, \\ Universitatis Carolo-Ferdinandae splendor. \\ In qua \\ Sic quadriennali decurrit studio, ut a tot suspiceretur, \\ a quot aspiceretur. In rostris Romanis industrius, \\ In pluvere Philosophico Athleta, utrobique \\ Heros \\ Utramque Palladem sic sociatam habet; ut nescias utra \\ dextram, utra stipet sinistram. \\ Qua nunc arma in hostes vibraturus est, ea ipsa manu, tam \\ constanter calamos tractavit, ut apices omnes \\ Philosophicos ipse scripserit. \\ Vertantur nunc hi calami in acinaces, quibus Ottomanici \\ intereant Luniferi! \\ Sed quid ego enses voveo? \\ Unus, sta pro Polonia, pro Coelo, pro Ecclesiae praesidio! \\ Hoc aditum ad corrumpendam Religionem Lu- \\ nato interclude Hosti \\ Coelestis Cherubine! $!^{158}$
}

Uvedená zmínka o šavli svědčí, jak trefně konstatoval Vladimír Závodský, o daru, který v červnu 1672 králi věnoval papež Klement X. v souvislosti s jeho aktivitami ve prospěch protiturecké ligy, čili o papežském meči. ${ }^{159}$ Jednalo se o neobvyklý dar, který byl udělován jen zrrídka i z toho důvodu, že jej mohl posvětit pouze papež na den Kristova narození

157 M. X. Volkman, Gloria Universitatis, s. 73.

158 Tamtéž, s. 73-74.

159 V. Závodskŕ, Rytina obrazu, s. 116. 
v římské bazilice svatého Petra. ${ }^{160}$ Je třeba dodat, že královna Eleonora rovněž získala od papeže dar, mistrovsky provedenou zlatou růži, která se ale stejně jako papežský meč nedochovala.

Franchimontův spis je na údaje o studiu Michala Korybuta mnohem chudší. Obsahuje ovšem informace o zásnubách polského krále se sestrou samotného císaře Leopolda I. Eleonorou Habsburskou. Autor je mimořádně hrdý na to, že bývalý student pražského vysokého učení nejenže se stal králem, ale sňatkem s císařovou sestrou také členem císařské rodiny. ${ }^{161}$

Mnohem více prostoru je věnováno nezvyklému daru, který v roce 1658 Michal Korybut věnoval pražské univerzitě. Byl jím proslulý obraz svaté Kateřiny Alexandrijské (olej na plátně, rozměry $233 \times 143,5 \mathrm{~cm}$ ), patronky filozofické fakulty, jehož autorem byl otec českého barokního malířství Karel Škréta. Obraz byl uveden mezi jinými předměty v univerzitním inventáŕi z roku 1673 (in aula magna Carolinae sunt dua imagines, una S. Joannis, altera S. Catharinae, manu domini Screta picta). ${ }^{162}$ Zdobil tehdy univerzitní Velkou aulu, ${ }^{163}$ společně se dvěma dalšími maliřskými díly, z nichž se dodnes dochoval pouze jeden (obraz svatého Jana Evangelisty, patrona teologické fakulty). ${ }^{164}$ Franchimont uvádí, že tento dar byl svědectvím zbožnosti a velkomyslnosti dárce. ${ }^{165}$ Obraz sv. Kateřiny je dnes umístěn v reprezentačních prostorách Karolina a je považován za jeden z nejcennějších a nejkrásnějších exponátů ve sbírkách Univerzity Karlovy, ačkoli otázka Škrétova autorství byla předmětem mnoha diskusí. ${ }^{166}$

Franchimont do svého panegyriku umístil i věrnou reprodukci obrazu svaté Kateřiny, jejímž autorem je německý grafik Johann Friedrich Leonart. Rytina je po obsahové stránce značně bohatší než původní obraz. Svatá Kateřina je na ní prezentována jako mladá kněžna sedící na vyvýšeném místě se zrakem upřeným na stranu diváka. Pod jejíma nohama jsou umístěny atributy spojované s patronkou věd (dalekohled, kvadrant, kružítko, zrcadlo) a s její mučednickou smrtí (katovské kolo jako nástroj k lámání končetin). Světice drží v levé ruce meč a palmovou ratolest a její pravá ruka spočívá na otevřené knize s latinským textem listu svatého Pavla Římanům (Řím 1, 19-22). Za ní se na nízkém stole nachází astroláb, zemský a nebeský glóbus a postava ženy na vyvýšenině v podobě stupňů pyramidy. Napravo od svaté Kateřiny je umístěn zdobený pultík s velkou knihou, který má podobu ženy podepírající pravou rukou knihu a levou rukou heraldickou kartuši s Franchimontovým erbem. Pod ním je podstavec pultíku s uvedením autora obrazu a grafiky (Carl Screta p. / J. F. Leonart sc $A^{\circ} 1670$ ). Celek kompozice je uzavřen ozdobným rámem, který drží početní putti. Ve středu horního rámu se nachází erb s polským orlem v koruně, který má na prsou štítek s vyobrazením erbu Korybut a Řádem zlatého rouna, štítek zdola obepínající. Pod dolní částí rámu je umístěna veduta Prahy a nápis: „S. CATHARINA V. at M. primum ab Angelis in Monte Sinai, Anno vero 1658 a MICHAELE, Serenissimo et Invictissimo Poloniae Rege aemulu[m] pietate in Universitate Pragensi Philosophis in venerationem

\footnotetext{
160 Jerzy LiLeYкo, Regalia Polskie, Warszawa 1987, s. 123.

161 AUK, f. SST, č. 310, p. XII-XIV.

162 Diplomatarium universitatis Pragensis (statuta universitatis, statuta collegii Carolini, miscellanae) 1360-1676. AUK, fond Rukopisy, sign. A 12 II, Praha, p. 130-136.

163 Josef Petrán̆, Obrazové soubory v Karolinu, in: J. Petráň (ed.), Památky Univerzity Karlovy, Praha 1999, s. 255.

164 L. SToLÁrová - V. Vlnas, Karel Šréta, s. 232-233.

165 AUK, f. SST, č. 310, p. III-IV.

166 J. Petréñ Díla Karla Škréty v Karolinu, Folia Historica Bohemica 10, 1986, s. 421-435.
} 
data“. Prvky přidané na rytině navíc oproti původnímu obrazu jsou především kartuše s Franchimontovým znakem, informace o autorství obrazu a rytiny na podstavci pultíku a všechny prvky nacházející se vně rámu a na něm.

Odhlédneme-li od zmínek, týkajících se doby, kdy Michal Korybut studoval v Praze, stojí za úvahu tak pozdní zájem o někdejší pobyt budoucího krále v Čechách. Urozený původ a postavení Michala Korybuta pražským elitám určitě nemohly ujít. Přece jen byl protežovaným chráněncem krále Jana II. Kazimíra a díky královně Ludvice Marii mohl začít se studiem v Praze. ${ }^{167} \mathrm{~V}$ žádném dobovém dokumentu týkajícím se osob studujících nebo imatrikulovaných na pražské univerzitě se ale údaje o něm neobjevují. Nepochybně to svědčí o tom, že budoucí král během pražských čtyř let nezískal žádný akademický titul, ač $\mathrm{k}$ tomu disponoval dostatkem času. Jeho osoba zjevně nebyla natolik zajímavá, aby vedení univerzity nějakým způsobem zachytilo jeho př́tomnost na vysokém učení. Dodejme, že ani výše zmíněný pozdější pobyt knížete na vídeňském dvoře se v tamějších pramenech neprojevil, ačkoli pobýval u sestřenice své polské protektorky, císařovny Eleonory.

Zájem o jeho osobu vzrostl teprve po deseti letech, což bylo nepochybně důsledkem korunovace Michala Korybuta na polského krále v roce 1669 a jeho zásnub s císařovou sestrou. Tyto události vzbudily ve vedení univerzity pýchu a chut' pochlubit se významným studentem. V listopadu 1670 se navíc v Praze odehrály slavnosti k poctě svaté Kateřiny a v této souvislosti byl vydán Franchimontův spis, $v$ němž se vzpomínka na dárce cenného obrazu nutně musela objevit. ${ }^{168}$ Odtud tedy pocházejí informace o studiu Michala Korybuta v Praze.

Přesto se ale v Korybutově prípadě jednalo o více, než o pouhou výchovnou cestu bez zřetele k získání akademických gradů. Zdá se, že co do formy studia byl kníže př́ležitostným, formálně neevidovaným posluchačem. Významná je také skutečnost, že jeho učitel práva Ignác Tam byl student a za výuku byl nejspiše placen. Nejednalo se samozřejmě o nic nezvyklého, protože i samotní profesoři právnické fakulty vynikali ve vedení placených kurzů mimo univerzitní výuku. Snad to byla právě tato praxe, která společně s výlety mimo Prahu a koupí cenného obrazu vedla k nářkům Ludviky Marie na př́liš vysoké náklady ve prospěch mladého knížete. Vedení univerzity se zase s odstupem několika let nemohlo negativně vyjadřovat o králi sousedního státu a švagrovi panujícího císaře, v důsledku čehož vznikl popis studia polského krále překypující superlativy, aniž by v něm byly podány konkrétní údaje o jeho průběhu. Dříve se zmínky o pobytu budoucího polského krále v Praze nejspíše neobjevovaly proto, že nebyl považován za zajímavý, stejně jako jeho spojitost s pražským vysokým učením. To samožrejmě neznamená, že bychom měli studijní výsledky knížete Michala Wiśniowieckého bagatelizovat, protože jsou v obecné rovině dobře známy (pravděpodobně uměl až osm jazyků a přinejmenším v pěti z nich byl schopen vést korespondenci). Jeho cesta za vzděláním, a to nejen její pražská etapa, si zaslouží další pramenný výzkum, který může přinést nové důležité informace, jež umožní přesnější pohled na jeho nadání ke studiu a studijní výsledky.

167 A. PrzyBoś, Michat Korybut Wiśniowiecki, s. 26.

168 V. ZÁvodsKÝ, Rytina obrazu, s. 116-117. 


\section{Role absolventů pražské univerzity v sociálně-politickém životě Rzeczypospolité}

Dalším důležitým aspektem spojeným se studiem osob z Rzeczypospolité na pražské univerzitě, který chceme ukázat, je otázka, nakolik měly vědomosti a akademické tituly získané v Praze vliv na životní osudy absolventů. Zpracování tohoto tématu je komplikované, protože v mnoha případech nelze jednoznačně říci, zda byla následující úřední, vojenská, vědecká nebo politická kariéra determinována právě vzděláním na pražském vysokém učení. Je to zvláště patrné v případě studentů, kteří pocházeli ze šlechtických rodů, především těch zámožných a známých. V zásadě nemuseli dosáhnout akademického gradu, protože obvykle dědili majetky po svých předcích a měli tedy větší šance na získání zemských úřadů. Lze to sledovat na prŕíkladu několika studentů, kteří se, ačkoli neměli akademický titul, zapsali do dějin Rzeczypospolité mnohem významněji než jejich po formální stránce vzdělanější, ale méně zámožní kolegové. Zároveň ti z nich, jimž více záleželo na dosažení úplného vzdělání, obvykle doplňovali své znalosti nabyté v Praze na dalších zahraničních nebo polských vysokých školách, prrípadně naopak - vzdělání získané jinde si doplňovali v Praze.

Takový ambivalentní př́ístup k vyššímu vzdělání byl typický pro studenty šlechtického původu, kteři jakožto příslušníci vůdčích vrstev Rzeczypospolité měli lepší podmínky pro osobnostní rozvoj, a proto lze těžko stanovit, nakolik jim studium v Praze bylo v dalším životě užitečné. Nejvýznamnějším př́kladem je určitě osobnost Michala Korybuta Wiśniowieckého, který se králem Rzeczypospolité jistě nestal pro své dřívější studijní výsledky, ale hlavně kvůli slavnému otci, troše štěstí a možná i z jistého rozmaru šlechty shromážděné na volebním poli ve Woli u Varšavy.

Na druhé straně je v případě studentů měšt’anského původu možné vysledovat, že vzdělání získané v Praze bylo pravděpodobně dosti důležitým katalyzátorem změn v jejich společenském postavení a přispělo k tomu, že získali mnohem výnosnější funkce. Většina studentů měšt'anského původu je ale v pramenech těžko zachytitelná, proto bude míru pravdivosti tohoto tvrzení ještě nutné upřesnit. Každopádně přinejmenším pro část studentů měšt’anského původu se podařilo poměrně podrobně rekonstruovat postup jejich kariéry na poli úředním nebo církevním, a je tedy přinejmenším per analogiam možné předpokládat, že uvedené tvrzení v obecné rovině platí.

Již mnohokrát bylo zmíněno, že se podařilo zjistit jména stovky studentů, kteří studovali na pražské univerzitě v 17. a 18. století. Vzhledem k tomu, že jejich biogramy jsou umístěny v př́loze, soustředíme se na představení kariér jen u menší části z nich, zato reprezentativnějších a v pramenech lépe doložených, př́ípadně u osobností, jež měly reálný vliv na sociálně-politickou situaci a jež by byla škoda sledovat pouze v rámci statistiky. Z pochopitelných důvodů se nebudeme dále zabývat Michalem Korybutem, protože jeho další osudy jsou povšechně známé. Začneme Kryštofem Antonínem Szembekem, ${ }^{169}$ primasem polským z let 1739-1748.

Kryštof Antonín Szembek, narozený roku 1667, pocházel ze známé a zasloužilé šlechtické rodiny. Jen mezi jeho nejbližšími příbuznými byli primas, tři biskupové, velký korunní kancléř, jeden kastelán a jeden vojevoda. Měl tedy podstatně snadnější vstup do života než

169 J. KoRYTKOWSKI, Arcybiskupi gnieźnieńscy, s. 545-572. 
většina jeho vrstevníkủ a budoucí kariéru předem zajištěnou, ačkoli jeho další osudy svědčí o tom, že ji opíral o mimořádné vzdělání a své funkce i ocenění si zasloužil také osobní angažovaností a viditelnými pracovními výsledky. Než se dostal na pražskou univerzitu, studoval teologii a právo v Krakově a v Římě, kde získal titul doktora práv. Roku 1692 byl vysvěcen, záhy se stal kanovníkem kujavským (1694), přemyšlským (1699) a kustodem v Łowiczi (čestný titul kustoda v tomto smyslu náležel kanovníkovi spravujícímu majetek kapituly). ${ }^{170}$ Mimořádně zajímavé ale je, že titul mistra filozofie na pražské univerzitě získal 13. srpna 1699, ${ }^{171}$ tedy již v době, kdy disponoval titulem doktora práv z Říma.

Na př́íkladu Kryštofa Antonína Szembeka je dobře vidět, že akademické tituly získané na západních univerzitách, zvláště italských, nemusely být zárukou odpovídajícího vzdělání. Řada západních vysokých učení totiž stanovovala velmi nízké platby za zkoušky a získání akademických gradů na nich proto bylo mnohem snadnějši - vynikaly tím zvláště univerzity italské. ${ }^{172}$ Není tedy nic zvláštního na tom, že si mnozí prèedstavitelé šlechtického stavu zvolili tuto mnohem snazší cestu za vzděláním. Szembekův př́íklad ukazuje, že se přese vše rozhodl pro doplnění svého italského vzdělání, patrně protože cítil, že pro jeho osobu a budoucí kariéru v církevní správě není dostatečné. Jeho kariéra byla mimořádně rychlá a důstojná, a to nejen co se týká získávání dalších „příček na žebříku“ v rámci církevní hierarchie či prebend, ale také v oblasti politiky. Kryštof Antonín Szembek se stal mimo jiné sekretářem krále Augusta II. a velkým korunním referendářem (1709-1710), a také diplomatem. Jako vyslanec putoval v tureckých a slezských záležitostech např́klad do Vídně (1713-1714) nebo k carovi do Moskvy. Vedle toho se účastnil práce sejmových komisí či politických sporů v době bezkráloví roku 1733 a války o dědictví polské (nejprve na straně Augusta II., v roce 1733 jako straník Stanislava Leszczyńského, aby v roce 1736 nakonec uznal Augusta III.). ${ }^{173}$

Navzdory světské kariéře se ale Szembek mnohem více zapsal do dějin jako vysoký církevní hodnostáŕ. Postupně získával další důchody, pocty, prebendy a církevní funkce (kanovník varmijský, hnězdenský, varšavský, katedrální probošt ve Fromborku, probošt v Královci, oficiál gdaňský a arciděkan pomořanský), až se stal biskupem livonským (1711), poznaňským (1716), kujavsko-pomořským (1719) a nakonec arcibiskupem hnězdenským, a tedy primasem polským a litevským. Jeho duchovní a charitativní činnost svědčí o tom, že nehledě na své majetkové a politické zázemí byl především dobrým knězem a duchovním pastýřem katolické církve (nechal vystavět a vybavit špitál pro sirotky ve Varšavě a na samém počátku své církevní kariéry působil jako probošt v rodném Szczepanově). ${ }^{174}$

Szembekův př́klad jasně ukazuje, že vzdělání získané v Praze bylo pro jeho budoucí kariéru užitečné. Skutečnost, že pražský titul mistra filozofie získal až po ukončení studií v Krakově a Římě evidentně svědčí o tom, že akademické grady pražské univerzity měly

170 T. Oracki, Stownik biograficzny Warmii, Prus Ksiązęcych, s. 175.

171 AUK, f. Matriky, M 22, p. 287, 290.

172 M. LORET, Polskie pielgrzymstwo naukowe, s. 131.

173 Antoni GąsIorowsKi (ed.), Urzędnicy centralni i nadworni Polski XIV-XVIII wieku. Spisy, Kórnik 1992, s. 140; K. NieSIECKI, Herbarz Polski, VIII, Lipsk 1841, s. 615-616; T. ŻYCHLIŃSKI, Zlota księga szlachty polskiej, I, Poznań 1879, s. 296-297; S. KossaKowski, Monografie historyczno-genealogiczne, III, Warszawa 1872, s. $263-265$.

174 Piotr Nitecki, Biskupi Kościoła w Polsce. Stownik biograficzny, Warszawa 1992, s. 200; Hierarchia catholica medii et recentioris aevi sive summorum pontificum - S. R. E Cardinalium ecclesiarum antistitum series..., V, Patavium 1952, s. 322, 408, 418. 
svůj význam. Nemůžeme samozřejmě přesně zjistit, proč si Szembek zvolil právě tuto cestu k získání vyššího vzdělání. Není vyloučeno, že svůj studijní pobyt v Praze osobně považoval v tomto směru za nutnost, protože, jak bylo výše ukázáno, rodina mu mohla zajistit odpovídající posty i bez něj. Vzhledem k nedostatku jednoznačných informací v pramenech tak lze připustit i tezi, že pražské studium sehrálo v Szembekově životě větší roli, než by se na první pohled mohlo zdát.

Dalším př́íkladem, který tuto tezi může podpořit, je osoba Jeronýma Rotha ${ }^{175} \mathrm{z}$ Královce v Knížecích Prusích. Také v jeho př́ípadě je na místě hovořit o jisté ambivalenci získaného vzdělání. Jeroným Roth byl sice obyvatelem Knížecích Prus, a tím pádem státního útvaru na Rzeczypospolité nezávislého, ale podle mínění autora jej nelze v této studii opomenout, protože vyrůstal ještě v době, kdy Knížecí Prusy byly lénem Rzeczypospolité (narodil se roku 1635 a Knížecí Prusy získaly nezávislost v roce 1657). Vedle toho svými politickými aktivitami prokázal, že polsko-litevské soustátí mu bylo bližší.

Jeroným Roth byl synem slavného stejnojmenného vůdce měšt’anské opozice v Knížecích Prusech a Barbory Fahrenheit. Kvůli odlišení od otce býval nazýván Rothem mladším. Na pražské univerzitě studoval na právnické fakultě v roce 1659. ${ }^{176}$ Po návratu domů se angažoval v politice. Vzhledem k otcovým sympatiím k polskému dvoru vstoupil v roce 1661 do služeb vojevody Michala Korybuta Wiśniowieckého jako jeho sekretár. Souběh dat nás nutí domýšlet se, že mladý Roth pobýval v Praze ve stejné době jako Michal Korybut, kterého tam jistě poznal, zvláště když oba studovali na té samé fakultě. Lze tedy tvrdit, že začátek jeho kariéry souvisel se staršími kontakty a vlivem otce. Jeroným Roth byl po celou dobu otcových opozičních aktivit proti braniborskému kurfiřtovi jeho plnomocníkem. Jménem otce a pruských stavů často vystupoval jako vyslanec u polského krále s prosbami o podporu jejich emancipačního úsilí a rozhodnou diplomatickou, či př́mo vojenskou pomoc. Kurfiřt Fridrich Vilém I. ale za pomoci generálního místodržitele Knížecích Prus, knížete Bohuslava Radziwiłła, v roce 1662 Jeronýma Rotha staršího zajal a uvěznil, čímž vzpouru pruského měšt’anstva zpacifikoval. ${ }^{177}$

Jeroným Roth mladší se své opoziční činnosti přesto nevzdal. V záležitosti svého otce pravidelně intervenoval na polském dvoře a stal se dokonce agentem polského dvora (pseudonym „,czerwony“). Z tohoto důvodu od roku 1663 dočasně pobýval ve Zwierzyńci u Zamośče v letní rezidenci Zamojských, odkud polský dvůr informoval o kontaktech Jiř́ho Lubomirského s Bohuslavem Radziwiłłem. Když pokusy o otcovo osvobození skončily fiaskem, vydal se Jeroným Roth v roce 1673 do Varmie ke svému strýci, jezuitovi Bernardovi. Během pobytu u jezuitů se nadále těšil podpoře polského dvora, konkrétně krále Jana III. Sobieského, ale po otcově smrti ve vězení v roce 1678 se z politického života zcela stáhl a jeho další osudy nejsou známé. ${ }^{178}$

175 Karl Lohmeyer, Roth Hieronymus, in: Allgemeine Deutsche Biographie 29, Lipsk 1889, s. 311-312; Fritz Gause, Roth Hieronymus, in: F. Gause, Kurt Farstreuter (Hgg.), Altpreußische Biographie II/4: PolenzSsdorski, Marburg - Lahn 1961, s. 572.

176 AUK, f. Matriky, M 6, fol. 43v-44r; tamtéž, M 12, fol. 69r.

177 Christopher Clark, Prusy. Powstanie i upadek 1600-1947, Warszawa 2009, s. 79-80; Karl Friedrich, The Other Prussia. Royal Prussia, Poland and Liberty 1569-1772, Cambridge 2000, s. 49; Kazimierz PIWARSKI, Dzieje Prus Wschodnich w czasach nowożytnych, Gdańsk - Bydgoszcz 1946, s. 147, 149, 152, $165,195$.

178 T. Oracki, Słownik biograficzny Warmii, Mazur, s. 244-246; T. Oracki, Słownik biograficzny Warmii, Prus Książęcych, s. 118-120; Bogusław Radziwıt, Autobiografia, ed. Tadeusz Wasilewki, Warszawa 1979, s. 84-89, $150-151,164-165$. 
Szembek a Roth tak vedle Michala Korybuta představují nejznámější osobnosti mezi studenty z Rzeczypospolité, kteří v 17. a 18. století studovali na pražské univerzitě. Ovlivňovali soudobé politické dění na úrovni celé země a významně se zapsali do dějin polsko-litevského soustátí. Následující skupina studentů zahrnuje osoby obtížně identifikovatelné, ale stále ještě náležející do okruhu historických osobností významných alespoň na regionální úrovni. Jedná se vesměs o př́slušníky šlechtického stavu jakožto držitele různých, zpravidla méně důležitých zemských úřadů. Jejich společenské a politické postavení záviselo především na tom, z jak majetného rodu pocházeli, a jen v menší míře na jejich vzdělání. Ve většině prŕípadů tedy není možné zjistit, nakolik jim studium v Praze posloužilo pro následující úřrední kariéru.

Jan Alexandr Baranowski erbu Grzymała z Piętkowa na Podlesí, bakalár filozofické fakulty z roku 1690, ${ }^{179}$ byl například jmenován litevským podčeším v roce 1693, tedy nedlouho po návratu ze zahraničních studií. ${ }^{180}$ Funkci volitele během volby Augusta II. Silného zastával Štěpán Przespolewski erbu Topór z Bieganina ve Velkopolsku, student právnické fakulty (1682). ${ }^{181}$ To je ale jediný doklad jeho úřední kariéry - snad proto, že si jakožto dědic dvou statků (Bieganin a Strzebowa) a otec deseti dětí zvolil životní dráhu usedlého zemana. ${ }^{182}$ Dalším pražským absolventem, v tomto př́ípadě s vyššími akademickými grady a jistě také většími ambicemi, byl Tomáš Grądzki z Kubry, erbu Łada, z Mazovska. O jeho větších ambicích svědčí skutečnost, že v roce 1661 získal titul mistra filozofie ${ }^{183}$ a že v souvislosti s jeho promocí byla objednána grafická akademická teze, jejímž patronem se stal budoucí polský primas Andrzej Olszowski. Úřední kariéru začal Tomáš Grądzki jako dvořan Jana II. Kazimíra Vasy v roce 1667. Poté získal hodnost podčešího a od roku 1683 byl starostou wizenským, čímž se stal držitelem jednoho z nejvýznamnějších zemských úřadů, hned po úřadech podkomořího a senátorů (vojevody a kastelána). Ještě než nastoupil do uvedených funkcí, účastnil se v roce 1674 volby Jana III. Sobieského. O vzdělanosti a vážnosti, jíž se mezi šlechtou těšil, dobře svědčí skutečnost, že byl na sejmu roku 1683 jmenován komisařem pro stanovení hranice mezi vojvodstvími mazovským a podleským a knížectvím pruským, ${ }^{184}$ čímž mu byl svěřen velmi závažný úkol.

Dalším úředníkem mezi absolventy pražské univerzity byl Mikołaj z Brzezia Lanckoroński, a tedy, jak sám prrídomek ukazuje, příslušník majetného a urozeného šlechtického rodu erbu Zadora. Oproti výše uvedeným absolventům nezískal žádný akademický titul, pouze studoval na právnické fakultě (1683). ${ }^{185}$ Absence akademických gradů mu ale nebyla překážkou při získání úřadu starosty skalského (podle města Skała Podolska - pozn. překl.),

179 AUK, f. Matriky, M 22, p. 236-237.

180 Antoni GąsIorowski (ed.), Urzędnicy województwa ruskiego XIV-XVIII wieku. (Ziemie halicka, lwowska, przemyska, sanocka). Spisy, Wrocław - Warszawa - Kraków - Gdańsk - Łódź 1987, s. 130; S. URUSKI, Rodzina. Herbarz szlachty polskiej, I, Warszawa 1904, s. 87-88.

181 AUK, f. Matriky, M 6, fol. 85v, 220r; M 12, fol. 63r.

182 S. Uruski, Rodzina. Herbarz szlachty polskiej, XV, Warszawa 1931, s. 24-25; Jozafat Ohryzko (ed.), Volumina legum, V, Petersburg 1860, s. 428; Rody szlacheckie $w$ Wielkopolsce $w$ XVI-XIX w. (ułożone alfabetycznie według nazwisk), P, Archiwum dra Wojciecha Józefa Skowrońskiego (dále AWJS), rkp. 1682, Biblioteka Poznańskiego Towarzystwa Przyjaciół Nauk (dále Biblioteka PTPN), s. 160-161.

183 AUK, f. ÚT KFU, I (1624-1690, 1650-1690), p. 21; AUK, f. Matriky, M 22, p. 65-66.

184 A. BonIECKi, Herbarz Polski, VII, Warszawa 1904, s. 52; S. URuski, Rodzina. Herbarz szlachty polskiej, IV, Warszawa 1907, s. 367; K. Niesiecki, Herbarz Polski, IV, Lipsk 1839, s. 272; J. Oнryzко (ed.), Volumina legum, s. 157, 325.

185 AUK, f. Matriky, M 6, fol. 195v; M 12, fol. 7v. 
který mu byl postoupen strýcem Jeronýmem, podkomořím podolským. Za zmínku stojí, že Mikołaj Lanckoroński byl posledním mužským potomkem starší (jelnické) větve rodu Lanckorońských z Brzezia. ${ }^{186}$ Martin Motowski, student lékařské fakulty z roku 1747, získal úr̆ad starosty jaźnienského ve wieluńském kraji, ačkoli stejně jako Lanckoroński neukončil svá studia získáním akademického titulu. ${ }^{187}$

Podobně na tom byl také Andrzej Zakrzewski, erbu Wyssogota, který se domohl ještě vyšších úrúedních funkcí. V Praze studoval pouze jeden rok (1647/1648), aby poté náhle opustil Čechy a vydal se do války proti Tatarům. ${ }^{188}$ Dne 28 . května 1664 byl jmenován zástupcem stolníka kališského a o dva roky později stolníkem kališským. S velkou pravděpodobností se dočkal také pocty zasednout mezi senátory, protože v roce 1671 byl na místo stolníka kališského navrhován Stanisław Jarczewski, údajně po dalším povýšení Andrzeje Zakrzewského, který se měl stát kastelánem sanockým. Tato otázka ale není přesně prozkoumána. ${ }^{189}$

Tím končí výčet studentů, jimž byly během jejich další kariéry svěřeny některé ze zemských úřadů. Část absolventů pražské univerzity se však $\mathrm{k}$ žádným úřadům nedostala, ačkoli měla vlivné a zámožné rodiče. Byli ale „druhými syny“ a př́slušná důstojenství tak připadla jejich starším bratrům. Mezi takové „druhé syny“ patří mimo jiné Jan Stanislav Cetner, erbu Przerowa, student právnické fakulty (1714). ${ }^{190}$ Byl synem Alexandra, starosty szczurowieckého a tramblowského, později kastelána braclavského, a tím pádem senátora, ačkoli nakonec se uvedeného úřadu neujal. Jan Stanislav Cetner byl dokonce třetím synem v pořadí a z toho důvodu se stal františkánem (1717). ${ }^{191}$ Také student práva z roku 1692 Stanislav Ciświcki, erbu Wieniawa, ze Zbąszyny, ${ }^{192}$ nedosáhl žádných úřadů, ačkoli jeho otec Ludvík byl starostou stawiszyńským. ${ }^{193}$ Je zjevné, že konexe a vzdělání nebyly pro politickou kariéru vším.

Kromě zemských úřadů se absolventi studia na pražské univerzitě uplatnili také v církvi. Zmiňovaný Kryštof Antonín Szembek získal nejvyšší kněžská svěcení a stal se duchovním vůdcem celé Rzeczypospolité. Ostatní působili většinou jako duchovní středního a nižšího stupně, př́ípadně byli řádovými kněžími. Celkově se absolventi pražské univerzity pocházející z polsko-litevského soustátí stali prríslušníky čtyř církevních řádů (františkánů, cisterciáků, cyriaků a samozřejmě jezuitů).

Již zmiňovaný Jan Stanislav Cetner byl františkánem. Protáz Dobrzyński, který se stal členem řádu cyriaků, nenáležel v Praze mezi nejlepší studenty - bezúspěšně se snažil

186 A. BonIECKI, Herbarz Polski, XIII, Warszawa 1909, s. 338; S. Unuski, Rodzina. Herbarz szlachty polskiej, VIII, Warszawa 1909, s. 271; Stanisław CynARski, Dzieje rodu Lanckorońskich z Brzezia od XIV do XVIII wieku, Warszawa - Kraków 1996, s. 150.

187 AUK, f. Matriky, M 63, p. 56; S. URUSкI, Rodzina. Herbarz szlachty polskiej, XI, Warszawa 1914, s. 318.

188 K. BERÁneK (ed.), Magistri, baccalaueri, s. 274.

189 T. Żychliński, Ztota księga szlachty polskiej, I, Poznań 1879, s. 348-349; Antoni GąsıorowsKi (ed.), Urzędnicy wielkopolscy XV-XVIII wieku. Spisy, Wrocław - Warszawa - Kraków - Gdańsk - Łódź 1987, s. 72; Rody szlacheckie $w$ Wielkopolsce $w$ XVI-XIX w. (ułożone alfabetycznie wedlug nazwisk), Z, AWJS, rkp. 1689, Biblioteka PTPN, s. 20.

190 AUK, f. Matriky, M 12, fol. 16r.

191 S. URUSKi, Rodzina. Herbarz szlachty polskiej, II, Warszawa 1905, s. 136-138; A. BonIECKI, Herbarz Polski, II, Warszawa 1900, s. 326-328.

192 AUK, f. Matriky, M 12, fol. 15r.

193 A. BonIecki, Herbarz Polski, III, Warszawa 1900, s. 228; S. URuski, Rodzina. Herbarz szlachty polskiej, II, Warszawa 1905, s. 331-332. 
o postup do druhého ročníku studia na filozofické fakultě. ${ }^{194}$ Do řádu cisterciáků vstoupil Nikodem Tarno, student právnické fakulty v roce 1724, který svou službu vykonával v klášteře v Olivě. ${ }^{195}$ Nositelem vyšších akademických titulů a držitelem význačnějších duchovních úřadů byl Ondřej Kazimír Václav Kuropatnicki, erbu Nieczuja, pocházející ze lvovského kraje. Jako syn kyjevského kastelána Jeronýma Kuropatnického měl zajištěné materiální zázemí pro získání dobrého vzdělání i odpovídajících duchovních úřadů. V roce 1682 byl jako jediný ze zjištěných studentů z Rzeczypospolité promován doktorem filozofie. ${ }^{196}$ Od roku 1691 byl kanovníkem lvovským, až se mu nakonec v roce 1720 dostalo čestné funkce lvovského katedrálního děkana. Kromě toho byl činný na poli soudnictví jakožto několikanásobný člen deputace ke korunnímu tribunálu. ${ }^{197} \mathrm{~S}$ jeho studiem v Praze je spojena jedna nejasnost: ve své disertaci je uveden jako kanovník sandoměřský, ale v katalogu kanovníků sandoměřské katedrály, sestaveném Janem Wiśniewským, se jeho jméno nevyskytuje. ${ }^{198}$

Dalším významným duchovním hodnostářem byl Marcian Junosza Szaniawski, představitel známého litevského rodu, z něhož pocházel nejeden biskup či vysoký zemský úredník. ${ }^{199} \mathrm{~V}$ Praze získal nejprve $\mathrm{v}$ roce 1709 titul bakaláře a o rok později titul mistra. ${ }^{200}$ Po studiích nastoupil do funkce vilenského scholastika, což v praxi obnášelo dozor nad školami v celé diecézi. Následně byl v roce 1717 jmenován velkým (duchovním) sekretářem a tuto funkci vykonával do roku 1728. ${ }^{201}$ Ignác Zakrzewski, mladší bratr již zmiňovaného Ondřeje Zakrzewského, byl zase kanovníkem poznaňským (1678). Na rozdíl od bratra se nevrátil válčit s Tatary, ale byl evakuován z Prahy z důvodu obléhání města švédským vojskem. Kvůli tomu svá studia ukončil již v prvním ročníku filozofické fakulty (1647/1648).202 Protože byl druhým synem Jakuba Zakrzewského a jeho ženy Jadwigy Słupské z Boguszyna, byla mu souzena církevní kariéra, zatímco jeho bratr se stal dědicem rodinného majetku a zemským úř́edníkem. ${ }^{203}$

Podstatně více můžeme povědět o církevní kariéře trojice studentů pocházejících z obce Święciechowa ve Velkopolsku. Jedná se o bratry Martina Ignáce a Jana Karla Zahnovy a jejich společníka z doby pražských studií Jana Krauseho, kteří všichni byli měštanského původu. Než se starší z bratř́ Zahnů Jan Karel vydal na univerzitu do Prahy, studoval i se svým mladším bratrem „humaniora“ u jezuitů ve Święciechowé (1642-1652). Během sedmi let, která strávil na studiích na pražské univerzitě, získal titul bakaláře na filozofické fakultě (13. června 1652), bakaláře teologie 204 a licenciát z práva. Duchovní svěcení přijal v Praze v roce 1661, po návratu působil dva roky jako kaplan ve Świebodzině a násled-

\footnotetext{
194 K. BerÁneK (ed.), Magistri, baccalaueri, s. 63.

195 AUK, f. Matriky, M 12, fol. 88r.

196 NK ČR, Th. 495.

197 A. BonIECKI, Herbarz Polski, XIII, Warszawa 1909, s. 229-231; S. UrusKi, Rodzina. Herbarz szlachty polskiej, VIII, Warszawa 1911, s. 224; K. NiEsIECKI, Herbarz Polski, V, Lipsk 1840, s. 458.

198 Jan Wiśniewski, Katalog prałatów i kanoników sandomierskich od 1186-1926 roku tudzież sesje kapituły sandomierskiej od 1581 do 1866 roku, Radom 1926.

199 K. NiesieCKi, Herbarz Polski, VIII, s. 599-601.

200 AUK, f. Matriky, M 6, p. 351-354, 363-364; AUK, f. ÚT KFU, V (1705-1710), p. 81, 101.

201 Antoni Gąsiorowski (ed.), Urzędnicy centralni i nadworni Polski XIV-XVIII wieku. Spisy, Kórnik 1992, s. 148.

202 K. BERÁNEK (ed.), Magistri, baccalaueri, s. 275.

203 T. ŻychlińsKi, Zlota księga szlachty polskiej, I, Poznań 1879, s. 348-349; Rody szlacheckie w Wielkopolsce w XVI-XIX w. (ułożone alfabetycznie wedtug nazwisk), Z, AWJS, rkp. 1689, Biblioteka PTPN, s. 20.

${ }^{204}$ K. BERÁNeK (ed.), Acta facultatis philosophicae, s. 127-128.
} 
ně pět let jako probošt farnosti v Hlohově. V letech 1685 a 1687 byl rektorem jezuitské kongregace v Hlohově a děkanem hlohovským. Během své kněžské služby se vždy staral o potřeby církve, mimo jiné dokončil obnovu farního kostela zničeného Švédy v roce 1642. Díky jeho péči a finančním prostředkům se podařilo svatyni zvětšit a vyzdobit její interiér. Jako horlivý duchovní pastýř dosáhl zvýšení počtu katolíků v rámci své farnosti. Silné duchovní založení je viditelné také v jeho poslední vůli, která byla pořízena 6. srpna 1692. Značné peněžní částky věnoval na Kř́žovou a Loretánskou kapli v hlohovské katedrále (100 tolarů), na lampy v těchto kaplích (100 tolarů) a věčné světlo (150 tolarů). Aby se ujistil, že během mariánských slavností a nešpor bude litanie vykonána i s hudbou, věnoval na ty účely 300 tolarů a dalších 600 tolarů ustanovil jako odkaz chudým, jimž mělo být v katedrále a v kostele každou neděli rozdáváno po 12 groších. ${ }^{205}$ Celkově jej tedy charakterizovalo nejen skvělé vzdělání, ale také postoje hodné duchovního pastýře. Na jeho príkladě, podobně jako u jeho mladšího bratra a Jana Krauseho, lze pěkně sledovat príistup polského měštanstva 17. století ke vzdělání a společenským závazkủm.

O pět let mladší Martin Ignác Zahn také získal dobré vzdělání a dal se na kněžskou dráhu. Během studia v Praze mu byl v roce 1655 udělen titul bakaláře na filozofické fakultě a hned v následujícím roce titul mistra. Stal se také posluchačem teologické fakulty. ${ }^{206}$ Podobně jako jeho bratr přijal kněžské svěcení v Praze, byt’ o rok dříve. Rok přisluhoval jako kaplan v Hlohově, poté byl až do roku 1681 proboštem ve vsi Chróścina ve Slezsku. Od 14. srpna 1681 pak sloužil jako probošt v Żukowicích a zároveň se staral o katedrální pěvecký sbor v Hlohově. Kromě toho byl oltářníkem v jedné z kaplí hlohovské katedrály a správcem kostela v Sokolnikách. ${ }^{207}$

Bratři Zahnovi bydleli během svých studií v Praze s již zmiňovaným Janem Krausem, který společně s nimi studoval na filozofické fakultě. Jeho vzdělání bylo z celé trojice nejslabší, byt' jinak zcela dostatečné, protože byl v roce 1658 tamtéž promován bakalářem a v následujícím roce mistrem. ${ }^{208} \mathrm{~V}$ roce 1660 byl, podobně jako mladší z bratř́ Zahnů, vysvěcen na kaplana a od roku 1664 sloužil jako probošt v Żukowicích ve Slezsku. Jeho kariéru oproti bratř́m Zahnovým asi nelze považovat za př́liš úspěšnou. Během vizitace $\mathrm{v}$ roce 1679 bylo zjištěno, že kostel pod jeho správou sice vypadá celkem dobře, ale jen velmi málo osob se zúčastňuje bohoslužeb, protože celá ves propadla protestantské herezi. ${ }^{209}$ Církevní kariéry bratř̌i Zahnových a Jana Krauseho byly spojeny s hlavním tehdejším cílem hlohovských jezuitů, jímž byla rekatolizace na území hlohovského knížectví, kde dosud převládal protestantismus.

Vedle trojice výše zmíněných studentů ze Święciechowé je třeba zmínit ještě další trojici jejich krajanů: bratry Jindřicha Františka a Jana Aloise Güntery a Řehoře Fridricha Hoffmana. Jejich osudy nejsou tak dobře zpracovány, ale mají jeden společný prvek: pocházeli z rodin ševcovských cechovních mistrů. ${ }^{210}$ Navzdory původu tedy nebyli určeni k převzetí

\footnotetext{
205 Johannes Schulz, Zur Geschichte von Schwetzkau, einer Klosterstadt im Fraustädter Land, Köln - Wien 1971, s. $95,109$.

${ }^{206}$ K. BerÁneK (ed.), Magistri, baccalaueri, s. 274; AUK, f. Matriky, M 22, p. 16-17, 27-28; AUK, f. ÚT KFU, I (1624-1690, 1650-1690), p. 11; K. BERÁNEK (ed.), Acta facultatis philosophicae, s. 145-147.

207 J. Schulz, Zur Geschichte von Schwetzkau, s. 109.

${ }_{208}$ AUK, f. Matriky, M 22, p. 39-41, 50-51; AUK, f. ÚT KFU, I (1624-1690, 1650-1690), p. 15, 18.

209 J. Schulz, Zur Geschichte von Schwetzkau, s. 109.

210 Odwart Winterfeld, Die Einwohner der Stadt Schwetzkau 1636-1945, Ostdeutsche Familienkunde 10, 1962, s. 34-35.
} 
rodinného řemesla, ale bylo rozhodnuto umožnit jim vzdělání, jehož prostřednictvím měli dosáhnout společenského vzestupu. Není bohužel známo, nakolik byli ve své další kariére úspěšní, ale přinejmenším nepromarnili svůj pobyt v Praze. Jindřich se stal v roce 1652 bakalářem na filozofické fakultě, ${ }^{211}$ jeho bratr získal stejný titul v roce $1658 .{ }^{212}$ Řehoř Hoffman se stal bakalářem $v$ roce 1643 a mistrem o rok později. ${ }^{213}$ Je zřejmé, že i některé řemeslnické rodiny se aktivně snažily o společenský vzestup svých členů prostřednictvím vyššího vzdělání.

Vedle těch, kteří se uplatnili ve sféře administrativně-politické a církevní, tvořili další skupinu absolventů pražské univerzity literáti. Dnes bychom řekli: představitelé svobodných povolání. Jedním z nich byl Jan Auxenty Owaniszowic, šlechtic arménského původu ze Zamośće. ${ }^{214} \mathrm{~V}$ roce 1673 se mu podařilo získat titul bakaláře filozofie pražské univerzity a o rok později titul mistra. ${ }^{215}$ Je zajímavé, že tím své vzdělání neukončil, protože se v akademickém roce 1676/1677 zapsal ještě na Akademii v Zamośći. ${ }^{216}$ Jak již bylo zmíněno, realizoval se na poli literatury, hlavně psaním latinských epigramat. V roce 1700 vydal ve svém rodném městě sbírku těch epigramat, která považoval za nejzdařilejší. Kompilace nesla název Palmaris fructus variis epigrammatibus euriosis et politicis adornatus, commodo et usui nobilissimae studiosae juventutis ex Latino in patrium idioma transportatus" ${ }^{.217}$ Obecně bylo jeho dílo považováno „za zbyt wolne i obok pięknych epigramatów łacińskich nic nie znaczace" (př́iliš prosté a vedle pěkných latinských epigramat nic neznamenající), ačkoli byla zdůrazňována jeho schopnost vybrat ze svých děl ta nejpovedenější. ${ }^{218}$

Dalším absolventem s literárními schopnostmi byl vedle Owaniszowice Vojtěch Kłosowicz, původem ze šlechtické rodiny užívající erbu Kłosy. ${ }^{219}$ Než se začal věnovat literární tvorbě, dal se na pedagogickou a církevní dráhu. Nejprve od roku 1725 přednášel filozofii ve Węgrowě jako člen společenstva kněží ,in commune viventium“, nazývaných v Rzeczypospolité (podobně jako v Čechách) bartolomité (bartolomici, bartoszkowie), podle zakladatele Bartoloměje Holzhausera (1613-1658). ${ }^{220}$ Následně studoval na teologických a právnických fakultách v Itálii a Francii. V roce 1732 byl zapsán jako student právnické fakulty pražské univerzity. ${ }^{221}$ Během pobytu v Ř́mě se setkal s Josefem Ondřejem Załuským, pozdějším biskupem kyjevským, který Kłosowicze doporučil svým pařížským známým (Jeanu Consturierovi, generálnímu představenému semináře svatého Sulpicia, a Françoisi Salmonovi, doktoru teologie a knihovníkovi Sorbonny). Díky těmto svazkům se Kłosowicz v roce 1734 setkal s francouzskou královnou Marií Leszczyńskou. Po návratu domů se stal v roce 1738 kanovníkem brzeským a proboštem mielczyckým

\footnotetext{
${ }^{211}$ K. BerÁneK (ed.), Acta facultatis philosophicae, s. 127-129; TÝŽ (ed.), Magistri, baccalaueri, s. 92.

212 AUK, f. Matriky, M 22, p. 39-41; AUK, f. ÚT KFU, I (1624-1690, 1650-1690), p. 15.

${ }^{213}$ K. BerÁneK (ed.), Acta facultatis philosophicae, s. 58-59, 75-76; TÝž (ed.), Magistri, baccalaueri, s. 106.

${ }^{214}$ L. Korwin, Ormiańskie rody szlacheckie, s. 139.

215 AUK, f. Matriky, M 22, p. 139-140, 146, 148; AUK, f. ÚT KFU, bez č. (1673-1690), p. 64.

${ }^{216}$ H. GMiterek (ed.), Album studentów Akademii Zamojskiej, s. 271.

217 Sadok Baracz, Żywoty sławnych Ormian w Polsce, Lwów 1856, s. 256.

218 Hieronim JuszYŃski, Dykcyonasz poetów polskich, II, Kraków 1820, s. 32.

219 A. BonIECKI, Herbarz Polski, X, Warszawa 1907, s. 186; S. URUSKI, Rodzina. Herbarz szlachty polskiej, VII, Warszawa 1910, s. 28.

${ }^{220}$ Arkadiusz KoєоDZIEıczyк, Z dziejów węgrowskiej szkoły księży komunistów 1711-1833, Szkice Podlaskie 5, 1996, s. 29.

221 AUK, f. Matriky, M 12, fol. 46r.
} 
a wołczyńským;222 od roku 1751 byl také kanovníkem varšavským. Literární dílo, psané výrazným barokním stylem, se do dnešní doby dochovalo jen z menší části. 223 Je známo, že byl překladatelem Instrukcji względem pryncypalniejszych punktów religii, vydané v Supraślu v letech 1750 a 1758.224 Obecně byl člověkem dobře vzdělaným, a jak vyplývá z jeho korespondence se Załuským, ovládal přinejmenším tři jazyky, takže se v soudobém literárním světě mohl pohybovat se značnou lehkostí.

Vojtěch Kłosowicz je posledním ze studentů pražské univerzity, jehož osobu lze v této práci sledovat na základě širšího spektra pramenů a literatury. Jistě by bylo možné něco zjistit také o dalších osobách, ale narážíme zde na komplikovanou heuristiku, která by vyžadovala pramenný výzkum v knihovnách a archivech po celém Polsku. Tito bývalí studenti pražské univerzity se bud' do politického a kulturního života Rzeczypospolité nijak nezapsali, nebo jejich osudy nejsou z dosavadní literatury známy a teprve čekají na objevení. U několika studentů lze jejich osudy mimo pražskou univerzitu alespoň naznačit. Kryštof Zianowski, student právnické fakulty z roku 1686, byl mimo jiné notářem v Radomi. ${ }^{225}$ Jan Kazimír Schauer de Augenburg, bakalář právnické fakulty z roku 1672,226 byl synem Jana Jiř́iho Schauera (Szawra), zkušeného právníka z ingolštadské univerzity, kterého Kazimír Lev Sapieha povolal na nově ustavenou katedru civilního práva vilenské akademie. ${ }^{227}$ Martin Alexius Fengler nejenže se stal bakalářem (1697) a mistrem (1697) na pražské filozofické fakultě, ale také bakalářem teologie (1699) na fakultě teologické. ${ }^{228}$ Samotný původ a studijní výsledky některých osob tedy napovídají, že musely sehrát alespoň malou dějinnou roli. Kvůli torzovitosti pramenů se v předkládané studii zcela určitě neobjevili všichni polští studenti šlechtického i měštanského původu, kteří prošli posluchárnami pražského Karolina a Klementina. Navazující heuristika, která rozšîrí okruh využitých pramenů na archiválie uložené v jiných institucích, představuje úkol pro další výzkum v budoucnosti.

\section{Závěr}

Podrobná analýza pramenného materiálu, zejména matrik a alb studentů, umožnila přesně identifikovat sto jménem známých osob z Rzeczypospolité, které studovaly na čtyřech fakultách pražské univerzity v 17. a 18. století. K tomuto počtu lze připojit ještě devatenáct studentů z let 1600-1624, které nalezl Henryk Barycz během svého pobytu v Praze v roce 1936, neuvedl však jejich jména a omezil se na konstatování, že byli „w większości mieszczańskiego pochodzenia“229 (většinou měštanského původu). $\mathrm{Z}$ toho důvodu a také

\footnotetext{
222 Bogumił Stanisław KuPŚć - Krystyna MuszyńsKa (edd.), Korespondencja Józefa Andrzeja Załuskiego 17241736, Wrocław - Warszawa - Kraków 1967, s. 164-165, 170, 657.

${ }^{223}$ Marian Brudzisz, Nauczanie teologii w Instytucie Księży Komunistów, in: Marian Rechowicz (ed.), Dzieje teologii katolickiej w Polsce, II/2, Lublin 1975, s. 192-194.

${ }^{224}$ Karol Estreicher, Bibliografia polska, 19: stólecie XV-XVIII, Kraków 1903, s. 311-313.

225 AUK, f. Matriky, M 6, fol. 100v.

226 AUK, f. Matriky, M 22 , p. 123-125.

227 M. BALIŃski, Dawna Akademia Wileńska, s. 147-148; K. ČEPIENÉ - I. Petrauskiené (edd.), Vilniaus Akademijos, s. 95-96; K. Estreicher, Bibliografia Polska, 22, stólecie XV-XVIII, Kraków 1908, s. 186.

228 AUK, f. Matriky, M 22, p. 274-276; AUK, f. ÚT KFU, III (1697-1701), p. 11.

${ }^{29}$ H. BARYCZ, Dziejowe zwiazki Polski, s. 34.
} 
proto, že studovali vesměs ještě před rokem 1623, tedy před sloučením starého Karlova učení s jezuitskou akademií (Klementinum), byli vzati v potaz jen pro statistické účely. Z kontextu Baryczovy práce se zdá, že se pravděpodobně jednalo spíše o posluchače druhé z uvedených institucí. Ani za pomoci moderní edice alba pražské jezuitské akademie ${ }^{230}$ nemůžeme přesně zrekonstruovat, jaké osoby měl historik na mysli. V každém případě se během dvou století vydalo za vyšším vzděláním na pražskou univerzitu celkem zhruba 120 mladých mužů z Rzeczypospolité. Není to samozřejmě plný počet těch, kteří na pražském vysokém učení studovali - kompletní údaje nelze zrekonstruovat, nebot' část materiálu není dochována, nebo jsou údaje v archiváliích nejasné (např. v případě pramenů týkajících se Ludvíka Wielopolského a bratř́i Radziwiłło̊). Můžeme jen litovat, že H. Barycz při zkoumání dnes již nedostupných dokumentů nezveřejnil výsledek své rešerše v úplnosti.

Pohlédneme-li na výše uvedené výsledky předkládané práce v širším, celoevropském kontextu akademické peregrinace mládeže z Rzeczypospolité ve vztahu k zahraničním univerzitám, musíme konstatovat, že v porovnání s množstvím studentů, kteří se vydali za vzděláním na univerzity v západní Evropě, se v případě Prahy jedná o počty značně nízké, ba přímo marginální. ${ }^{231}$ Zároveň je ale třeba připomenout, že pražská univerzita spojená s jezuitským řádem byla katolickou vysokou školou, v zásadě uzavřenou pro studenty jiného vyznání. 232

Důvody pro rozhodnutí o zahájení studia na pražské univerzitě mohly být různé, hlavní roli ale hrály finanční možnosti studentů a jejich rodin. Pokud měl mladý šlechtic nebo měšt’an dostatek prostředků pro mnohaleté a nákladné studium ve vzdálených akademických centrech, využil této příležitosti a na blízké vysoké školy se neohlížel. Plyne z toho, že Prahu navštěvovali hlavně studenti pocházející až na výjimky (Wiśniowiecki, Szembek, Szaniawski, Lanckoroński, Zakrzewski, Grądzki, Kuropatnicki) z méně zámožných šlechtických rodin Rzeczypospolité, což se týká i studentů měšt’anského původu (např́klad bratř́i Zahnů, Günterů nebo Rehoře Hoffmana).

Druhým závažným aspektem, byt’ na první pohled banálním, byla vzdálenost Prahy od bydliště studenta. Svědčí o tom skutečnost, že z Velkopolska pocházelo na tři desítky studentů, z toho čtrnáct z nevelkého městečka Święciechowa (2200 obyvatel v letech 17061710),233 ležícího na samé hranici Rzeczypospolité s habsburskou monarchií a vzdálené od Prahy vzdušnou čarou jen 300 kilometrů. Čím dále na východ, tím je počet studentů menší: z Litvy nebo Rusi to byla pouze hrstka mladíků (11), a to především zámožnějších osob šlechtického původu (Szaniawski, Baranowski, Juchnowicz). Výjimku v tomto ohledu

\footnotetext{
${ }^{230}$ M. Truc (ed.), Album Academiae Pragensis.

${ }^{231}$ Pro srovnání lze uvést počty studentů z Rzeczypospolité na některých západoevropských univerzitách: Lipsko - 1128 (v letech 1601-1772), Wittenberg - 749 (1601-1772), Jena - 564 (1601-1772), Halle - 251 (1690-1730), Frankfurt - 1107 (1601-1772), Rostock - 381 (1601-1772), Heidelberg - 211 (1601-1690), Vídeň - 164 (1601-1690), Ingolstadt - 477 (1601-1700), Leyden - 1143 (1579-1772), Basilej - 224 (16011755), podle: M. PAWLaK, Studia uniwersyteckie, př́lohy č. 8-13, 15, 22, 24, 25, 28.

232 Vyskytly se př́pady protestantských mladíků z Rzeczypospolité, kteří studovali na katolických univerzitách, srov. M. Chachaj, Protestanci polscy. Byly to ale spíše výjimečné príípady. M. Chachaj se navíc zabýval situací na vybraných italských, francouzských a německých univerzitách, není proto možné vztáhnout jeho závěry na pražskou univerzitu, která se nacházela uprostřed katolických enkláv habsburské monarchie. Kromě toho je nepravděpodobné, že by se jezuité neřídili ustanoveními buly Pia IV. z roku 1564 ukládající závazek katolické víry promovendům na katolických univerzitách, což lze vztáhnout i na samotnou formu imatrikulace.

233 O. Winterfeld, Die Einwohner, s. 33.
} 
představují studenti z Prus, pro něž ale vzhledem k četným měšt’anským stipendiím a obecně větší mobilitě nebyla vzdálenost tak rozhodující okolností.

Finanční možnosti jsou tedy spolu s geopolitickými podmínkami hlavním klíčem k pochopení důvodů, proč si studenti z Rzeczypospolité vybírali pro svá vyšší studia Prahu. Určitě se neřídili prestiží školy (dávný lesk zdejšího studium generale byl minulostí) ani osobnostmi profesorů, nebot' i v domácích akademických centrech bylo možné se setkat s podobně vzdělanými pedagogy. Tato stránka působila spíše v neprospěch pražské univerzity ve srovnání s přitažlivostí západoevropských vysokých škol. Můžeme tedy ř́íci, že studenti z Rzeczypospolité, kteří se v 17. a 18. století vydali do Prahy, tak učinili především na základě důvodů finančních a geografických. V poměru $\mathrm{k}$ nižším nákladům na cestu a ubytování tak nepř́liiš vzdálená Praha skýtala slušné možnosti pro získání vyššího vzdělání.

Motivace jednotlivých studentů se samožrejmě mohly různit a zahrnovat řadu dílčích, navzájem propojených a v pramenech nepostižitelných aspektů. $V$ úvahu je třeba vzít také ohledy na rodinu a tradici, protože mezi studujícími nacházíme po dvou představitelích z osmi rodin (Briskorn, Fengler, Günter, Zahn, Zakrzewski, Kern, Kretzmer, Skorzewski), kteří nestudovali $\mathrm{v}$ těch samých letech. Je tedy pravděpodobné, že pro mladšího z př́islušníků téže rodiny mohla být vybrána již „osvědčená“ univerzita. Nejlépe je to vidět na uvedeném př́íkladu studentů ze Święciechové. ${ }^{234}$ Oproti tomu důvody, proč se na pražskou univerzitu vydali Michal Korybut Wiśniowiecki, ${ }^{235}$ Jeroným Roth nebo Kryštof Antonín Szembek, byly odlišné.

Důležitou součástí výzkumu studia mládeže z Rzeczypospolité je také otázka, nakolik rozhodnutí zahájit a zdárně dokončit studium v Praze ovlivnilo další životní osudy studentů, respektive nakolik se pro ně znalosti a akademické grady získané na pražské univerzitě ukázaly jako užitečné. Řešení této otázky je komplikované vzhledem k poměrně velkému množství zkoumaných osob a nedostatku údajů o většině z nich. Charakter společenského zřízení polského státu, sociální gradace a z ní vyplývající favorizování privilegované skupiny - šlechty - rovněž znemožňuje nalezení jednoznačné odpovědi.

Mnoho absolventů pražského vysokého učení, zvláště těch šlechtického původu, úspěšně získalo výnosné funkce zemských úřredníků, výjimečně se jim dokonce mohlo dostat té cti, že usedli na královský trůn nebo arcibiskupský stolec. Jejich pozdější společenské postavení spíše nebylo závislé na tom, jak byli výmluvní, vzdělaní nebo intelektuálně zdatní. Hlavní roli tu zjevně hrály jiné okolnosti, jako postavení a finanční situace rodiny, konexe a celková oblíbenost $\mathrm{v}$ rámci šlechtických vrstev. Během volby Michala Korybuta králem mohla jen těžko sehrát nějakou roli skutečnost, že v mládí studoval v Praze, stejně jako je málo pravděpodobné, že rychlou a zářnou kariéru Kryštofa Antonína Szembeka výrazněji ovlivnil „pražský faktor“. Bylo by možné uvést řadu př́ikladů absolventů, kteří po návratu do země získali úřady, hodnosti nebo v př́padě duchovních prebendy, ačkoli si z pražských studií nepřivezli akademický titul (byt' $\mathrm{k}$ tomu, aby se student filozofické fakulty stál bakalářem, stačily dva roky). Přesto jim to nebylo na překážku v budoucí úřední, politické či duchovní kariéře (Ondřej a Ignác Zakrzewští, Mikołaj Lanckoroński, Martin Motowski). Tento model je samozřejmě typický v případě studentů šlechtického původu, prričemž nopak řada z nich také úspěšně zakončila pražská studia promocí na bakaláře nebo mistra filozofie.

${ }^{234}$ R. T. TомсZак, Studenci ze Święciechowy, s. 122-124.

235 TÝž, Wychowanie $i$ wykształcenie. 
Nedá se ale jednoznačně určit, zda mělo získané vzdělání vliv na jejich pozdější hodnosti či úřady, a to tím spíše, že některé $\mathrm{z}$ nich se dědily v rámci jedné rodiny.

O tom, nakolik byly pražské akademické tituly užitečné pro další kariéru, svědčí pouze príklady absolventů měštanského původu, protože jejich společenské postavení záleželo mnohem více na vlastních ambicích a tvrdé práci. Vezmeme-li si jako príklad trojici studentů ze Święciechové (bratři Zahnovi a Jan Krause), je možné s jistotou konstatovat, že vzdělání získané na pražské univerzitě se stalo rozhodujícím činitelem pro jejich další kariéru, $\mathrm{v}$ tomto př́padě v oblasti církevní správy. Neměli bychom také zapomínat, že to, co se studenti z Rzeczypospolité v Praze naučili, je určitým způsobem formovalo a zůstalo $v$ jejich paměti po dlouhá léta. Vědomosti a zkušenosti nabyté v mládí mohou člověka ovlivňovat až do konce jeho života a u části studentů z Rzeczypospolité se v př́padě pražských studií jednalo o jediné setkání s vy̌̌ším vzděláním za celý jejich život. 


\section{Příloha}

\section{Seznam studentů z Rzeczypospolité na pražské univerzitě v 17. a 18. století}

Jan Aleksander Baranowski - student pocházející z obce Piętkowo na Podlesí. Používal erb Grzymała. Titul bakaláře získal na filozofické fakultě 8. června 1690. Dne 3. června 1693 byl jmenován litevským podčeším a tento úruad zastával do 22. února 1704. Zemřel 31. května 1706. Podrobněji o něm srov. s. 77.

Jan Bialski - student šlechtického původu. Studoval logiku na filozofické fakultě ve školním roce 1647/1648, ale byl povolán zpátky do Polska z důvodu obléhání Prahy Švédy.

Andrzej Wojciech Bogacz - pocházel z obce Święciechowa. Titul bakaláře získal na filozofické fakultě 18 . května 1643, titul mistra 25. srpna 1648. Během první části svého studia byl ubytován v semináři sv. Václava.

Andrzej Borzysławski - student šlechtického původu, erbu Szreniawa. Jeho rodina pocházela z Miłkowic v sieradzkém okrese, ale již na konci 16. století se usadila na dnešní Ukrajině. Titul bakaláře filozofické fakulty získal 10. května 1703. Během svého studia byl ubytován v konviktu sv. Bartoloměje.

Jan Kazimierz Braun - student polského původu (Polonus). Roku 1686 je uveden jako student právnické fakulty.

Jakub Jan Briskorn - student pruského původu z Reszelu (Rößel). V roce 1692 získal titul bakaláře na filozofické fakultě, 12. srpna 1693 pak titul mistra. V roce 1694 byl zapsán na právnické fakultě.

Jakub Jan Briskorn - student pruského původu z Reszelu (Rößel). V roce 1731 je uveden jako student právnické fakulty. Nejspíše vnuk Jakuba Jana Briskorna, studenta filozofické a právnické fakulty z let 1692-1694.

Franciszek Antoni Brzeski - student šlechtického původu. V roce 1703 je uveden jako student právnické fakulty.

Piotr Pawel Brzeźiński - student šlechtického původu erbu Łabędź z rawského vojvodství. V roce 1692 je uveden jako student právnické fakulty.

Jan Stanisław Cetner - student šlechtického původu erbu Przerowa. Pocházel ze slezské šlechtické rodiny užívající predikát z Czertwic. V roce 1714 je uveden jako student právnické fakulty. Jeho otcem byl Aleksander Cetner, kastelán bracławský. V roce 1717 vstoupil do řádu františkánů. 
Stanisław Ciświcki - student šlechtického původu erbu Wieniawa ze Zbąszyna. V roce 1692 je uveden jako student právnické fakulty. Syn Ludwika Ciśwického, starosty stawiszyńského a Zofie Oleśnické.

Sebastian Cupietius - student pocházející z Częstochové. Titul bakaláře získal na filozofické fakultě 6. července 1667.

Jan Ignacy Czechowicz (Czechowitz) - v roce 1686 je uveden jako student právnické fakulty.

Antoni Jan Czermińsky - student šlechtického původu erbu Wieniawa. V roce 1686 je uveden jako student právnické fakulty.

Protazy Dobrzyński - student šlechtického původu erbu Jelita. Člen řádu cyriaků. V akademickém roce 1642/1643 studoval logiku na filozofické fakultě.

Piotr Jan Doge - student pocházející z města Czaplinek (Tempelburg). Titul bakaláře získal na filozofické fakultě 11 . června 1675, titul mistra 25. srpna 1676.

Grzegorz Dziurkowicz - student neznámého původu. Titul bakaláře získal na filozofické fakultě 26. května 1727, titul mistra 22. července 1728.

Kacper Kazimierz Felski - student pruského původu z Gdaňska. Je uveden v seznamu studentů gdaňského gymnázia v roce 1649. Titul bakaláře získal na filozofické fakultě 23. června 1655.

Kacper Józef Fengler - student pocházející z obce Święciechowa. Studoval na právnické a filozofické fakultě. Titul bakaláře získal na filozofické fakultě 27 . června 1682 extra ordinem, protože již 3. srpna 1682 měl na téže fakultě mistrovskou promoci.

Marcin Aleksy Fengler - student pocházející z obce Święciechowa; pravděpodobně mladší bratr výše uvedeného Kacpera Józefa Fenglera, student filozofické a teologické fakulty. Titul bakaláře získal na filozofické fakultě 23. května 1697, titul mistra pak extra ordinem 18. července 1697. Titul bakaláře teologické fakulty získal 27. srpna 1699. Během celé doby studií byl ubytován v konviktu sv. Bartoloměje.

Franciszek Polikarp Filipowicz - student šlechtického původu z Litvy. Představitel na Litvě a v Bělorusku rozvětvené rodiny erbu Pabóg. Titul mistra získal na filozofické fakultě 27. června 1681. Během studií byl ubytován v konviktu sv. Bartoloměje.

Jan Wojciech Fryderyk - student pruského původu z města Braniewo. Titul mistra získal na filozofické fakultě 5. srpna 1660. Během studií byl ubytován v konviktu sv. Bartoloměje.

Jakub German - student pruského původu z města Braniewo. Titul bakaláře filozofické fakulty získal 14. června 1683, titul mistra 21. srpna 1684. 
Jan Goliński - student šlechtického původu. Je uveden jako student filozofické fakulty v akademickém roce 1647/1648. Opustil Prahu, aby se zúčastnil tažení proti Tatarům.

Tomasz z Kubry Grądzki - student šlechtického původu. Pocházel ze staré a rozvětvené šlechtické rodiny erbu Łada, usazené v Mazovsku. Titul mistra získal na filozofické fakultě 30. srpna 1661. Podrobněji o něm srov. s. 77.

Marcin Wojciech Grzegorz - v roce 1668 je uveden jako student právnické fakulty.

Henryk Franciszek Günter - student pocházející z obce Święciechowa. Titul bakaláre získal na filozofické fakultě 13. května 1652. Jeho otcem byl pravděpodobně Grzegorz Günter, ševcovský mistr.

Jan Alojzy Günter - student pocházející z obce Święciechowa. Nejspíše byl mladším bratrem výše uvedeného Henryka Franciszka Güntera a druhým synem ševcovského mistra Gregorze Güntera. Titul bakaláře získal na filozofické fakultě 26. dubna 1658.

Jan Wojciech Güttla (Guettla) - student pocházející z města Wschowa (Fraustadt). Titul bakaláře filozofické fakulty získal 9. května 1699. K 6. listopadu 1671 je uveden také jako student lékařské fakulty.

Andrzej Hasslauer - student pruského původu z města Dobre Miasto (Guttstadt). $\mathrm{K}$ roku 1690 je uveden jako student právnické fakulty.

Abraham Hertzberg - student pruského původu z Gdaňska, narozený v roce 1619. $\mathrm{V}$ roce 1631 je uveden $\mathrm{v}$ seznamu studentů gdaňského gymnázia. Titul mistra získal na filozofické fakultě 5. srpna 1641, byl také studentem teologické fakulty. Později studoval na univerzitě v Leydenu.

Grzegorz Fryderyk Hoffman - student pocházející z obce Święciechowa, z rodiny ševce. Titul bakaláře získal na filozofické fakultě 18. května 1643 na základě filozofické rozpravy, která byla během promoce pozitivně oceněna. Titul mistra získal 25. srpna 1644.

Andrzej Jahling - student pruského původu z Elbinku. Studoval také na univerzitě v Královci (v letním semestru 1650). Titul bakaláře získal na filozofické fakultě 23. června 1655.

Stefan Jakubowski - student pocházející z Częstochowé. Titul bakaláře získal na filozofické fakulě 11. června 1673.

Abraham Jansen - student pruského původu z Gdaňska. V roce 1659 byl zapsán na právnické fakultě.

Franciszek Jordan - student neznámého původu. V roce 1659 byl zapsán na právnické fakultě. 
Andrzej Kazimierz Juchnowicz - student šlechtického původu ze Žmudi z obce Szymonwice. Představitel litevské větve rodu Juchnowiczů erbu Leliwa. Titul bakaláře získal na filozofické fakultě 8 . června 1660.

Karol Ferdynand Kern - student pocházející z Mazovska (Varšava). Zároveň s otcem Janem byl v roce 1665 zapsán jako student právnické fakulty.

Jan Kern - student pocházející z Mazovska (Varšava). Zároveň se synem Karlem Ferdinandem byl v roce 1665 zapsán jako student právnické fakulty.

Benedykt Wojciech Klein - student pruského původu z města Pieniężno (Mehlsack). Titul bakaláře získal na filozofické fakultě 18. července 1663. K datu 18. srpna 1664 je zmiňován jako student, který nezískal titul mistra.

Wojciech Kłosowicz - student šlechtického původu erbu Kłosy. V roce 1725 přednášel filozofii ve Węgrowie, poté studoval na teologických a právnických fakultách v Itálii a Francii. V roce 1732 je uveden jako student právnické fakulty pražské univerzity. Podrobněji o něm srov. s. 81-82.

Mateusz Kintzell - student pocházející z obce Święciechowa. Titul bakaláře získal na filozofické fakultě 19. května 1665.

Krysztof Koffliski - student pocházející z poznaňského vojvodství. Titul bakaláře získal na filozofické fakultě 11 . května 1705 , titul mistra 5 . srpna 1706 . Během celé doby studií byl ubytován v semináŕi sv. Václava.

Wawrzyniec Kolakowski - student šlechtického původu z Ciechanowa užívající erb Kościesza. Nejspíše pocházel z tzv. „Starych Kołaków“, tedy z nejstarší větve rodiny Kołakowských, jejiž rodokmen sahal až k počátku 15. století. Titul bakaláře získal na filozofické fakultě 2 . května 1651, titul mistra 19. srpna 1652.

Dominik Mikołaj Königsman - student šlechtického původu z města Reszel (Rößel). Titul bakaláře získal na filozofické fakultě 22. května 1708.

Aleksander Kotudzki - student šlechtického původu. V roce 1686 je uveden jako student právnické fakulty.

Szymon Koziol - student pruského původu. Titul bakaláře získal na filozofické fakultě 13. srpna 1671, titul mistra 16. srpna 1672 . V době studia byl ubytován v konviktu sv. Bartoloměje.

Jan Krause - student pocházející z obce Święciechowa. Titul bakaláře získal na filozofické fakultě 29 . dubna 1658 , titul mistra 18. srpna 1659 . Po získání titulu bakaláře byl ubytován v konviktu sv. Bartoloměje. Podrobněji o něm srov. s. 79-80 
Wawrzyniec Kretzmer - student pruského původu z města Dobre Miasto (Guttstadt). Titul bakaláře získal na filozofické fakultě 28. května 1668, titul mistra 5. září 1669. S velkou pravděpodobností byl jeho bratrem Michał Antoni Kretzmer.

Michal Antoni Kretzmer - student pruského původu z města Dobre Miasto (Guttstadt); přináležel ke šlechtickému stavu. Titul bakaláře získal na filozofické fakultě 9 . května 1669 , titul mistra 27. srpna 1670. S velkou pravděpodobností byl jeho bratrem Wawrzyniec Kretzmer.

Ambroży Kryplowicz - student pocházející z obce Święciechowa. Titul bakaláře získal na filozofické fakultě 22. května 1656, titul mistra 13. srpna 1657.

Bonawentura Marcin Krüger - narodil se v Leszně. S velmi dobrými výsledky, zvláště v chirurgii, studoval na lékařské fakultě (1714); působil jako vojenský chirurg.

Marcin Kulczycki - student šlechtického původu z karpatského podhůří na území dnešní Ukrajiny, okres Sambor lvovské oblasti. Představitel rodu silně rozvětveného na Červené Rusi, užívajícího erbu Sas. Titul bakaláře získal na filozofické fakultě 13. června 1674, titul mistra 26. července 1674 (oba extra ordinem). Uveden jako student teologické fakulty. V době studií byl ubytován v konviktu sv. Bartoloměje.

Andrzej Kazimierz Waclaw Kuropatnicki - student šlechtického původu užívající erb Nieczuja, z rodu osedlého v okolí Lvova. Syn Hieronyma, kastelána kyjevského a Joanny Sokolnické, dcery korouhevníka lvovského. Titul doktora filozofie získal na pražské filozofické fakultě v roce 1682. Podrobněji o něm srov. s. 79.

Mikołaj z Brzezia Lanckoroński - syn Franciszka Stanisława, spolumajitele Jagielnice, a Heleny Chomętowské, dcery lovčího stężyckého. Student právnické fakulty (1653). Starosta skalský poté, co mu byl tento úrad postoupen strýcem Hieronymem, podkomořím podolským. Poslední mužský potomek starší (jelnické) větve rodu Lanckorońských z Brzezia erbu Zadora. Byl pohřben v Jagielnici 21. února 1706. Podrobněji o něm srov. s. 77-78.

Mateusz Laurentz - student filozofické fakulty, uváděný v letech 1647/1648 jako Polák studující logiku.

Aleksander Lawski - student šlechtického původu z Mazovska. Titul bakaláře filozofické fakulty získal 3. května 1645.

Józef Kazimierz Lewicki - student šlechtického původu z Lewiczyna na Mazovsku užívající erb Prawdzic. V roce 1658 je uveden jako student právnické fakulty.

Wojciech Tomasz Mazurkowicz - student pocházející z města Chrzanów. Titul bakaláře filozofické fakulty získal 23. června 1655, titul mistra 6. září 1656. 
Justus Leopold Milheini (Mölheim) - student pruského původu z Gdaňska. V roce 1669 uveden jako student lékařské fakulty. Titul mistra získal na filozofické fakultě extra ordinem 5. záŕí 1669.

Hiacynt Milkiewicz - student pocházející z města Żerków. Titul bakaláře získal na filozofické fakultě 18. května 1702, titul mistra 4. července 1703.

Marcin Motowski - student šlechtického původu z Podlesí. V roce 1747 je uveden jako student prvního ročníku lékařské fakulty. V roce 1754 se stal starostou jaźnienským na Vilensku.

Kazimierz Ignacy Nowacki - student pocházející z obce Niegowa. Titul bakaláře získal na filozofické fakultě 17 . května 1666, titul mistra 18. srpna 1667.

Marcin Olrich - student pocházející z obce Tuczna. V roce 1672 je uveden jako student právnické fakulty.

Jan Opaleński (Opaliński) - student pocházející ze známé velkopolské šlechtické rodiny z Bnina, užívající erbu Łodzia. V roce 1707 je uveden jako student právnické fakulty.

Jan Auxenty Owaniszowic - student pocházející z arménské šlechtické rodiny usedlé v Zamości. Titul bakaláře získal na filozofické fakultě 11. června 1673, titul mistra 26. července 1674. Poté studoval na Akademii v Zamości (1676/1677). Podrobněji o něm srov. s. 81 .

Jakub Pawłowicz - student pocházející z Velkopolska. V roce 1780 je uveden jako student prvního ročníku na lékařské fakultě.

Antoni Piotr Petäin - student pruského původu z Gdaňska. V roce 1722 je uveden jako student právnické fakulty.

Mateusz Kazimierz Płoński - student šlechtického původu z obce Płonki. Představitel nižšího šlechtického rodu usazeného na Podlesí a uživajícího erbu Prus I. Titul bakaláře získal na filozofické fakultě 15 . května 1657 , titul mistra následně 29. července 1657 . V době svého studia byl ubytován v semináři sv. Václava.

Pawel Pieszczoch - v roce 1690 je uveden jako student farmacie na lékařské fakultě.

Stefan Przespolewski - student šlechtického původu. Pocházel ze starého velkopolského rodu uživajícího erb Topór. V roce 1682 je uveden jako student právnické fakulty. Před rokem 1719 je také doložen jako dědic vsí Bieganin a Strzebowa. Účastnil se volby Augusta II. Silného za vojvodství kališské; působil také jako soudce kališský. Oženil se v Boguszyně 6. března $1696 \mathrm{~s}$ Ludwikou Jaraczewskou, s níž měl deset dětí (tř́i dcery a sedm synů). Podrobněji o něm srov. s. 77. 
Jan von der Pügsasau - student pruského původu z města Braniewo. Titul bakaláře získal na filozofické fakultě 12 . května 1659 . V době studií byl ubytován v konviktu sv. Bartoloměje.

Jan Roller - student pocházející z obce Święciechowa. V roce 1645 je zachycen jako student právnické fakulty.

Hieronym Roth - syn slavného vůdce pruské měštanské opozice Hieronyma Rotha a jeho ženy Barbary Fahrenheit, pocházel z Královce. Je uveden jako student pražské právnické fakulty v roce 1659. Později působil jako sekretář vojevody (1661) a krále (1669) Michala Korybuta Wiśniowieckého. Podrobněji o něm srov. s. 76.

Jan Kazimierz Schauer de Augenburg - student uvedený jako Litevec z Vilna; titul bakaláře získal na filozofické fakultě 28. srpna 1672. Byl synem Jana Jiř́ího Schauera, osvědčeného znalce práva z ingolštadtské akademie, kterého Kazimír Leon Sapieha povolal na nově vzniklou katedru civilního práva vilenské akademie.

Marcin Scheller - student pocházející z obce Święciechowa. K datu 18. srpna 1664 je uveden jako student, jemuž se nepodařilo získat titul mistra na filozofické fakultě pražské univerzity.

Jan Schnetla - student pruského původu z Olsztyna. V roce 1680 je uveden jako student právnické fakulty.

Krzysztof Skorzewski - student šlechtického původu z kališského vojvodství, z rodu uživajícího erbu Ogończyk. V roce 1693 je uveden jako student právnické fakulty. S největší pravděpodobností bratr Marcina Kazimierze Skorzewského.

Marcin Kazimierz Skorzewski - student šlechtického původu z kališského vojvodství, z rodu užívajícího erbu Ogończyk. V roce 1693 je uveden jako student právnické fakulty; s největší pravděpodobností bratr Krzysztofa Skorzewského.

Franciszek Teofil Sterllich - student šlechtického původu, psal se z Rakoniewic ve velkopolském vojvodství. V roce 1675 je uveden jako student právnické fakulty.

Bartłomiej Słupczyński - student zachycený v roce 1690 na právnické fakultě, měl hodnost probošta.

Marcjan Junosza Szaniawski - student pocházející ze slavné rodiny Szaniawských erbu Junosza z Velkoknížectví litevského. Titul bakaláře získal na právnické fakultě 27 . května 1709, titul mistra 4. července 1710. Během studií byl ubytován v konviktu sv. Bartoloměje. Podrobněji o něm viz s. 79.

Krzysztof Antoni Szembek - člen významné rodiny Szembeků, užíval vlastní erb. Studoval teologii a právo v Krakově a v Ř́mě, kdy získal titul doktora práv. Na filozofické 
fakultě pražské univerzity studoval už jako církevní hodnostář, 13. srpna 1699 získal titul mistra filozofie. Podrobněji o něm srov. s. 74-76.

Szymon Tenor - student pocházející z obce Kronowo. Studoval v akademickém roce 1644/1645 na filozofické fakultě.

Nikodem Turno - student pruského původu, člen řádu cisterciáků v klášteře v Olivě. V roce 1724 je uveden jako student právnické fakulty.

Verecundus Tuszyński - duchovní, titul bakaláře získal na filozofické fakultě 22. května 1656.

Andrzej Jakub Voigt - student pocházející z města Wschowa ve Velkopolsku. V roce 1719 je uveden jako student právnické fakulty.

Franciszek Bruno Weitzenmüller - student polského původu. V roce 1755 je uveden jako student právnické fakulty.

Piotr Ignacy Werner - student pruského původu z města Braniewo (Braunsberg). $\mathrm{V}$ roce 1656 je uveden jako student právnické fakulty.

Marcin Ambroży Wirdt - student pocházející z obce Święciechowa. Titul bakaláře získal na filozofické fakultě 13 . května 1641, titul mistra 4. srpna 1643. Během celé doby studia byl ubytován v semináři sv. Václava.

Michal Tomasz Korybut Wiśniowiecki - šestý volený polský král (1669-1673). V letech 1656-1660 studoval na filozofické a právnické fakultě. Náležel mezi př́ležitostné šlechtické studenty, kteří se přednášek neúčastnili pravidelně. Jako důkaz díků věnoval univerzitě cenný obraz svaté Kateřiny, jehož autorem byl Karel Škréta. Podrobněji srov. s. 66-73.

Gregorz Wojciech Wiśniowski - student šlechtického původu z obce Wiśniów v lublinském vojvodství, který užíval erb Prus. Titul mistra získal na filozofické fakultě 18. července 1697.

Michal Wojciech Witt - student pocházející z Varšavy. Titul bakaláře získal na filozofické fakultě 9 . května 1706, titul mistra 5. srpna 1706. Získal také titul bakaláře na teologické fakultě 6 . září 1707 . V době studií byl ubytován v konviktu sv. Bartoloměje.

Grzegorz Kazimierz Wojnarowski - student šlechtického původu erbu Strzemie. V roce 1672 je uveden jako student právnické fakulty.

Celestyn Würth - student pocházející z obce Święciechowa. Studoval na filozofické fakultě v akademickém roce 1644/1645. 
Marcin Ignacy Zahn - student pocházející z obce Święciechowa, mladší bratr Jana Karola Zahna. Titul bakaláře získal na filozofické fakultě 23. června 1655, titul mistra 6. záríi 1656. Byl také posluchačem teologické fakulty. Podrobněji o něm srov. s 79-80.

Jan Karol Zahn - student pocházející z obce Święciechowa, starší bratr Marcina Ignacyho Zahna. Během sedmiletého studia získal titul bakaláŕe filozofie (13. června 1652), bakaláře teologie a licenciáta práv. V Praze byl 15. června 1661 také vysvěcen na kaplana. Podrobněji o něm srov. s. 79-80.

Andrzej Zakrzewski - student šlechtického původu, představitel mladší linie velkopolského rodu Zakrzewských erbu Wyssogota; starší bratr Ignacyho Zakrzewského. Studoval na filozofické fakultě v akademickém roce 1647/1648, ale opustil Prahu, aby se vydal na vojenskou výpravu proti Tatarům.

Ignacy Zakrzewski - student šlechtického původu, představitel mladší linie velkopolského rodu Zakrzewských erbu Wyssogota; mladší bratr Andrzeje Zakrzewského. Studoval na filozofické fakultě v akademickém roce 1647/1648, ale byl evakuován z Prahy z důvodu obléhání města Švédy. Podrobněji o něm srov. s. 79.

Krzysztof Zianowski - notář z města Radom. V roce 1686 je uváděn jako student právnické fakulty.

Přkeklad Marek Ďurčanský

ROBERT T. TOMCZAK

\section{Studenten aus der polnisch-litauischen Union (Rzeczpospolita) an der Prager Universität im 17. und 18. Jahrhundert}

\section{ZUSAMMENFASSUNG}

Auslandsstudienreisen junger Menschen aus der polnisch-litauischen Union (Rzeczpospolita) im 17. und 18. Jahrhundert ist eines der häufigen Themen in der polnischen Historiographie. Bisher standen im Vordergrund des Interesses Polen, die an Schulen in Frankreich, Holland, Italien oder Deutschland studierten, weil die dortigen akademischen Zentren aus der Sicht des polnischen Adels und reicher Bürgerschichten am attraktivsten waren. Als nicht weniger interessant jedoch erweisen sich auch die akademischen Kontakte Polens mit seinen Nachbarländern, beispielsweise mit den böhmischen Ländern. Will man die Problematik von Studien der polnischen Jugend in Böhmen untersuchen, so muss man die Kontakte von Polen mit der in diesem Teil Europas ältesten Universität: der Prager Universität, berücksichtigen. Obgleich dieses akademische Zentrum im Rahmen einer Intellektuellenkarte des frühneuzeitlichen Europas als konservativ und provinziell charakterisiert werden kann, ebenso wie die Hochschulen in Polen und Litauen, so strahlte es doch angesichts seiner Traditionen und geografischen Lage für einen Teil der polnischen Jugend weiterhin eine beträchtliche Anziehungskraft aus.

Im Laufe des 17. und 18. Jahrhunderts besuchten die Hörsäle der Prager Universität an die hundert namentlich bekannte und in den Quellen (Matrikeln, Alben und Universitätsdrucken) erfasste Studenten, die aus den Ländern der polnisch-litauischen Union stammten, d.h. aus dem Königreich Polen, dem Großfürstentum Litauen, dem Königlichen Preußen und dem Herzoglichen Preußen (bis 1657). Sie kamen vor allem aus Gebieten, die in der geografischen Nähe Prags lagen, konkret aus Großpolen (31\%) und Kleinpolen (6\%). Die anderen Regionen waren 
wie folgt vertreten: das Königliche Preußen (24\%), das Großfürstentum Litauen (5\%), Masurien (7\%), Kleinrussland (4\%), Lublin (4\%), Podlachien (2\%), ferner die Regionen Schieratz (Sieradze; 1\%), Rawa (1\%) und Kujawien (Kujavy; 1\%). Bei 15\% der Studenten ließ sich ihre territoriale Herkunft nicht feststellen. Diese Jugendlichen repräsentierten den Adel (40\%) bzw. den an der Prager Universität zahlreicher vertretenen stadtbürgerlichen Stand (51\%). Bei 9\% der Studenten ließ sich ihre soziale Zuordnung nicht ermitteln. Von den Studenten adliger Herkunft können bekannte historische Persönlichkeiten erwähnt werden, die ihren Bildungsgang in Prag absolvierten und danach in der Polnisch-Litauischen Union hohe Ämter bekleideten, darunter beispielsweise der spätere sechste gewählte König Michal Korybut Wiśniowiecki (Michael I.), der Primas von Polen und Litauen Krzysztof Antoni Szembek oder Hieronymus Roth, Gegner des Kurfürsten im Herzoglichen Preußen.

Die in Prag studierenden Polen verwirklichten die Modelle der Stände und Erziehungsideale der altpolnischen Epoche, allerdings in kleinerem Maßstab, denn Prag lag in Grenznähe zum polnisch-litauischen Staat. Die mit dem Studium an der Prager Universität verbundenen Kosten fielen somit geringer aus und waren auch für die ärmeren Schichten von Adel und Bürgertum annehmbar, deren Angehörige vor allem in Prag studierten. Entfernung, Reiseund Aufenthaltskosten sowie der katholische Charakter der Universität waren das Hauptkriterium, nach welchem sich die polnischen Jugendlichen richteten, als sie sich als Stätte ihrer Ausbildung das akademische Milieu Prags wählten. Die meisten von ihnen studierten an der philosophischen Fakultät, gefolgt von der juristischen, medizinischen und theologischen Fakultät, doch besuchten einige Studenten auch zwei oder sogar drei Fakultäten.

Nach Abschluss des Studiums an der Prager Universität, der nur teilweise mit dem Erwerb akademischer Titel verbunden war, verwirklichten die jungen Absolventen im Rahmen ihrer gesellschaftlichen Stellung eine politische, kirchliche oder Ämterlaufbahn. Adlige wurden Landes- oder Staatsbeamte, Großgrundbesitzer und hohe kirchliche Würdenträger, Stadtbürger hingegen Handwerker, städtische Beamte oder niedriger gestellte Kleriker. Aus diesem Grunde lässt sich nicht beurteilen, in welchem Maße das Studium in Prag im späteren Leben der polnischen Studenten von Nutzen war und welches Gewicht die errungenen akademischen Grade für sie hatten. Ihre weitere Tätigkeit lässt sich für die gesellschaftspolitische Struktur des polnisch-litauischen Gemeinwesens, für das eine starke Abstufung der Gesellschaft und fehlende Prinzipien eines gleichberechtigten Miteinanders im Rahmen des Staates charakteristisch waren, als typisch bezeichnen.

Deutsche Übersetzung Wolf B. Oerter

\author{
Robert T. Tomczak \\ Wydziat Historyczny, Uniwersytet im. Adama Mickiewicza w Poznaniu \\ robertomczak@yahoo.com
}

